This PDF is a selection from a published volume from the National Bureau of Economic Research

Volume Title: Measuring Capital in the New Economy

Volume Author/Editor: Carol Corrado, John Haltiwanger and Dan Sichel, editors

Volume Publisher: University of Chicago Press

Volume ISBN: 0-226-11612-3

Volume URL: http://www.nber.org/books/corr05-1

Conference Date: April 26-27, 2002

Publication Date: August 2005

Title: Growth of U.S. Industries and Investments in Information Technology and Higher Education

Author: Dale W. Jorgenson, Mun S. Ho, Kevin J. Stiroh

URL: http://www.nber.org/chapters/c10627

Chapter pages in book: (403 - 478) 


\title{
Growth of U.S. Industries and Investments in Information Technology and Higher Education
}

\author{
Dale W. Jorgenson, Mun S. Ho, and Kevin J. Stiroh
}

\subsection{Introduction}

Our objective in this paper is to quantify the sources of U.S. economic growth for 1977-2000 using data for individual industries. This "bottomup" approach complements the "top-down" analysis approach employed in our earlier work. ${ }^{1}$ Industry-level data enable us to trace the sources of U.S. economic growth to their industry origins, to isolate and analyze the industries that produce information technology (IT), and to assess the relative importance of total factor productivity growth and factor accumulation at both industry and economywide levels. ${ }^{2}$

Productivity growth in IT-producing industries has steadily risen in importance, generating a relentless decline in the prices of IT equipment and software. This decline in IT prices is rooted in developments in technology

Dale W. Jorgenson is the Samuel W. Morris University Professor in the Department of Economics at Harvard University. Mun S. Ho is a visiting scholar at Resources for the Future. Kevin J. Stiroh is assistant vice president in the Banking Studies Function at the Federal Reserve Bank of New York.

We are grateful to Jon Samuels for excellent research assistance and Conference on Research in Income and Wealth participants, especially our discussant Michael Harper, the editors, and two anonymous referees for helpful comments and useful suggestions for the revisions of this paper. Many have generously provided data and advice-Jay Berman, Charles Bowman, Carl Chentrens, James Franklin, Tom Hale, Tom Nardone and Larry Rosenblum, Kurt Kunze, Eldon Ball, Mike Dove, and Scott Segerman. The views expressed are those of the authors and do not necessarily reflect those of the Federal Reserve System or the Federal Reserve Bank of New York.

1. See Jorgenson and Stiroh (2000), Jorgenson (2001), and Jorgenson, Ho, and Stiroh (2002), as well as Baily (2002), Congressional Budget Office (2002), Council of Economic Advisors (2002), Gordon (2002), McKinsey Global Institute (2001), Oliner and Sichel (2000, 2002), and Whelan (2002).

2. Baily and Lawrence (2001) and Stiroh (2002) provide industry comparisons that examine the role of IT, and Brynjolffson and Hitt (2000) survey firm-level results. 
that are widely understood by technologists and economists, particularly the continuous improvement in the performance-price ratio of semiconductors captured by Moore's Law (Jorgenson 2001). Information technology has reduced the cost and improved the performance of products and services embraced by U.S. businesses, households, and governments. The enhanced role of investment in IT is a conspicuous feature of the U.S. economy, and a growth revival is under way in many important IT-using industries.

The key IT-producing industries are computers, communications equipment, semiconductors, and software. These are below the usual two-digit Standard Industrial Classification (SIC) level used in other studies, and we have created detailed data for them in order to characterize IT production as precisely as possible. Industrial Machinery and Equipment (SIC 35), for example, includes Computers and Office Equipment (SIC 357), while Electronic and Electrical Equipment (SIC 36) contains Communications Equipment (SIC 366) and Electronic Components (SIC 367), mainly semiconductors. Business Services (SIC 73) includes Computer Services (SIC 737), primarily software. This breakdown enables us to quantify the impact of IT production on the U.S. economy more accurately and represents a substantial advantage over earlier studies using the broader industry aggregates.

The mechanisms for diffusion of advances in IT are twofold. First, advances in semiconductors generate continuing price reductions for a given level of performance. These price reductions drive demands for intermediate inputs in semiconductor-using industries such as computers, communications equipment, and a host of others. Second, the industries that use semiconductors as inputs generate further price declines that drive investments in IT equipment like computers and telecommunications equipment. Advances in equipment production augment the downward pressure on prices, steadily redirecting the rising IT investment flow toward its most productive uses. ${ }^{3}$

On the labor side, college-educated workers are often identified as "knowledge workers" who make use of IT equipment and software, so we have divided labor input between college and noncollege workers. Obviously, not every knowledge worker is a college graduate, nor is every college graduate a knowledge worker. A second issue is that while investments in IT take place within the industries we have identified, investments in higher education are undertaken by future college-educated workers and precede employment of these workers, sometimes by a considerable period of time. We measure the flow of human capital services from collegeeducated workers, but not the accumulation of the stock of this capital that takes place in colleges and universities.

3. Models of the interactions among semiconductor, computer, and other industries are presented by Dulberger (1993), Triplett (1996), and Oliner and Sichel (2000). 
Our empirical results show that the appropriate framework for analyzing the impact of IT is a production possibility frontier that includes outputs of IT-producing industries, as well as inputs of IT capital services, rather than the usual aggregate production function. Two advantages of this framework are that we incorporate detailed data from individual industries, including the IT-producing industries, and that the prices of IT outputs and inputs are linked through the prices of IT capital services. Finally, we report detailed results for industry production accounts and demonstrate the critical importance of investments in IT capital and higher education across U.S. industries.

Table 11.1 summarizes the results of a growth-accounting decomposition of aggregate value added in the U.S. economy using a production possibility frontier that is generated directly from industry-level data. This decomposition is based on annual observations for the period 1977-2000, as well as the subperiods 1977-90, 1990-95, and 1995-2000. While these time periods are conventional, a word about the choice of the periods is useful. The first year in our data set is 1977, and the slow growth associated with the energy crisis of the 1970s is readily apparent in the data. The end of the last recession in our sample is 1991, and 1995 marks the surge in economic growth and jump in the rate of decline of IT prices.

Results show that recent resurgence of the U.S. economy raised the growth rate of value added by 1.85 percentage points when 1995-2000 is compared to 1990-95. Capital input contributes 1.02 percentage points to the post-1995 revival, with a little more than half of this due to the surge in IT investment. Labor input contributes 0.44 percentage points to the growth resurgence. College-educated workers contribute about a third of a percentage point, while noncollege workers add another tenth of a percentage point to the growth resurgence. Faster growth in total factor productivity contributes the remaining 0.40 percentage points. These bottom-up results are quite comparable to the top-down estimates mentioned earlier.

The worth of underlying industry detail, however, is also readily apparent in table 11.1, which documents the rising contributions of ITproducing industries to U.S. economic growth. These industries have been steadily growing in importance, and their contribution to growth jumps by 75 percent after 1995. The contribution of IT inputs into production more than doubles after 1995 as the pace of IT price declines accelerated. In response to these price declines, firms, households, and governments accumulate IT equipment and software much more rapidly than other forms of capital. Non-IT capital, however, still predominates in the contribution of capital input and remains the most important source of U.S. economic growth throughout the period 1977-2000.

The contribution of labor input is next in importance as a source of U.S. economic growth and plays a vital role in the resurgence of the American economy after 1995. The contribution of college-educated workers domi- 


\begin{tabular}{|c|c|c|c|c|c|}
\hline \multicolumn{6}{|c|}{ Contributions } \\
\hline Value-added & 3.08 & 2.93 & 2.35 & 4.20 & 1.85 \\
\hline IT & 0.43 & 0.33 & 0.40 & 0.70 & 0.31 \\
\hline Non-IT & 2.65 & 2.60 & 1.95 & 3.50 & 1.55 \\
\hline Capital input & 1.74 & 1.73 & 1.25 & 2.27 & 1.02 \\
\hline IT & 0.65 & 0.52 & 0.55 & 1.11 & 0.57 \\
\hline Non-IT & 1.09 & 1.22 & 0.71 & 1.15 & 0.45 \\
\hline Labor input & 1.19 & 1.27 & 0.86 & 1.30 & 0.44 \\
\hline College & 0.72 & 0.84 & 0.38 & 0.72 & 0.34 \\
\hline Non-college & 0.48 & 0.43 & 0.49 & 0.59 & 0.10 \\
\hline Aggregate TFP & 0.14 & -0.08 & 0.23 & 0.63 & 0.40 \\
\hline \multicolumn{6}{|c|}{ Addendum } \\
\hline Contribution of capital quality & 0.78 & 0.75 & 0.53 & 1.13 & 0.61 \\
\hline Contribution of capital stock & 0.96 & 0.98 & 0.73 & 1.13 & 0.41 \\
\hline Contribution of labor quality & 0.22 & 0.24 & 0.24 & 0.17 & -0.06 \\
\hline Contribution of labor hours & 0.97 & 1.03 & 0.63 & 1.13 & 0.51 \\
\hline \multicolumn{6}{|c|}{ Growth rates } \\
\hline Value-added & 3.08 & 2.93 & 2.35 & 4.20 & 1.85 \\
\hline IT & 17.97 & 17.01 & 16.08 & 22.37 & 6.29 \\
\hline Non-IT & 2.71 & 2.64 & 1.99 & 3.60 & 1.61 \\
\hline Capital input & 4.12 & 4.11 & 2.99 & 5.25 & 2.26 \\
\hline IT & 16.22 & 16.89 & 11.43 & 19.28 & 7.86 \\
\hline Non-IT & 2.85 & 3.12 & 1.91 & 3.09 & 1.18 \\
\hline Labor input & 2.07 & 2.21 & 1.47 & 2.30 & 0.82 \\
\hline College & 3.82 & 4.83 & 1.73 & 3.26 & 1.53 \\
\hline Non-college & 1.30 & 1.13 & 1.33 & 1.70 & 0.37 \\
\hline
\end{tabular}

Notes: All figures are average annual percentages. The contribution of an output or input is the growth rate multiplied by the average value share. IT value added includes production in SIC \#357, \#366, \#367, and \#737. IT capital input includes computer hardware, computer software, and telecommunications equipment.

nates the growth of labor input during the period 1977-2000, even though these workers are less numerous than noncollege workers. This reflects the facts that college-educated workers have higher marginal products on average, as can be seen in the college wage premium, and that the number of college-educated workers has been growing more rapidly than that of noncollege workers. Both college and noncollege workers, however, contribute to the growth revival after 1995. As the unemployment rate fell in the late 1990s, workers with a wide variety of levels of education and experience entered the ranks of the employed labor force.

Finally, growth in total factor productivity (TFP) is the smallest of the three proximate sources of U.S. economic growth-capital input, labor input, and TFP. In fact, TFP growth essentially disappears during 1977-90. 
During the past decade, TFP growth revives modestly during the subperiod 1990-95 and accelerates considerably after 1995.

As an addendum to table 11.1, we have divided the contribution of capital input between the contributions of capital stock and capital quality. The growth of capital quality, defined as the ratio of capital input to capital stock, reflects the rise in the relative importance of IT equipment and other forms of capital with higher marginal products and higher capital service prices. Capital stock fails to capture these differences in marginal products and has been superseded by a measure of capital input, as recommended in recent Organization for Economic Cooperation and Development (OECD) manuals on measuring capital (Blades 2001) and productivity (Schreyer 2001).

Similarly, we have divided the contribution of labor input between the contributions of hours worked and labor quality. The growth of labor quality, defined as the ratio of labor input to hours worked, captures the rise in the relative importance of college-educated workers and other workers with higher marginal products and higher compensation per hour. Hours worked fails to capture these differences in marginal products and has been superseded by a measure of labor input, as recommended in the United Nations' (1993) System of National Accounts 1993 and Schreyer's (2001) OECD Productivity Manual.

Growth in value added is the sum of growth in hours and growth in average labor productivity (ALP). Table 11.2 presents this decomposition for the period 1977-2000 and shows that hours worked predominate, rising at 1.68 percent per year compared to ALP growth of 1.39 percent per year. Growth of ALP depends on capital deepening, labor quality growth, and the growth of TFP, and we have divided capital deepening between IT and non-IT capital inputs and labor quality among college-educated and noncollege workers and the reallocation of hours between these two categories of workers.

The results reveal that the slow growth of labor productivity in the 1970s and 1980s is due to a slump in capital deepening. The growth rate of ALP rises only slightly during the first half of the 1990s as capital deepening continues to slump, labor quality growth remains unchanged, and TFP growth experiences a modest revival. A substantial slowdown in the growth of hours worked generates a further slide in output growth in the early period.

Accelerating growth during 1995-2000 reflects a surge in the growth of hours worked of 0.93 percentage points and a similar rise in ALP growth. Table 11.2 shows that this reflects an increase in capital deepening of 0.60 percentage points, two-thirds of the increase in ALP growth, with most of this, 0.51 percentage points, due to a sharp jump in IT-capital deepening after 1995 . The 0.40 percentage point increase in TFP growth is partly offset by a drop in the growth rate of labor quality of 0.06 points. This can 
Table 11.2

Decomposition of aggregate labor productivity and TFP

$1995-2000$

$1977-2000 \quad 1977-90 \quad 1990-95 \quad 1995-2000$ less 1990-95

\begin{tabular}{|c|c|c|c|c|c|}
\hline \multicolumn{6}{|c|}{ Contributions } \\
\hline Average labor productivity & 1.39 & 1.13 & 1.28 & 2.21 & 0.93 \\
\hline Capital deepening & 1.03 & 0.97 & 0.81 & 1.40 & 0.60 \\
\hline IT & 0.58 & 0.46 & 0.49 & 1.00 & 0.51 \\
\hline Non-IT & 0.45 & 0.51 & 0.32 & 0.41 & 0.09 \\
\hline Labor quality & 0.22 & 0.24 & 0.24 & 0.17 & -0.06 \\
\hline College & 0.02 & 0.03 & -0.01 & 0.01 & 0.02 \\
\hline Non-college & 0.08 & 0.04 & 0.18 & 0.06 & -0.13 \\
\hline Reallocation of hours & 0.13 & 0.16 & 0.06 & 0.10 & 0.04 \\
\hline Aggregate TFP & 0.14 & -0.08 & 0.23 & 0.63 & 0.40 \\
\hline \multicolumn{6}{|c|}{ Productivity and reallocations } \\
\hline Aggregate TFP & 0.14 & -0.08 & 0.23 & 0.63 & 0.40 \\
\hline Reallocation of capital input & 0.02 & 0.03 & -0.02 & 0.03 & 0.05 \\
\hline IT & -0.01 & 0.00 & -0.03 & -0.02 & 0.01 \\
\hline Non-IT & 0.03 & 0.03 & 0.01 & 0.05 & 0.04 \\
\hline Reallocation of labor input & -0.04 & -0.02 & -0.09 & -0.03 & 0.06 \\
\hline College & -0.01 & -0.01 & -0.01 & -0.01 & 0.00 \\
\hline Non-college & -0.03 & -0.01 & -0.08 & -0.03 & 0.05 \\
\hline Domar-weighted productivity & 0.16 & -0.09 & 0.35 & 0.63 & 0.28 \\
\hline IT & 0.27 & 0.21 & 0.30 & 0.41 & 0.11 \\
\hline Non-IT & -0.11 & -0.30 & 0.05 & 0.22 & 0.17 \\
\hline \multicolumn{6}{|c|}{ Addendum } \\
\hline \multicolumn{6}{|l|}{$\begin{array}{l}\text { Aggregate production function } \\
\text { value-added }\end{array}$} \\
\hline value-added & 3.11 & 2.75 & 2.12 & 5.04 & 2.92 \\
\hline Reallocation of value-added & 0.04 & -0.17 & -0.22 & 0.84 & 1.07 \\
\hline Hours growth & 1.68 & 1.80 & 1.07 & 1.99 & 0.93 \\
\hline
\end{tabular}

Notes: All figures are average annual percentages. The contribution of an output or input is the growth rate multiplied by the average value share. IT value added includes production in SIC \#357, \#366, \#367, and \#737. IT in capital input includes computer hardware, computer software, and telecommunications equipment. Aggregate TFP is from the production possibility frontier and Domar-weighted productivity is from aggregation across sectors (defined in text).

be traced to a decline in quality growth for noncollege workers, associated with the surge in employment after 1995.

Table 11.2 also divides growth in TFP into components associated with IT-producing and non-IT-producing industries. As expected, this reveals a gradual rise in the contribution of IT-producing industries that has continued throughout our sample. Growth of TFP in non-IT industries is small and negative on average, which reflects the offsetting effects of industries with positive and negative TFP growth over this period. Since 1995, however, non-IT TFP growth has accelerated, which may reflect investments in intangible assets like unmeasured human capital, workplace practices, new business models, structural capital, and organizational cap- 
ital. ${ }^{4}$ Two additional components of aggregate TFP growth that capture differences in marginal products of inputs in different industries are reallocations of capital and labor inputs among industries. For the period as a whole these reallocations are relatively small, but reallocations of labor input fluctuate considerably.

Finally, as an addendum in table 11.2, we have compared growth in economywide value added estimated from two industry-level aggregation approaches - the production possibility frontier and the aggregate production function. The difference between these two measures is the reallocation of value added, which, as we will discuss in more detail, captures differences in the price of a unit of value added. If the production possibility frontier reduces to an aggregate production function, this price must be the same for all industries. While the differences were modest in size for the period 1948-79 covered by Jorgenson, Gollop, and Fraumeni (1987), the results in table 11.2 reveal that these differences are no longer small. For the period 1995-2000, the reallocation of value added reaches nearly a full percentage point.

The wide gap between the production possibility frontier and the aggregate production function can largely be attributed to the more detailed classification of IT-producing industries employed in our study. Differences in the growth of value-added prices between these industries and non-IT industries create a fixed-weight bias. ${ }^{5}$ This divergence shows the critical importance of accounting for relative price changes through an index number approach like that currently utilized in the U.S. national income and product accounts (NIPAs). We conclude that the production possibility frontier provides a more appropriate measure of aggregate output when using industry data and has superseded the aggregate production function.

The remainder of the paper is organized as follows. Section 11.2 presents our methodology for measuring output and intermediate inputs. The most important feature is a consistent time series of interindustry transactions table that allows us to allocate the sources of U.S. economic growth among industries. In section 11.3 we outline our methods for measuring capital input. Constant quality price indexes for information technology equipment are essential for separating the change in performance of this equipment from the change in price for a given level of performance. The cost of capital is the key concept for capturing the economic impact of information technology prices. Section 11.4 outlines our methods for measuring labor input. These incorporate differences in hours worked and wages for workers who differ in age, sex, and, most important, educational attainment.

4. See Abowd et al. (chap. 5 in this volume), Lev and Radhakrishman (chap. 3 in this volume), and Black and Lynch (chap. 6 in this volume) for overviews of these topics.

5 . The aggregate production function uses fixed weights because the value-added prices are assumed to be the same. 
In section 11.5 we outline a framework for aggregating output, capital, labor, and intermediate inputs, and productivity over industries. This framework was introduced by Jorgenson, Gollop, and Fraumeni (1987). A key role is played by a weighting scheme proposed by Domar (1961), based on the relative importance of each industry in value added, as well as the relative importance of value added in the industry's output. The Domar weighting scheme captures the impact of sources of growth at the industry level, both in the industry where growth occurs and in the industries that purchase the output of this industry.

In section 11.6 we present an analysis of the sources of U.S. economic growth at the industry level. The contributions of capital and labor inputs and gains in economywide TFP presented in tables 11.1 and 11.2 reflect the evolution of the production structure of all industries in the U.S. economy. We aggregate over industries in order to show how changes in the production structure at the industry level cumulate to determine economywide economic growth. We focus special attention on the role of TFP growth in the IT-producing industries, investments in IT equipment and software, and services of the human capital of knowledge workers. Section 11.7 concludes the paper.

\subsection{Measuring Output, Intermediate Input, and Value Added}

This section describes our methodology for measuring industry outputs, intermediate inputs, and value added. This methodology uses a time series of input-output (I-O) tables and was introduced by Jorgenson, Gollop, and Fraumeni (1987, chap. 5). The results were extended and updated by Jorgenson (1995b). Here we describe the further revisions of these studies.

\subsubsection{Notation}

$Y_{j} \quad$ quantity of output of industry $j$

$P_{Y, j} \quad$ price of output to producer in industry $j$

$P_{Y T, i} \quad$ price of output to purchasers from industry $j$

$X_{i, j} \quad$ quantity of input $i$ into industry $j$

$P_{i}^{X} \quad$ price of commodity $i$ to buyers

$X_{j} \quad$ index of total intermediate input into industry $j$

$P_{X, j} \quad$ price of total intermediate input into industry $j$

$P_{K, j} \quad$ price of total capital input to industry $j$

$P_{L, j} \quad$ price of total labor input to industry $j$

$v$ value shares

$Y C_{i} \quad$ quantity of domestically produced commodity $i$

$P_{Y C, i}$ price of domestically produced commodity $i$

$m_{i} \quad$ quantity of imports of commodity $I$

$P_{m, i} \quad$ price of imported commodity $i$ 
$Y S_{i} \quad$ quantity of total supply of commodity $i$

$M_{j, i} \quad$ Make matrix; value of commodity $i$ made by industry $j$

\subsubsection{Methodology}

We assume that the production function for industry $j$ has $M$ distinct intermediate inputs and that the function is separable in these inputs, so that

$$
Y_{j}=f\left(K_{j}, L_{j}, X_{j}, T\right) ; \quad X_{j}=X\left(X_{1, j}, X_{2, j}, \ldots X_{M, j}\right),
$$

where there are $M=44$ commodities corresponding to the primary products of the industries listed in table 11.3. ${ }^{6}$

Under the assumptions of constant returns to scale and competitive markets, the value of output is equal to the value of all inputs (capital, labor, and intermediate):

$$
P_{Y, j} Y_{j}=P_{K, j} K_{j}+P_{L, j} L_{j}+\sum_{i} P_{i}^{X} X_{i, j},
$$

where we assume that the price of intermediate input $P_{i}^{X}$ of commodity $i$ is the same for all purchasing sectors.

We define the quantity of intermediate input as a Tornqvist index of its components:

$$
\Delta \ln X_{j}=\sum_{i} \bar{v}_{i, j} \Delta \ln X_{i, j},
$$

where the $\bar{v}_{i, j}$ weights are the average, two-period shares of the components in the value of intermediate input.

The price index of intermediate input $P_{X, j}$ is equal to the value of intermediate input, divided by the quantity index $X_{j}$. Note that this price is specific to industry $j$, even if the prices of the component inputs are the same for all industries because the shares of the components differ among industries. $^{7}$

We require the concept of industry value added for aggregation over sectors in section 11.6. Assuming that the production function is separable in intermediate input and value added, we define industry value added $V_{j} \mathrm{im}-$ plicitly from the equation

$$
\Delta \ln Y_{j}=\left(1-\bar{v}_{v, j}\right) \Delta \ln X_{j}+\bar{v}_{v, j} \Delta \ln V_{j},
$$

6. We distinguish forty-four separate inputs. Each of these is an aggregate of many subcommodities, classified at a finer level of detail in the I-O accounts. Each industry purchases a basket of these intermediate inputs. If we were to construct the price of the basket from prices of the subcommodities, we would obtain a different price index for each purchasing industry. Our assumption is that all industries face the same price of intermediate input $i$.

7. The same subscript $i$ is used in the numerator and denominator of equation (4) to avoid the proliferation of symbols; the different references should be obvious. This applies to similar expressions throughout the paper. 
where the $\bar{v}_{v, j}$ weights are the two-period average shares of value added in gross output.

Value added in nominal terms is $P_{V, j} V_{j}=P_{K, j} K_{j}+P_{L, j} L_{j}$. The price of value added, $P_{V, j}$, is derived by dividing this nominal value by the quantity index from equation (4).

In order to identify the impact of information technology, we isolate the industries that produce IT. In particular, we divide Industrial Machinery and Equipment (SIC 35) into Computers (SIC 357) and Machinery, excluding Computers. Similarly, we divide Electronic and Electrical Equipment (SIC 36) into Electronic Components (SIC 367, which includes semiconductors, SIC 3674), Communications Equipment (SIC 366), and Other Electrical Machinery. Finally, we divide Business Services (SIC 73) into Computer Services (SIC 737, which includes software) and Other Business Services. This breakdown allows us to better identify and analyze the impact of IT production on the U.S. economy.

We derive both outputs and intermediate inputs from a time series of interindustry transactions tables. These tables consist of a Use table that allocates the use of each commodity among intermediate inputs and final demand categories and a Make table that allocates the output of each commodity among the industries that produce it. The output of a given commodity by all industries and the input of this commodity by all industries must be equal.

In the Use table, the $j$ th column represents industry $j$, and the $i$ th row represents commodity $i$. In nominal terms, the sum of the elements in column $j$ is the value of the industry's output. This is equal to the value of this output to the producer, plus taxes paid on this output by the purchaser $T_{j}$ :

$$
P_{Y T, j} Y_{j}=P_{Y, j} Y_{j}+T_{j},
$$

where the price received by the seller is $P_{Y, j}$ and the price paid by the purchaser is $P_{Y T, j}$.

An industry may produce several commodities, and a commodity may be produced by several industries. ${ }^{8}$ The value of the output of industry $j$ is equal to the value of all the commodities it produces:

$$
P_{Y T, j} Y_{j}=\sum_{i} M_{j, i}
$$

where $M_{j, i}$ is the value of commodity $i$ produced by $j$. This implies that

$$
V C_{i}=P_{Y C, i} Y C_{i}=\sum_{j} M_{j, i},
$$

where $Y C_{i}$ denotes the quantity of domestically produced commodity $i$ and $V C_{i}$ the value. 
We assume that each commodity is an aggregate of the quantities produced in various industries and the price of the $i$ th commodity $P_{Y C, i}$ is given by

$$
\ln P_{Y C, i}=\sum_{j} \frac{M_{j, i}}{V C_{i}} \ln P_{Y T, j} .
$$

The Use table also includes sales to final demand. This is broken down into the familiar categories of personal consumption expenditures, gross private domestic investment, government purchases, exports, and imports $(c, i, g, x, m)$. The sum of the elements in row $i$ of the Use table is the value of all deliveries of the $i$ th commodity to intermediate and final demand. Thus, the supply-demand balance for commodity $i$ in value terms is

$$
P_{Y C, i} Y C_{i}=\sum P_{i}^{X} X_{i}+P_{i}^{X}\left(c_{i}+i_{i}+g_{i}+x_{i}\right)-P_{m, i} m_{i} .
$$

We can rewrite this as the total supply from domestic suppliers and imports, which equals total demand:

$$
P_{Y C, i} Y C_{i}+P_{m, i} m_{i}=\sum P_{i}^{X} X_{i}+P_{i}^{X}\left(c_{i}+i_{i}+g_{i}+x_{i}\right) .
$$

We assume that all buyers purchase the same basket of commodity $i$ that is, the same share of the imported variety. The quantity of the total supply of commodity $i, Y S_{i}$, is assumed to be a translog index of the two varieties, and the price is defined to make the value identity hold:

$$
\begin{gathered}
\Delta \ln Y S_{i}=\bar{v}_{C} \Delta \ln Y C_{i}+\bar{v}_{m} \Delta \ln m_{i} \\
P_{i}^{X} Y S_{i}=P_{Y C, i} Y C_{i}+P_{m, i} m_{i}
\end{gathered}
$$

Note that this price $P_{i}^{X}$ is the price paid by producers for their input in equation (2). This completes our interindustry accounting system.

\subsubsection{Data}

We next describe the sources and methods for construction of our system of interindustry accounts. The starting point is the official benchmark U.S. Inter-Industry Transactions tables produced by the Bureau of Economic Analysis (BEA). These are available for the years 1977, 1982, 1987, and 1992. ${ }^{9}$ The Office of Employment Projections of the Bureau of Labor Statistics (BLS) uses these benchmark tables to generate a time series of interindustry transactions tables for 1983-2000. An earlier version covered the period 1977-95. ${ }^{10}$ These data are combined with the time series of industry outputs, also from the Office of Employment Projections, giving us

9. The latest tables are described in Survey of Current Business, November 1997, p. 36.

10. We are grateful to Charles Bowman, Carl Chentrens, and James Franklin of the BLS for providing these data and patiently explaining the details. The data are available on the Office of Employment Projections website at http://www.bls.gov/emp/. 
both values and prices. The major difference between the BEA 1992 benchmark table and the BLS I-O tables is the treatment of software; the BLS includes an explicit estimate of software for each sector.

We consolidate and reorganize the BLS interindustry transactions tables from 192 industries to 44 industries. ${ }^{11}$ The major differences are the following: (a) we treat owner-occupied housing as a direct purchase of capital input by households, rather than a purchase of housing services from the real estate industry; (b) we consolidate privately owned electric utilities with publicly owned utilities in SIC 32, leaving a government enterprises sector that does not include electric utilities; (c) the government industry is simplified by consolidating government labor and capital services into the final demand column for government purchases; (d) we impute the service flow from consumers' durable assets to obtain the consumption of these capital services and treat these as a direct purchase of capital services by households; (e) we treat nonprofit producers symmetrically with the other producers - our accounts are thus broader in scope than those limited to for-profit business sectors; (f) we have adjusted the tables for 1998-2000 to match the GDP given in the August 2001 Survey of Current Business; the BLS series are based on a previous revision of the NIPAs.

For the period 1977-82, prior to the beginning of the current BLS time series of interindustry transactions tables, we use a previous version of these BLS tables for 1977-95, based on the 1987 benchmark tables. We consolidate the earlier tables in a similar manner and link them to the current tables for 1983-2000. To make them comparable, we adjust the 197782 tables to the new values of industry output produced by the BLS Office of Employment Projections, using the method of iterative proportional fitting discussed by Jorgenson, Gollop, and Fraumeni (1987, pp. 72-75). Sectors such as construction, oil mining, and electric utilities are quite different between these two versions, and the previous series are adjusted to match the current one. Our final set of matrices for 1977-2000 is thus consistent with the latest estimates of industry output from the BLS and the annual update of GDP published by the BEA in 2001 (Survey of Current Business, August 2001).

The total of all entries in each column of the Use table is consistent with the BLS time series for Industry Output and Employment. ${ }^{12}$ This data set provides the value of output, the price of output, and employment for the same industries for the period 1977-2000. The exceptions to this are Communications Equipment (BLS industry 53) and Computer and Data Processing Services (BLS industry 147), where we replace the BLS prices with

11. The aggregation process involves reallocating special sectors like scrap, rest of the world, inventory valuation adjustment, general government, and so on. These are reallocated to the forty-four sectors and final demand in accord with both Use and Make matrices.

12. Data were kindly provided by Jay Berman of the BLS. The data are available at http:// www.bls.gov/emp/empind2.htm. 
BEA prices that are adjusted for quality change. ${ }^{13}$ The prices received by producers are obtained by subtracting output taxes from the purchasers' prices.

The BLS I-O data set also includes the final demand categories- $-c, i, g$, $x, m$-in both current and constant prices. Using information on imports by commodities, we derive the price for imports $P_{m, i}$. We calculate a price index for the total supply of commodity $i$ using equation (11). Finally, we derive the prices and quantities of intermediate inputs. The value of input $i$ into industry $j$ is given by the Use matrix. The price $P_{i}^{X}$ has been calculated, as described above, so that we can derive the quantities of interindustry transactions $X_{i, j}$. From equation (3), we calculate the quantity of intermediate input for each industry.

A major drawback of the BLS time series is that value added is not divided among capital and labor compensation and indirect business taxes, as in the BEA benchmark tables. To remedy this deficiency we employ GDP by industry data produced by the BEA. ${ }^{14}$ These data give, for each industry, the components of gross product-compensation of employees, proprietors' income, corporate profits, indirect business taxes, etc. The value of labor input described in section 11.4 below is the sum of compensation of employees and our estimated value of self-employed labor compensation. The estimation of the value of capital input is described in section 11.3 below and includes property compensation, less the imputed value of self-employed labor compensation, plus certain property taxes. The remainder of GDP after subtracting the value of capital and labor compensation is equal to sales taxes, net of subsidies, $T_{j}$.

\subsubsection{Issues}

\section{Breakdown of Value Added}

A major issue is that the data on GDP by industry produced by BEA are not consistent with the data on value added in the benchmark interindustry transactions tables. We maintain the total of value added for each industry estimated in the BLS tables and allocate it in the same proportions as those in GDP by industry. This gives us values of capital income, labor income, and taxes $-P_{K, j} K_{j}, P_{L, j} L_{j}$, and $T_{j}$, respectively - that sum to the BLS values. The quantities of capital and labor input are those derived from the GDP by industry data or the census data described in sections 11.3 and 11.4 below. The prices of capital input and labor input are derived by dividing these estimated values by the quantities derived from GDP by industry.

13. Data are available from the "Gross Output by Detailed Industry" file on the BEA's website, http://www.bea.gov/bea/dn2/gpo.htm, and described in Lum and Moyer (2000).

14. These data are described in Lum and Moyer (2000). The data are available at http:// www.bea.gov/bea/dn2/gpo.htm. 


\section{Frequency of Interindustry Transactions Tables}

A second difficulty in constructing a time series of interindustry transactions tables is that the time series for GDP by industry, published annually, are not consistent with the benchmark interindustry transactions tables published every five years. The magnitude and sources of the discrepancies are discussed in BEA (1997).

\section{Consistency over Time}

The 1977 and 1982 benchmark tables are based on the 1972 SIC, while 1987 and 1992 tables are based on the 1987 SIC. Similarly, the annual GDP by industry data have a break in 1987. Data for GDP by industry are provided for both classifications in 1987, and we have adjusted the old classification to the new one, using the shares of each of the old industries in the new industries for 1987 . For the interindustry transactions tables we apply the method of iterative proportional fitting to the matrices based on the 1972 SIC, using industry outputs based on the 1987 SIC. Our estimates of industry output and commodity prices are based on the BLS industry output and import prices. We assume that all buyers pay the same price for each commodity, reflecting the absence of data on prices for different purchasers.

\subsubsection{Results}

A list of the industries included in our study is given in table 11.3, together with the definition of each industry in the SIC. Industries 6-24 comprise manufacturing, while Industries 25-41 make up services. We have subdivided government among government enterprises (excluding publicly owned electric utilities), public education, and general government (excluding public education). The remaining sectors are agriculture, three mining sectors, construction, and the household sector. Table 11.3 gives output, intermediate input, and value added for all forty-four industries in the year 2000. Households and general government have no intermediate inputs, so that output is equal to value-added.

Table 11.4 gives growth rates of output, intermediate input, and value added for all forty-four sectors for the period 1977-2000. Output growth is most rapid for the IT-producing industries-Computers, Communications, Electronic Components, and Computer Services. Growth of intermediate input is also most rapid for these sectors. Finance, Other Business Services, Communications, and Professional and Social Services - all intensive users of IT - comprise the next echelon of four industries in terms of output growth. The IT sectors also lead in growth of intermediate input, but Finance has a slight edge over Communications Equipment in the growth of value added.

Table 11.5 presents growth rates of output for all forty-four sectors for 


\begin{tabular}{|c|c|c|c|c|}
\hline Code/Industry name & Output & $\begin{array}{l}\text { Intermediate } \\
\text { input }\end{array}$ & $\begin{array}{l}\text { Value- } \\
\text { added }\end{array}$ & SIC code \\
\hline 1 Agriculture & 388,994 & 193,213 & 195,781 & $01,02,07-09$ \\
\hline 2 Non-energy mining & 32,824 & 16,711 & 16,113 & 10,14 \\
\hline 3 Coal mining & 23,081 & 8,907 & 14,175 & 12 \\
\hline 4 Oil and gas mining & 131,487 & 63,982 & 67,505 & 13 \\
\hline 5 Construction & 995,279 & 576,079 & 419,200 & $15-17$ \\
\hline 6 Lumber, wood, furniture & 203,714 & 121,015 & 82,699 & $24-25$ \\
\hline 7 Stone, clay, glass & 111,040 & 57,519 & 53,522 & 32 \\
\hline 8 Primary metal & 192,553 & 130,936 & 61,617 & 33 \\
\hline 9 Fabricated metal & 279,540 & 154,000 & 125,540 & 34 \\
\hline 10 Machinery, excl. computers & 329,307 & 173,745 & 155,561 & $35 \times 357$ \\
\hline 11 Computers and office & & & & \\
\hline equipment & 142,803 & 104,860 & 37,943 & 357 \\
\hline 12 Other electrical machinery & 147,945 & 86,083 & 61,862 & $36 \times 366-367$ \\
\hline 13 Communications equipment & 101,430 & 53,270 & 48,160 & 366 \\
\hline 14 Electronic components & 183,792 & 97,991 & 85,802 & 367 \\
\hline 15 Motor vehicles & 417,709 & 344,636 & 83,072 & 371 \\
\hline $\begin{array}{l}16 \text { Other transportation } \\
\text { equipment }\end{array}$ & 186,241 & 99,120 & 87,121 & $372-379$ \\
\hline 17 Instruments and & & & & \\
\hline miscellaneous mfg. & 236,815 & 109,769 & 127,046 & $38-39$ \\
\hline 18 Food and tobacco & 528,328 & 357,205 & 171,122 & $20-21$ \\
\hline 19 Textiles, apparel, leather & 156,160 & 97,780 & 58,380 & $22-23,31$ \\
\hline 20 Paper & 175,955 & 103,013 & 72,942 & 26 \\
\hline 21 Printing and publishing & 233,512 & 95,800 & 137,712 & 27 \\
\hline 22 Chemicals & 422,654 & 239,216 & 183,438 & 28 \\
\hline 23 Petroleum refining & 242,918 & 208,722 & 34,196 & 29 \\
\hline 24 Rubber and plastic & 170,270 & 92,810 & 77,459 & 30 \\
\hline 25 Transportation & 553,535 & 290,201 & 263,335 & $40-47$ \\
\hline 26 Communications & 430,330 & 199,302 & 231,027 & 48 \\
\hline 27 Electricity & 245,658 & 79,331 & 166,326 & $491, \% 493$ \\
\hline $28 \mathrm{Gas}$ & 81,196 & 54,775 & 26,421 & $492, \% 493,496$ \\
\hline 29 Wholesale trade & 836,346 & 301,544 & 534,801 & $50-51$ \\
\hline 30 Retail and eating & $1,132,266$ & 476,991 & 655,275 & $52-59$ \\
\hline 31 Finance & 915,355 & 385,906 & 529,449 & $60-62,67$ \\
\hline 32 Insurance & 341,940 & 191,689 & 150,251 & $63-64$ \\
\hline 33 Real estate (rental) & 829,689 & 191,795 & 637,894 & 65 \\
\hline 34 Computer services & 308,442 & 120,124 & 188,317 & 737 \\
\hline 35 Business svc., excl. computer & 476,667 & 118,796 & 357,871 & $73 \times 737$ \\
\hline 36 Health, private & 833,500 & 283,836 & 549,663 & $801-806$ \\
\hline 37 Legal & 167,952 & 49,533 & 118,418 & 81 \\
\hline 38 Education, private & 130,847 & 54,004 & 76,843 & 82 \\
\hline 39 Professional and social svcs. & 902,500 & 301,107 & 601,393 & $832-829$ \\
\hline 40 Other services & 716,988 & 330,525 & 386,463 & $\begin{array}{c}494-497,701-729, \\
750-799\end{array}$ \\
\hline 41 Government enterprises & 253,696 & 88,546 & 165,149 & \\
\hline 42 Household & $1,394,410$ & 0 & $1,394,410$ & 88 \\
\hline 43 Government, excl. education & 747,471 & 0 & 747,471 & \\
\hline 44 Government education & 400,312 & 0 & 400,312 & \\
\hline
\end{tabular}

Notes: All figures in millions of current dollars. \% indicates part of an SIC code. X indicates excludes SIC code. 


\begin{tabular}{|c|c|c|c|}
\hline Industry name & Output & Intermediate input & Value-added \\
\hline Agriculture & 2.40 & 0.73 & 4.74 \\
\hline Non-energy mining & 1.53 & 1.05 & 1.89 \\
\hline Coal mining & 1.89 & 1.25 & 2.88 \\
\hline Oil and gas mining & -0.32 & -0.12 & 0.12 \\
\hline Construction & 1.65 & 2.66 & 0.40 \\
\hline Lumber, wood, furniture & 2.00 & 1.91 & 2.21 \\
\hline Stone, clay, glass & 1.65 & 1.75 & 1.55 \\
\hline Primary metal & 0.22 & -0.38 & 1.61 \\
\hline Fabricated metal & 1.98 & 2.07 & 1.87 \\
\hline Machinery, excl. computers & 1.40 & 2.43 & 0.33 \\
\hline Computers and office equipment & 23.70 & 14.99 & 42.01 \\
\hline Other electrical machinery & 2.28 & 2.92 & 1.40 \\
\hline Communications equipment & 8.73 & 10.01 & 7.36 \\
\hline Electronic components & 18.15 & 11.02 & 25.44 \\
\hline Motor vehicles & 2.60 & 3.11 & 0.94 \\
\hline Other transportation equipment & 2.32 & 3.28 & 1.38 \\
\hline Instruments and miscellaneous mfg. & 3.25 & 4.51 & 2.23 \\
\hline Food and tobacco & 1.60 & 1.28 & 2.51 \\
\hline Textiles, apparel, leather & 0.33 & -0.33 & 1.49 \\
\hline Paper & 1.64 & 1.53 & 1.80 \\
\hline Printing and publishing & 2.06 & 2.42 & 1.73 \\
\hline Chemicals & 1.45 & 1.47 & 1.44 \\
\hline Petroleum refining & 0.47 & 1.23 & 1.26 \\
\hline Rubber and plastic & 3.61 & 2.37 & 5.23 \\
\hline Transportation & 2.76 & 2.80 & 2.77 \\
\hline Communications & 4.48 & 4.47 & 4.47 \\
\hline Electricity & 2.17 & 2.12 & 2.01 \\
\hline Gas & -1.87 & -1.81 & -4.40 \\
\hline Wholesale trade & 4.33 & 2.49 & 5.35 \\
\hline Retail and eating & 2.65 & 2.90 & 2.48 \\
\hline Finance & 7.72 & 7.60 & 7.74 \\
\hline Insurance & 2.29 & 4.15 & 0.50 \\
\hline Real estate (rental) & 2.74 & 2.83 & 2.71 \\
\hline Computer services & 13.52 & 15.94 & 12.00 \\
\hline Business svc., excl. computer & 5.16 & 3.24 & 6.30 \\
\hline Health, private & 3.18 & 4.67 & 2.47 \\
\hline Legal & 1.86 & 1.55 & 2.61 \\
\hline Education, private & 2.45 & 2.80 & 2.23 \\
\hline Professional and social svcs. & 4.36 & 4.36 & 4.42 \\
\hline Other services & 3.29 & 3.57 & 3.13 \\
\hline Government enterprises & 2.46 & 3.03 & 2.13 \\
\hline Household & 3.69 & 0.00 & 3.69 \\
\hline Government, excl. education & 1.38 & 0.00 & 1.38 \\
\hline Government education & 2.13 & 0.00 & 2.13 \\
\hline Average & 3.58 & 3.41 & 4.09 \\
\hline
\end{tabular}

Note: All figures are average annual growth rates. 


\begin{tabular}{|c|c|c|c|c|}
\hline Industry name & $1977-2000$ & $1977-90$ & $1990-95$ & $1995-2000$ \\
\hline Agriculture & 2.40 & 2.25 & 1.87 & 3.33 \\
\hline Non-energy mining & 1.53 & 1.37 & 1.67 & 1.80 \\
\hline Coal mining & 1.89 & 3.04 & -0.01 & 0.80 \\
\hline Oil and gas mining & -0.32 & -0.56 & -1.13 & 1.10 \\
\hline Construction & 1.65 & 1.22 & -0.07 & 4.48 \\
\hline Lumber, wood, furniture & 2.00 & 1.67 & 1.59 & 3.25 \\
\hline Stone, clay, glass & 1.65 & 0.31 & 1.19 & 5.60 \\
\hline Primary metal & 0.22 & -1.74 & 2.49 & 3.04 \\
\hline Fabricated metal & 1.98 & 0.13 & 3.18 & 5.58 \\
\hline Machinery, excl. computers & 1.40 & -0.62 & 4.16 & 3.88 \\
\hline Computers and office equipment & 23.70 & 21.65 & 21.19 & 31.50 \\
\hline Other electrical machinery & 2.28 & 1.08 & 4.10 & 3.56 \\
\hline Communications equipment & 8.73 & 6.07 & 9.84 & 14.52 \\
\hline Electronic components & 18.15 & 12.32 & 22.80 & 28.65 \\
\hline Motor vehicles & 2.60 & -0.08 & 6.08 & 6.07 \\
\hline Other transportation equipment & 2.32 & 3.89 & -5.43 & 5.99 \\
\hline Instruments and miscellaneous mfg. & 3.25 & 3.47 & 1.76 & 4.18 \\
\hline Food and tobacco & 1.60 & 1.47 & 2.01 & 1.52 \\
\hline Textiles, apparel, leather & 0.33 & 0.01 & 2.57 & -1.07 \\
\hline Paper & 1.64 & 1.98 & 1.62 & 0.79 \\
\hline Printing and publishing & 2.06 & 2.90 & -0.05 & 1.97 \\
\hline Chemicals & 1.45 & 1.20 & 1.36 & 2.20 \\
\hline Petroleum refining & 0.47 & 0.05 & 0.53 & 1.50 \\
\hline Rubber and plastic & 3.61 & 3.03 & 5.28 & 3.45 \\
\hline Transportation & 2.76 & 2.45 & 3.55 & 2.81 \\
\hline Communications & 4.48 & 3.79 & 4.34 & 6.41 \\
\hline Electricity & 2.17 & 2.27 & 1.19 & 2.87 \\
\hline Gas & -1.87 & -2.20 & -2.24 & -0.65 \\
\hline Wholesale trade & 4.33 & 4.47 & 4.14 & 4.16 \\
\hline Retail and eating & 2.65 & 2.30 & 2.03 & 4.17 \\
\hline Finance & 7.72 & 7.63 & 5.65 & 10.00 \\
\hline Insurance & 2.29 & 3.30 & 0.48 & 1.48 \\
\hline Real estate (rental) & 2.74 & 3.01 & 2.38 & 2.40 \\
\hline Computer services & 13.52 & 14.38 & 11.45 & 13.38 \\
\hline Business svc., excl. computer & 5.16 & 4.66 & 4.05 & 7.58 \\
\hline Health, private & 3.18 & 3.75 & 2.22 & 2.66 \\
\hline Legal & 1.86 & 2.78 & -0.61 & 1.95 \\
\hline Education, private & 2.45 & 2.72 & 1.32 & 2.87 \\
\hline Professional and social svcs. & 4.36 & 5.02 & 2.34 & 4.67 \\
\hline Other services & 3.29 & 2.83 & 3.36 & 4.42 \\
\hline Government enterprises & 2.46 & 2.40 & 1.63 & 3.44 \\
\hline Household & 3.69 & 3.59 & 2.76 & 4.85 \\
\hline Government, excl. education & 1.38 & 2.04 & 0.19 & 0.86 \\
\hline Government education & 2.13 & 2.04 & 2.36 & 2.15 \\
\hline Average & 3.58 & 3.17 & 3.21 & 5.01 \\
\hline
\end{tabular}

Note: All figures are average annual growth rates. 
1977-90, 1990-95, and 1995-2000. Output growth is most rapid for the ITproducing industries during the 1990s, but the growth of Finance outpaces that of Communications Equipment before 1990. The second echelon of four industries in at least one of the three subperiods includes six industries, indicating the range of industries with relatively rapid growth.

Table 11.6 gives growth rates of intermediate input for the three subperiods. Again, growth is most rapid for the IT-producing industries during the 1990s, but Finance outstrips Communications Equipment before 1990. The second echelon of four industries in at least one of the three subperiods includes eleven industries, indicating the widespread importance of intermediate inputs.

Finally, table 11.7 shows growth rates of value added for the three subperiods. The growth of value added in the IT-producing sectors is strong for all three subperiods, but Petroleum Refining leads Communications Equipment and Computer Services during 1990-95 and Finance leads Communications Equipment during 1995-2000. The second echelon of four industries in at least one subperiod includes ten industries, showing the range of industries with relatively rapid growth in value added.

Our overall conclusion from these results is that the IT-producing sectors stand out in terms of rapid growth of output, intermediate input, and value added for the period 1977-2000 as a whole and for the three subperiods. Finance surpasses Communications Equipment in growth of value added for the period as a whole and a number of industries have more rapid growth of intermediate input and/or value added during one or more subperiods. Nonetheless, the picture that emerges from these data is one of rapid growth of the IT-producing industries for the period as a whole and accelerating growth during the period 1995-2000.

\subsection{Measuring Capital Input}

This section outlines our methodology for measuring the flow of capital services in each industry. The key objective is to account for substitution among assets with different marginal products. The methodology was originated by Jorgenson and Griliches (1995), who constructed price and quantity indexes for capital input, based on Jorgenson's (1996) model of the corporate cost of capital. These indexes were extended to the industry level for all three legal forms of organization - corporate, noncorporate, and household - by Jorgenson, Gollop, and Fraumeni (1987, chap. 4) and updated and revised by Jorgenson (1995b).

We incorporate recent methodological changes developed by Jorgenson and Stiroh (2000). These include the use of asset-specific revaluation terms in the service price equation. In addition, capital service flows from new investments are assumed to become available in the middle of the year, rather than at the end of the year, as in our earlier work. 


\begin{tabular}{|c|c|c|c|c|}
\hline Industry name & $1977-2000$ & $1977-90$ & $1990-95$ & 1995-2000 \\
\hline Agriculture & 0.73 & 0.10 & 1.00 & 2.11 \\
\hline Non-energy mining & 1.05 & 0.87 & 0.37 & 2.19 \\
\hline Coal mining & 1.25 & 4.85 & -4.01 & -2.82 \\
\hline Oil and gas mining & -0.12 & 1.43 & -4.19 & -0.08 \\
\hline Construction & 2.66 & 2.14 & 0.99 & 5.66 \\
\hline Lumber, wood, furniture & 1.91 & 0.89 & 4.02 & 2.46 \\
\hline Stone, clay, glass & 1.75 & 0.14 & 1.55 & 6.12 \\
\hline Primary metal & -0.38 & -1.91 & 2.81 & 0.40 \\
\hline Fabricated metal & 2.07 & 0.59 & 2.72 & 5.25 \\
\hline Machinery, excl. computers & 2.43 & 0.54 & 4.87 & 4.91 \\
\hline Computers and office equipment & 14.99 & 13.48 & 14.73 & 19.21 \\
\hline Other electrical machinery & 2.92 & 1.22 & 5.12 & 5.17 \\
\hline Communications equipment & 10.01 & 4.53 & 14.24 & 20.04 \\
\hline Electronic components & 11.02 & 6.81 & 17.19 & 15.81 \\
\hline Motor vehicles & 3.11 & 0.37 & 6.99 & 6.32 \\
\hline Other transportation equipment & 3.28 & 4.41 & -5.03 & 8.63 \\
\hline Instruments and miscellaneous $\mathrm{mfg}$. & 4.51 & 3.56 & 4.45 & 7.06 \\
\hline Food and tobacco & 1.28 & 1.13 & 1.50 & 1.45 \\
\hline Textiles, apparel, leather & -0.33 & -0.54 & 2.66 & -2.80 \\
\hline Paper & 1.53 & 2.31 & 2.86 & -1.82 \\
\hline Printing and publishing & 2.42 & 3.74 & 0.40 & 1.01 \\
\hline Chemicals & 1.47 & 1.41 & 1.64 & 1.43 \\
\hline Petroleum refining & 1.23 & 0.26 & -1.52 & 6.51 \\
\hline Rubber and plastic & 2.37 & 1.67 & 4.90 & 1.67 \\
\hline Transportation & 2.80 & 2.82 & 2.87 & 2.66 \\
\hline Communications & 4.47 & 2.88 & 4.76 & 8.33 \\
\hline Electricity & 2.12 & 2.85 & 0.83 & 1.51 \\
\hline Gas & -1.81 & -2.21 & -0.61 & -1.99 \\
\hline Wholesale trade & 2.49 & 1.32 & 4.01 & 4.02 \\
\hline Retail and eating & 2.90 & 2.92 & 2.27 & 3.47 \\
\hline Finance & 7.60 & 6.79 & 6.01 & 11.31 \\
\hline Insurance & 4.15 & 6.02 & 0.85 & 2.58 \\
\hline Real estate (rental) & 2.83 & 3.03 & 1.62 & 3.49 \\
\hline Computer services & 15.94 & 15.34 & 14.35 & 19.08 \\
\hline Business svc., excl. computer & 3.24 & 0.94 & 3.94 & 8.49 \\
\hline Health, private & 4.67 & 4.96 & 4.84 & 3.77 \\
\hline Legal & 1.55 & 0.48 & 1.05 & 4.84 \\
\hline Education, private & 2.80 & 2.64 & 2.18 & 3.84 \\
\hline Professional and social svcs. & 4.36 & 3.95 & 3.24 & 6.56 \\
\hline Other services & 3.57 & 2.45 & 4.77 & 5.27 \\
\hline Government enterprises & 3.03 & 2.90 & 3.05 & 3.35 \\
\hline Household & 0.00 & 0.00 & 0.00 & 0.00 \\
\hline Government, excl. education & 0.00 & 0.00 & 0.00 & 0.00 \\
\hline Government education & 0.00 & 0.00 & 0.00 & 0.00 \\
\hline Average & 3.41 & 2.78 & 3.42 & 5.04 \\
\hline
\end{tabular}

Note: All figures are average annual growth rates. 
Table 11.7

Growth of industry value added, by subperiod

\begin{tabular}{|c|c|c|c|c|}
\hline Industry name & $1977-2000$ & $1977-90$ & $1990-95$ & 1995-2000 \\
\hline Agriculture & 4.74 & 5.44 & 3.03 & 4.64 \\
\hline Non-energy mining & 1.89 & 1.69 & 2.91 & 1.40 \\
\hline Coal mining & 2.88 & 2.77 & 2.89 & 3.13 \\
\hline Oil and gas mining & 0.12 & -1.34 & 1.77 & 2.28 \\
\hline Construction & 0.40 & 0.13 & -1.45 & 2.92 \\
\hline Lumber, wood, furniture & 2.21 & 2.98 & -2.02 & 4.43 \\
\hline Stone, clay, glass & 1.55 & 0.48 & 0.80 & 5.05 \\
\hline Primary metal & 1.61 & -1.29 & 1.71 & 9.06 \\
\hline Fabricated metal & 1.87 & -0.43 & 3.77 & 5.97 \\
\hline Machinery, excl. computers & 0.33 & -1.78 & 3.40 & 2.74 \\
\hline Computers and office equipment & 42.01 & 35.12 & 36.40 & 65.54 \\
\hline Other electrical machinery & 1.40 & 0.91 & 2.71 & 1.36 \\
\hline Communications equipment & 7.36 & 7.33 & 5.94 & 8.85 \\
\hline Electronic components & 25.44 & 17.43 & 28.74 & 42.94 \\
\hline Motor vehicles & 0.94 & -1.39 & 2.84 & 5.07 \\
\hline Other transportation equipment & 1.38 & 3.37 & -5.84 & 3.44 \\
\hline Instruments and miscellaneous $\mathrm{mfg}$. & 2.23 & 3.40 & -0.34 & 1.76 \\
\hline Food and tobacco & 2.51 & 2.59 & 3.13 & 1.66 \\
\hline Textiles, apparel, leather & 1.49 & 0.93 & 2.42 & 2.04 \\
\hline Paper & 1.80 & 1.41 & -0.45 & 5.03 \\
\hline Printing and publishing & 1.73 & 2.20 & -0.42 & 2.65 \\
\hline Chemicals & 1.44 & 0.91 & 1.00 & 3.24 \\
\hline Petroleum refining & 1.26 & 5.86 & 14.14 & -23.57 \\
\hline Rubber and plastic & 5.23 & 4.87 & 5.76 & 5.65 \\
\hline Transportation & 2.77 & 2.13 & 4.20 & 2.98 \\
\hline Communications & 4.47 & 4.50 & 4.02 & 4.83 \\
\hline Electricity & 2.01 & 1.65 & 1.38 & 3.56 \\
\hline Gas & -4.40 & -6.09 & -6.61 & 2.18 \\
\hline Wholesale trade & 5.35 & 6.23 & 4.20 & 4.24 \\
\hline Retail and eating & 2.48 & 1.87 & 1.86 & 4.68 \\
\hline Finance & 7.74 & 8.11 & 5.41 & 9.10 \\
\hline Insurance & 0.50 & 0.83 & 0.03 & 0.10 \\
\hline Real estate (rental) & 2.71 & 3.00 & 2.61 & 2.08 \\
\hline Computer services & 12.00 & 13.83 & 9.66 & 9.60 \\
\hline Business svc., excl. computer & 6.30 & 6.78 & 4.08 & 7.27 \\
\hline Health, private & 2.47 & 3.19 & 0.97 & 2.10 \\
\hline Legal & 2.61 & 4.78 & -1.23 & 0.79 \\
\hline Education, private & 2.23 & 2.83 & 0.72 & 2.17 \\
\hline Professional and social svcs. & 4.42 & 5.64 & 1.93 & 3.75 \\
\hline Other services & 3.13 & 3.24 & 2.23 & 3.73 \\
\hline Government enterprises & 2.13 & 2.11 & 0.84 & 3.49 \\
\hline Household & 3.69 & 3.59 & 2.76 & 4.85 \\
\hline Government, excl. education & 1.38 & 2.04 & 0.19 & 0.86 \\
\hline Government education & 2.13 & 2.04 & 2.36 & 2.15 \\
\hline Average & 4.09 & 3.77 & 3.51 & 5.50 \\
\hline
\end{tabular}

Note: All figures are average annual growth rates. 


\subsubsection{Notation}

We begin with notation for measures of investment, capital stocks, and capital services for individual assets and industry aggregates. The subscript $k$ refers to the specific asset, while $j$ refers to the industry; time subscripts are suppressed wherever possible. For individual assets we have

$I_{k, j} \quad$ quantity of investment

$P_{I, k, j} \quad$ price of investment

$\delta_{k} \quad$ geometric depreciation rate

$Z_{k, j} \quad$ quantity of capital stock

$P_{I, k, j} \quad$ price of capital stock

$K_{k, j} \quad$ quantity of capital services

$P_{K, k, j} \quad$ price of capital services

For industry aggregates:

$I_{j} \quad$ quantity index of industry investment

$P_{I, j} \quad$ price index of industry investment

$Z_{j} \quad$ quantity index of industry capital stock

$P_{Z, j} \quad$ price index of industry capital stock

$K_{j} \quad$ quantity index of industry capital services

$P_{K, j} \quad$ price of industry capital services

$Q_{K, j} \quad$ index of industry capital quality

\subsubsection{Methodology for Estimating Capital Service Flows}

For each industry, we begin with data on the quantity of investment in each individual asset $I_{k, j}$. We assume that the price index for each asset transforms nominal investment in different time periods into identical "efficiency units" over time, so that investments of different vintages are perfect substitutes in production. Improvements in the performance of capital input - for example, a faster processor in a computer-are incorporated into the price index that transforms the current vintage of investment into an equivalent number of efficiency units of earlier vintages. As a concrete example, the constant-quality price index for computer equipment transforms more recent investments in faster, more powerful, computers into additional units of constant efficiency base-year capital.

We transform data on the quantities of investment into estimates of capital stocks for all assets, industries, and years through the familiar perpetual inventory method. This is consistent with the assumption of perfect substitutability across vintages and defines the capital stock for each industry and asset as

$$
Z_{k, j, t}=Z_{k, j, t-1}\left(1-\delta_{k}\right)+I_{j, k, t}=\sum_{\tau=0}^{\infty}\left(1-\delta_{k}\right)^{\tau} I_{j, k, t-\tau},
$$


where the efficiency of an asset is assumed to decline geometrically with age at the rate $\delta_{k}$.

Equation (12) has the interpretation that capital stock is a weighted sum of past investments, where the weights are derived from the relative efficiencies of capital of different ages, captured by the geometric rate of decline. Note that the rates of decline in efficiency $\delta_{k}$ are indexed by asset only. Finally, because all capital is measured in base-year efficiency units, the appropriate price for valuing the capital stock is the investment price deflator $P_{I, k}$.

The installed stock of capital $Z_{k, j}$ represents the accumulation of past investments, but we are primarily interested in $K_{k, j}$, the flow of capital services from that stock over a given period. This distinction is not critical for individual assets, but it becomes essential when we aggregate heterogeneous assets to form an industry or economywide aggregate. For each asset we assume that new investment becomes available for production at the midpoint of the year so the flow of capital services for each industry and each asset is proportional to the arithmetic average of the current and lagged capital stock:

$$
K_{k, j, t}=q_{k, j}\left(0.5 \cdot Z_{j, k, t}+0.5 \cdot Z_{j, k, t-1}\right),
$$

where $q_{k, j}$ denotes the proportionality constant, normalized to one.

We estimate a price of capital services that corresponds to the quantity of capital input via the cost-of-capital formula. In equilibrium, with no uncertainty, investors are indifferent between two alternatives: earning a nominal rate of return $i_{t}$ on a different investment or buying a unit of capital, collecting a rental fee, and then selling the depreciated asset in the next period. For investors purchasing the asset, the cost of capital equals the marginal product of the asset. This implies the familiar cost of capital, or user cost, for each asset in each industry:

$$
P_{K, k, j, t}=\left(i_{j, t}-\pi_{k, j, t}\right) P_{k, j, t-1}+\delta_{k} P_{I, k, j, t},
$$

where the asset-specific capital gains term is $\pi_{k, j, t}=\left(P_{I, k, j, t}-P_{I, k, j, t-1}\right) / P_{I, k, j, t-1}$ and $i_{j, t}$ is the nominal rate of return in industry $j$.

The cost of capital accounts for the nominal rate of return, asset-specific depreciation, and an asset-specific revaluation term. An asset with a higher depreciation rate has a higher marginal product and must receive a higher capital service price as compensation. Similarly, if an investor expects a capital loss $\left(\pi_{k, j, t}<0\right)$, then a higher service price is required. Jorgenson and Stiroh (2000) and Oliner and Sichel (2000) discuss the importance of incorporating asset-specific revaluation terms for information technology assets experiencing rapid downward revaluations.

Tax considerations are also a key component of capital service prices, as discussed by Hall and Jorgenson (1996) and developed in detail by Jorgenson and Yun (2001). We follow Jorgenson and Stiroh (2000) and Jorgenson 
and Yun in accounting for investment tax credits, capital consumption allowances, the statutory tax rate, property taxes, debt/equity financing, and personal taxes, by estimating an asset-specific, after-tax real rate of return for each asset in each industry, $r_{k, j, t}$, that enters the cost-of-capital formula:

$$
P_{K, k, j, t}=\frac{1-I T C_{k, t}-\tau_{t} z_{k, t}}{1-\tau_{t}}\left(r_{k, j, t} P_{I, k, j, t-1}+\delta_{k} P_{I, k, j, t}\right)+\tau_{p} P_{I, k, j, t-1},
$$

where $I T C_{k, t}$ is the investment tax credit, $\tau_{t}$ is the statutory tax rate, $z_{k, t}$ is the present value of capital consumption allowances for tax purposes, and $\tau_{p}$ is a property tax rate, all for asset $k$ at time $t$. For the corporate sector, the rate of return, $r_{k, j, t}$, is calculated as a weighted average of real, after-tax returns to debt and equity. We then assume the after-tax rate of return to all assets in each industry is the same and exhaust the value of payments to capital across all assets in the corporate sector of each industry. Jorgenson and Yun provide details about the procedure and differences across the corporate, noncorporate, and household sectors.

Equations (12) through (15) describe our estimation procedure for the capital service flow and capital service price, $K_{k, j, t}$ and $P_{K, k, j, t}$, respectively, for each asset, industry, and time period. We combine capital services for all assets within an industry by means of a Tornqvist quantity index as

$$
\Delta \ln K_{j}=\sum_{k} \bar{v}_{k, j} \Delta \ln K_{k, j},
$$

where the $\bar{v}_{k, j}$ weights are the two-period average shares of each type of capital income in total capital income and the corresponding price index of capital inputs $P_{K, j}$ is defined implicitly to make the value identity hold:

$$
P_{K, j} K_{j}=\sum_{k} P_{K, k, j} K_{k, j} \cdot
$$

Similarly, the quantity of capital stock is defined by

$$
\Delta \ln Z_{j}=\sum_{k} \bar{w}_{k, j} \Delta \ln K_{k, j},
$$

where the $\bar{w}_{k, j}$ weights are the two-period average nominal shares of each type of capital stock in total capital stock and the corresponding price index for capital stock $P_{Z, j, t}$ is defined implicitly from the identity

$$
P_{Z, j, t} Z_{j, t}=\sum_{k} P_{I, k, j, t} K_{k, j, t} .
$$

Finally, we define capital quality $Q_{K, j}$ for industry $j$ as the ratio of capital input to capital stock:

$$
Q_{K, j}=\frac{K_{j}}{Z_{j}}
$$


Note that quantity indexes of capital inputs and capital stocks aggregate the same asset quantities $K_{k, j}$ by means of a Tornqvist index; the difference is the use of service prices versus asset prices as weights. This implies that growth in capital quality reflects substitution toward assets with relatively high service prices and high marginal products. For example, large depreciation rates and rapid downward revaluations for computers imply that these assets have high marginal products, so their weight in an index of capital services exceeds their weight in an index of capital assets. Substitution toward computers as computer prices fall implies that capital input grows faster than capital stock; this is captured by our index of capital quality. Second, our measure of industry capital stock is implicitly a two-period average, as it aggregates two-period averages of capital stocks using current asset prices.

Finally, we break down IT capital and non-IT capital. The capital services of IT assets $K_{\mathrm{IT}, j}$ include the service flows from computer hardware, software, and communications equipment, while the non-IT capital service flow $K_{\mathrm{NON}, j}$ includes the services from all other equipment, structures, inventories, and land. We create subindexes of capital services as

$$
\begin{aligned}
\Delta \ln K_{\mathrm{IT}, j} & =\sum_{k \in \mathrm{IT}} \bar{v}_{\mathrm{IT}, k, j} \Delta \ln K_{\mathrm{IT}, j} \\
\Delta \ln K_{\mathrm{NON}, j} & =\sum_{k \notin \mathrm{IT}} \bar{v}_{\mathrm{NON}, k, j} \Delta \ln K_{\mathrm{NON}, j},
\end{aligned}
$$

where the shares are those of IT capital and non-IT capital, respectively.

\subsubsection{Data}

Our primary data source for capital input is the Tangible Wealth Survey produced by the BEA and described in Herman (2000a,b). These data include detailed investment by industry and asset class and contain historical cost investment and chain-type quantity indexes for sixty-one types of nonresidential assets from 1901 to 2000, forty-eight types of residential assets from 1901 to 2000 , and thirteen different types of consumers' durables from 1925 to 2000 . Nonresidential investment is available for sixty-two industries, which we collapse into forty-four industries, including private households and governments.

Several data adjustments are worth mentioning. First, for each of the forty-one private industries, we reclassify the BEA data on sixty-one nonresidential assets into fifty-two nonresidential assets. The residential assets and thirteen consumers' durable assets are allocated to the real estate and household industries. Second, we combine investment in residential equipment with other equipment in the nonresidential category. Third, we control the total value of investment in major categories-equipment and software, nonresidential structures, residential structures, and total consumer durables - to match the totals in the NIPA. These adjustments lead 
to a complete time series of fifty-seven assets in both current and chained 1996 dollars for each of the forty-four industries. The investment and capital data are then allocated across three ownership categories - corporate, noncorporate, and households - based on shares provided by the BEA. There is no ownership breakdown for household and government industry data. Finally, we use prices for each asset from the NIPA.

Geometric depreciation rates for the perpetual inventory calculations are based on Fraumeni (1997) with the exceptions of computers and automobiles. As described in Jorgenson and Stiroh (2000), the BEA reports nongeometric profiles for these assets, and we estimate best geometric approximation of 0.315 for computers and software and 0.272 for automobiles.

We have collected data on inventories and land to complete our capital estimates. Inventory data come primarily from the NIPA in the form of farm and nonfarm inventories, allocated across industries. These are measured in current dollars with a corresponding price index. Inventories are assumed to have a depreciation rate of zero and do not qualify for an investment tax credit or capital consumption allowances for tax purposes, so the capital rental price formula is a simplified version of equation (15).

Data on land are more problematic. Through 1995 the Federal Reserve Board $(1995,1997)$ published detailed data on land values and quantities in its "Balance Sheets for the U.S. Economy," but the underlying data became unreliable and are no longer published. We use the limited land data available in the "Flow of Funds Accounts of the United States" and historical data described in Jorgenson (1995b) to estimate a price and a quantity of private land. As a practical matter, this quantity series varies very little, so its major impact is to slow the growth of capital stock and capital input. Like inventories, the depreciation, investment tax credit, and capital consumption allowance for land are zero.

Finally, we have collected data on industry-level value added from the "Gross Product Originating" database maintained by the BEA and described in Lum and Moyer (2000) and from the BLS, as described above. The BEA data include the value of output, value added, and intermediate inputs for sixty-two industries from 1947 to 2000. We have aggregated these industries to match our forty-four industries. For the estimation of capital service prices, we begin with value added in the corporate sector and subtract corporate labor income to estimate the amount of income available to corporate capital. Similarly, we subtract noncorporate labor income from value added, as described in the following section, to obtain the value of noncorporate capital income.

\subsubsection{Issues}

Although the methodology described above conforms to the international standards recommended by Blades (2001) and Schreyer (2001) of the OECD, there are important issues related to the availability of data and 
the plausibility of certain assumptions that arise in the implementation of this methodology. This subsection outlines these issues and describes our solutions.

\section{Negative Service Prices}

The intuition behind our estimation of capital service prices is that the value of capital service flows must exhaust capital income. One problem is that there is very little income available to capital in some years and this leads to negative estimates of service prices. For example, if asset inflation rates are high and depreciation rates are low, relative to the interest rate, negative service prices may result. Economically, this is possible and suggests that capital gains are higher than expected, so that a small service price is possible in equilibrium. Berndt and Fuss (1986) and Diewert (chap. 12 in this volume) discuss this issue in more detail.

Empirically, however, negative service prices make aggregation difficult, so we have made adjustments for several assets. Certain assets showed negative service prices, notably inventories, land, and structures in the 1970s, when inflation was high. Our first adjustment of the data was to use a smoothed inflation rate from the surrounding years rather than the current inflation in the cost of capital calculation. Land showed large capital gains throughout and has no depreciation, so that we used the economywide rate of asset inflation for all years. As a last resort, we were forced to impute additional income, which added to both capital income and the value of output, but this is a relatively small issue empirically.

\section{Deflators}

The methodology described above allows for deflators for each asset to differ across industries. In practice, however, the industry-specific deflators for certain assets were quite erratic across industries and time. The Tangible Wealth Survey reports investment in millions of dollars with no decimal points, so any asset with a very small value and quantity in a given year has a deflator that is not estimated precisely. We simply aggregated each asset across all industries and used the economywide average deflator to remove the noise.

A second concern is our reliance on the deflators incorporated in the Tangible Wealth Survey and the NIPAs. For most assets this is not a problem, but Jorgenson and Stiroh (2000) argue that the official deflators do not fully account for quality change in software and communications equipment. For these assets only a small share of investment is associated with constant-quality deflators, leading to an overstatement of price increases and an understatement of quantity increases. The software and communications equipment deflators, for example, rose at annual rates of 1.1 and 1.8 percent per year for 1959 to 1999 , compared to a decline of 18.8 for computer hardware. We do not address this issue here but simply observe that these data may understate the growth of IT capital input in all industries. 


\section{Depreciation Rates}

There has been considerable debate about the appropriate depreciation rates for assets with constant-quality deflators. As pointed out by Oliner (1993, 1994) and, more recently, by Whelan (2002), if the quantity of investment is constructed with a constant-quality deflator, the depreciation rate should be obtained from constant-quality price data by age of asset. This corresponds to "partial depreciation" in Oliner's terminology. Otherwise, the cost-of-capital formula in equation (14) would count depreciation twice: once through the asset-specific inflation rate and again through the asset-specific depreciation rate. This is a major issue for computer hardware. The BEA depreciation rates currently incorporate Oliner's (1993, 1994) estimates for all computer components except personal computers. According to Herman (2000a), the personal computer depreciation profile is based on a study by Lane (1999). Our best geometric approximation to the BEA depreciation rates, however, does not use this new estimate; rather, we employ the earlier BEA profile based on the work of Oliner $(1993,1994)$.

\section{Capital Use Matrix}

The detailed investment data by industry and assets are based on a relatively old, and perhaps outdated, view of the composition of industry investment. Investment for a given asset is allocated across industries, based on a capital flow table produced by the BEA (see Bonds and Aylor 1998). This capital-use matrix is estimated for benchmark interindustry transaction tables at five-year intervals. The latest capital-use matrix incorporated here is from 1992, and more recent data would obviously be very valuable.

\section{Capital for IT-Producing Industries}

The Tangible Wealth data produced by the BEA report capital data for roughly two-digit SIC industries but provide no breakdown for the ITproducing industries in which we are particularly interested. We have capital data for industries like Commercial and Industrial Machinery (SIC 35) but not for the detailed components like Computers and Office Equipment (SIC 357). This limitation forced us to use a variety of data sources to estimate the capital service flow for the IT-producing industries.

The detailed BLS industry value-added data allow us to split the broad industry value added into component industries. Similarly, we combine detailed data from the Current Population Survey (CPS) and decennial Census (discussed below) with BLS and NIPA employment data to estimate total labor compensation for component industries. The value of capital income for each component industry is obtained by dividing broad industry capital income using the implied capital shares from the component industry value added and labor compensation. Finally, we assumed that all components of the broad industry faced the same capital service and capital stock prices, which were estimated as described above based on 
two-digit SIC data available in the Tangible Wealth survey. The quantity of capital services was then calculated as the estimated capital income for each component industry divided by the common service price. Similarly, capital quality was assumed constant across detailed industries within the broader two-digit industries, which allowed estimates of capital stock to be retrieved.

While this approach is not ideal, it makes the best use of the limited data available. We have estimates of the value of capital income, but if the ITproducing industries are investing in a different mix of assets-for example, more heavily in IT-related assets - then this approach will misstate the growth of capital input and the TFP residual. While it seems likely that this will understate capital input and overstate TFP growth, we cannot gauge the magnitude of the bias without better data on investment patterns for these industries.

\section{Corporate and Noncorporate Capital Services}

The final issue is the allocation of capital between the corporate and noncorporate sectors; this is important because of the differential taxation of corporate income (Jorgenson and Yun 2001). As discussed above, BEA data permit us to split the capital stock, but we have no direct information on the capital income to allocate to each sector. In Jorgenson, Gollop, and Fraumeni (1987) and Jorgenson and Stiroh (2000), this allocation assumed that the nominal rate of return in the noncorporate sector matched the estimated nominal rate of return in the corporate sector after corporate taxes. Noncorporate labor income was then estimated as residual. For many of the small industries, however, this led to unstable estimates of average wages and labor quality.

We now allocate income to the noncorporate sector by assuming that labor compensation per hour is equal for corporate employees and selfemployed and unpaid family workers for each type of labor in each sector. We then estimate capital income in the noncorporate sector as a residual (observed noncorporate value added less estimated noncorporate labor income). While this leads to fluctuations in the rate of return for some sectors, the relatively small size of the noncorporate sector in most industries mitigates this effect. In industries with large noncorporate sectors, like Agriculture and Real Estate, our new estimates are quite different from our earlier ones.

\subsubsection{Results}

Table 11.8 presents growth rates of capital input, IT capital input, and non-IT capital input for the period 1977-2000. The growth of capital input is greatest for Electronic Components and Computer Services, two IT-producing industries, and for Finance and Insurance, two IT-using industries. The second echelon of four industries includes Other Business 


\begin{tabular}{|c|c|c|c|}
\hline Industry name & Total & IT & Non-IT \\
\hline Agriculture & 0.48 & 22.19 & 0.37 \\
\hline Non-energy mining & 1.35 & 24.54 & 0.97 \\
\hline Coal mining & 0.63 & 27.53 & 0.33 \\
\hline Oil and gas mining & 2.47 & 20.16 & 2.16 \\
\hline Construction & 2.27 & 24.28 & 1.58 \\
\hline Lumber, wood, furniture & 1.71 & 19.44 & 1.14 \\
\hline Stone, clay, glass & 1.58 & 13.70 & 0.63 \\
\hline Primary metal & -0.10 & 14.04 & -0.54 \\
\hline Fabricated metal & 2.04 & 20.32 & 1.20 \\
\hline Machinery, excl. computers & 5.37 & 16.72 & 2.86 \\
\hline Computers and office equipment & 4.58 & 15.93 & 2.07 \\
\hline Other electrical machinery & -0.57 & 8.91 & -2.38 \\
\hline Communications equipment & 7.08 & 16.56 & 5.27 \\
\hline Electronic components & 14.90 & 24.38 & 13.09 \\
\hline Motor vehicles & 2.05 & 18.65 & 1.41 \\
\hline Other transportation equipment & 5.66 & 20.88 & 3.11 \\
\hline Instruments and miscellaneous $\mathrm{mfg}$. & 5.40 & 22.52 & 2.75 \\
\hline Food and tobacco & 2.22 & 18.43 & 1.68 \\
\hline Textiles, apparel, leather & 1.22 & 17.06 & 0.42 \\
\hline Paper & 2.97 & 16.61 & 2.47 \\
\hline Printing and publishing & 5.08 & 22.55 & 2.17 \\
\hline Chemicals & 2.83 & 21.79 & 2.08 \\
\hline Petroleum refining & 1.16 & 10.84 & 0.95 \\
\hline Rubber and plastic & 3.97 & 18.79 & 3.16 \\
\hline Transportation & 2.33 & 17.32 & 1.18 \\
\hline Communications & 6.23 & 7.03 & 5.27 \\
\hline Electricity & 2.18 & 18.56 & 1.57 \\
\hline Gas & 2.53 & 25.86 & 1.24 \\
\hline Wholesale trade & 8.98 & 24.13 & 4.87 \\
\hline Retail and eating & 4.74 & 28.79 & 3.37 \\
\hline Finance & 10.61 & 21.97 & 6.86 \\
\hline Insurance & 10.25 & 20.80 & 7.36 \\
\hline Real estate (rental) & 2.47 & 15.29 & 2.11 \\
\hline Computer services & 14.23 & 28.93 & 8.17 \\
\hline Business svc., excl. computer & 9.26 & 23.97 & 3.20 \\
\hline Health, private & 5.86 & 27.45 & 4.71 \\
\hline Legal & 6.12 & 21.61 & 2.88 \\
\hline Education, private & 4.66 & 14.12 & 3.39 \\
\hline Professional and social svcs. & 6.94 & 24.73 & 4.36 \\
\hline Other services & 4.37 & 16.35 & 3.61 \\
\hline Government enterprises & 3.09 & 16.18 & 1.65 \\
\hline Household & 3.69 & 13.99 & 3.13 \\
\hline Government, excl. education & 2.83 & 13.41 & 1.64 \\
\hline Government education & 4.13 & 14.70 & 2.93 \\
\hline Average & 4.36 & 19.36 & 2.78 \\
\hline
\end{tabular}

Note: All figures are average annual growth rates. IT capital includes computer hardware, computer software, and telecommunications equipment. 
Services, Wholesale Trade, Communications Equipment, and Professional and Social Services. While growth of capital input for Computers is substantial, this industry falls below the second echelon.

Growth of IT capital input dominates that of non-IT capital input for all industries. The growth rate of IT capital input is highest for Computer Services, Retail and Eating, Coal Mining, and Health Services, while the second echelon of four industries includes Gas Utilities, Professional and Social Services, Non-Energy Mining, and Electronic Components. Electronic Components and Computer Services, two IT-producing industries, and Finance and Insurance, two IT-using industries, are also the leaders in the growth of non-IT capital input. The second echelon includes Communications Services and Communications Equipment as well as Wholesale Trade and Health Services.

Table 11.9 shows growth rates of capital input for the three subperiods. Electronic Components and Computer Services, along with Finance and Insurance, lead before 1990, with Other Services replacing Finance during 1990-95. Computers, Communications Equipment, Computer Services, and Other Business Services lead the surge in investment after 1995. The second echelon of four industries in at least one subperiod includes nine additional industries, indicating the breadth of the importance of investment.

Table 11.10 gives growth rates of IT capital input for the three subperiods. Before 1990 the leading sectors are Retail and Eating, Gas Utilities, Computer Services, and Health Services. During the period 1990-95 new industries lead in growth of IT capital input-Coal Mining, Construction, and Non-energy Mining, as well as Electronic Components. The surge in growth of capital input after 1995 is led by Computers, Computer Services, Other Business Services, and Stone, Clay, and Glass. The second echelon of four industries leading in at least one subperiod includes nine additional industries.

Finally, table 11.11 presents growth rates of non-IT Capital Input for the three subperiods. Before 1990 Electronic Components, Insurance, Finance, and Computer Services lead in non-IT Investment, while Other Services displaces Finance during the period 1990-95. Communications, Computers, and Computer Services, together with Construction, emerge into the lead after 1995. The second echelon of four industries in at least one subperiod includes six additional industries.

The most important overall conclusion from these results is the domination of IT investment over non-IT investment for the period 1977-2000 as a whole and for the three subperiods 1977-90, 1990-95, and 1995-2000. Our methodology captures this through the use of the concept of the cost of capital. Both IT-producing and IT-using industries have invested substantially in IT and non-IT capital. The IT-producing sectors are among the leading investors in IT capital, but investment in IT is very widespread, encompassing manufacturing, services, utilities, and mining industries. 
Table 11.9

Growth of industry capital input, by subperiod

\begin{tabular}{|c|c|c|c|c|}
\hline Industry name & $1977-2000$ & $1977-90$ & $1990-95$ & 1995-2000 \\
\hline Agriculture & 0.48 & -0.37 & 0.81 & 2.37 \\
\hline Non-energy mining & 1.35 & 0.57 & 1.95 & 2.77 \\
\hline Coal mining & 0.63 & 0.42 & 0.77 & 1.07 \\
\hline Oil and gas mining & 2.47 & 4.35 & -1.54 & 1.60 \\
\hline Construction & 2.27 & 0.04 & 2.11 & 8.23 \\
\hline Lumber, wood, furniture & 1.71 & 1.65 & 0.67 & 2.91 \\
\hline Stone, clay, glass & 1.58 & 1.03 & -1.00 & 5.59 \\
\hline Primary metal & -0.10 & -0.64 & -0.36 & 1.56 \\
\hline Fabricated metal & 2.04 & 1.89 & 1.25 & 3.22 \\
\hline Machinery, excl. computers & 5.37 & 4.81 & 4.95 & 7.25 \\
\hline Computers and office equipment & 4.58 & 3.65 & -3.59 & 15.19 \\
\hline Other electrical machinery & -0.57 & 2.13 & -5.00 & -3.15 \\
\hline Communications equipment & 7.08 & 7.13 & -0.85 & 14.88 \\
\hline Electronic components & 14.90 & 18.59 & 13.86 & 6.33 \\
\hline Motor vehicles & 2.05 & 1.12 & 3.09 & 3.43 \\
\hline Other transportation equipment & 5.66 & 8.60 & -0.73 & 4.39 \\
\hline Instruments and miscellaneous mfg. & 5.40 & 5.64 & 3.77 & 6.42 \\
\hline Food and tobacco & 2.22 & 2.09 & 1.75 & 3.01 \\
\hline Textiles, apparel, leather & 1.22 & 1.05 & 1.95 & 0.94 \\
\hline Paper & 2.97 & 3.80 & 1.86 & 1.92 \\
\hline Printing and publishing & 5.08 & 5.33 & 2.86 & 6.68 \\
\hline Chemicals & 2.83 & 2.61 & 2.93 & 3.29 \\
\hline Petroleum refining & 1.16 & 1.23 & 3.14 & -1.01 \\
\hline Rubber and plastic & 3.97 & 2.93 & 4.71 & 5.94 \\
\hline Transportation & 2.33 & 1.19 & 1.86 & 5.78 \\
\hline Communications & 6.23 & 5.92 & 4.74 & 8.50 \\
\hline Electricity & 2.18 & 3.33 & 0.46 & 0.92 \\
\hline Gas & 2.53 & 2.43 & 2.11 & 3.21 \\
\hline Wholesale trade & 8.98 & 8.78 & 7.44 & 11.04 \\
\hline Retail and eating & 4.74 & 4.70 & 4.28 & 5.32 \\
\hline Finance & 10.61 & 12.10 & 5.76 & 11.60 \\
\hline Insurance & 10.25 & 11.80 & 8.42 & 8.05 \\
\hline Real estate (rental) & 2.47 & 2.78 & 1.46 & 2.68 \\
\hline Computer services & 14.23 & 14.50 & 10.39 & 17.36 \\
\hline Business svc., excl. computer & 9.26 & 8.88 & 2.32 & 17.19 \\
\hline Health, private & 5.86 & 6.04 & 4.79 & 6.46 \\
\hline Legal & 6.12 & 7.91 & 0.86 & 6.72 \\
\hline Education, private & 4.66 & 5.26 & 1.94 & 5.80 \\
\hline Professional and social sves. & 6.94 & 7.38 & 3.83 & 8.90 \\
\hline Other services & 4.37 & 3.80 & 6.09 & 4.13 \\
\hline Government enterprises & 3.09 & 3.26 & 3.08 & 2.64 \\
\hline Household & 3.69 & 3.59 & 2.76 & 4.85 \\
\hline Government, excl. education & 2.83 & 3.35 & 2.35 & 1.98 \\
\hline Government education & 4.13 & 5.47 & 3.35 & 1.40 \\
\hline Average & 4.36 & 4.59 & 2.67 & 5.44 \\
\hline
\end{tabular}

Note: All figures are average annual growth rates. 


\begin{tabular}{|c|c|c|c|c|}
\hline Industry name & 1977-2000 & $1977-90$ & $1990-95$ & 1995-2000 \\
\hline Agriculture & 22.19 & 23.38 & 23.48 & 17.81 \\
\hline Non-energy mining & 24.54 & 24.48 & 34.85 & 14.36 \\
\hline Coal mining & 27.53 & 26.84 & 41.01 & 15.81 \\
\hline Oil and gas mining & 20.16 & 26.28 & 9.44 & 14.95 \\
\hline Construction & 24.28 & 19.02 & 37.54 & 24.72 \\
\hline Lumber, wood, furniture & 19.44 & 21.27 & 15.04 & 19.07 \\
\hline Stone, clay, glass & 13.70 & 12.10 & 6.43 & 25.13 \\
\hline Primary metal & 14.04 & 14.82 & 11.06 & 14.97 \\
\hline Fabricated metal & 20.32 & 22.76 & 16.23 & 18.05 \\
\hline Machinery, excl. computers & 16.72 & 16.38 & 12.83 & 21.51 \\
\hline Computers and office equipment & 15.93 & 15.21 & 4.29 & 29.44 \\
\hline Other electrical machinery & 8.91 & 12.52 & 1.97 & 6.47 \\
\hline Communications equipment & 16.56 & 17.53 & 6.13 & 24.49 \\
\hline Electronic components & 24.38 & 28.98 & 20.84 & 15.94 \\
\hline Motor vehicles & 18.65 & 20.40 & 15.88 & 16.88 \\
\hline Other transportation equipment & 20.88 & 30.16 & -1.20 & 18.82 \\
\hline Instruments and miscellaneous $\mathrm{mfg}$. & 22.52 & 27.90 & 13.47 & 17.59 \\
\hline Food and tobacco & 18.43 & 21.64 & 11.78 & 16.75 \\
\hline Textiles, apparel, leather & 17.06 & 17.14 & 19.23 & 14.69 \\
\hline Paper & 16.61 & 18.93 & 13.11 & 14.09 \\
\hline Printing and publishing & 22.55 & 26.07 & 14.33 & 21.62 \\
\hline Chemicals & 21.79 & 26.26 & 15.18 & 16.81 \\
\hline Petroleum refining & 10.84 & 13.15 & 11.80 & 3.88 \\
\hline Rubber and plastic & 18.79 & 17.42 & 19.35 & 21.81 \\
\hline Transportation & 17.32 & 17.41 & 14.41 & 19.98 \\
\hline Communications & 7.03 & 6.25 & 5.32 & 10.79 \\
\hline Electricity & 18.56 & 28.06 & 3.98 & 8.46 \\
\hline Gas & 25.86 & 38.11 & 11.83 & 8.04 \\
\hline Wholesale trade & 24.13 & 27.44 & 17.92 & 21.75 \\
\hline Retail and eating & 28.79 & 39.00 & 10.24 & 20.82 \\
\hline Finance & 21.97 & 24.55 & 13.07 & 24.18 \\
\hline Insurance & 20.80 & 22.18 & 17.60 & 20.43 \\
\hline Real estate (rental) & 15.29 & 13.32 & 15.51 & 20.20 \\
\hline Computer services & 28.93 & 36.56 & 10.43 & 27.61 \\
\hline Business svc., excl. computer & 23.97 & 30.94 & 2.36 & 27.44 \\
\hline Health, private & 27.45 & 34.78 & 14.33 & 21.51 \\
\hline Legal & 21.61 & 28.37 & 5.00 & 20.65 \\
\hline Education, private & 14.12 & 11.93 & 12.51 & 21.42 \\
\hline Professional and social svcs. & 24.73 & 30.79 & 10.00 & 23.71 \\
\hline Other services & 16.35 & 15.61 & 16.77 & 17.84 \\
\hline Government enterprises & 16.18 & 18.90 & 10.65 & 14.64 \\
\hline Household & 13.99 & 12.06 & 13.54 & 19.46 \\
\hline Government, excl. education & 13.41 & 14.20 & 9.35 & 15.43 \\
\hline Government education & 14.70 & 16.32 & 10.35 & 14.85 \\
\hline Average & 19.36 & 21.99 & 13.62 & 18.29 \\
\hline
\end{tabular}

Note: All figures are average annual growth rates. IT capital includes computer hardware, computer software, and telecommunications equipment. 


\begin{tabular}{|c|c|c|c|c|}
\hline Industry name & $1977-2000$ & 1977-90 & $1990-95$ & $1995-2000$ \\
\hline Agriculture & 0.37 & -0.41 & 0.62 & 2.14 \\
\hline Non-energy mining & 0.97 & 0.45 & 1.12 & 2.18 \\
\hline Coal mining & 0.33 & 0.36 & 0.07 & 0.49 \\
\hline Oil and gas mining & 2.16 & 4.09 & -1.83 & 1.16 \\
\hline Construction & 1.58 & -0.10 & 0.62 & 6.90 \\
\hline Lumber, wood, furniture & 1.14 & 1.19 & 0.11 & 2.03 \\
\hline Stone, clay, glass & 0.63 & 0.02 & -1.48 & 4.32 \\
\hline Primary metal & -0.54 & -1.03 & -0.79 & 0.99 \\
\hline Fabricated metal & 1.20 & 1.25 & 0.26 & 2.04 \\
\hline Machinery, excl. computers & 2.86 & 2.73 & 2.97 & 3.08 \\
\hline Computers and office equipment & 2.07 & 1.56 & -5.56 & 11.02 \\
\hline Other electrical machinery & -2.38 & 0.14 & -6.25 & -5.04 \\
\hline Communications equipment & 5.27 & 5.14 & -2.10 & 12.98 \\
\hline Electronic components & 13.09 & 16.60 & 12.61 & 4.43 \\
\hline Motor vehicles & 1.41 & 0.44 & 2.53 & 2.80 \\
\hline Other transportation equipment & 3.11 & 5.15 & -0.36 & 1.27 \\
\hline Instruments and miscellaneous mfg. & 2.75 & 3.48 & 1.13 & 2.45 \\
\hline Food and tobacco & 1.68 & 1.58 & 1.31 & 2.30 \\
\hline Textiles, apparel, leather & 0.42 & 0.54 & 0.90 & -0.38 \\
\hline Paper & 2.47 & 3.37 & 1.34 & 1.27 \\
\hline Printing and publishing & 2.17 & 3.40 & -0.12 & 1.26 \\
\hline Chemicals & 2.08 & 1.95 & 2.17 & 2.34 \\
\hline Petroleum refining & 0.95 & 1.00 & 2.91 & -1.13 \\
\hline Rubber and plastic & 3.16 & 2.35 & 3.75 & 4.68 \\
\hline Transportation & 1.18 & 0.54 & 0.49 & 3.56 \\
\hline Communications & 5.27 & 5.48 & 4.07 & 5.93 \\
\hline Electricity & 1.57 & 2.52 & 0.21 & 0.49 \\
\hline Gas & 1.24 & 1.27 & 0.40 & 2.03 \\
\hline Wholesale trade & 4.87 & 5.61 & 2.96 & 4.86 \\
\hline Retail and eating & 3.37 & 3.21 & 3.63 & 3.53 \\
\hline Finance & 6.86 & 8.83 & 2.83 & 5.75 \\
\hline Insurance & 7.36 & 9.47 & 5.50 & 3.75 \\
\hline Real estate (rental) & 2.11 & 2.60 & 1.02 & 1.93 \\
\hline Computer services & 8.17 & 6.55 & 10.54 & 10.00 \\
\hline Business svc., excl. computer & 3.10 & 0.93 & 2.47 & 9.82 \\
\hline Health, private & 4.71 & 5.00 & 3.93 & 4.73 \\
\hline Legal & 2.88 & 4.71 & -0.71 & 1.74 \\
\hline Education, private & 3.39 & 4.60 & 0.60 & 3.03 \\
\hline Professional and social svcs. & 4.36 & 4.91 & 2.40 & 4.90 \\
\hline Other services & 3.61 & 3.17 & 5.38 & 3.01 \\
\hline Government enterprises & 1.65 & 2.02 & 1.98 & 0.34 \\
\hline Household & 3.13 & 3.24 & 2.14 & 3.86 \\
\hline Government, excl. education & 1.64 & 2.50 & 1.42 & -0.36 \\
\hline Government education & 2.93 & 4.62 & 2.42 & -0.94 \\
\hline Average & 2.78 & 3.11 & 1.58 & 3.13 \\
\hline
\end{tabular}

Note: All figures are average annual growth rates. 


\subsection{Measuring Labor Input}

Our methodology for deriving labor input was introduced by Jorgenson and Griliches (1995), who constructed an index number of aggregate labor input, based on labor compensation data for male workers, classified by educational attainment. This was extended to the industry level and greatly disaggregated by age, sex, occupation, and class of employment, as well as educational attainment, in Jorgenson, Gollop, and Fraumeni (1987, chap. 3). These labor indexes were updated through 1995 with several important modifications by Ho and Jorgenson (1999). Our major innovation is to incorporate individual data from the CPS for every year between 1977 and 2000.

In this section we describe the construction of labor input indexes by industry, including subindexes for college-educated and non-collegeeducated workers. Our discussion will be brief and concentrate on recent changes in methodology since the overall approach is well known.

To avoid common misunderstandings we first define terms. Following the United Nations (1993) System of National Accounts 1993 we use the terms volume and quantity index interchangeably. Our price index is a "constant quality" price index: the concept of quality is used to distinguish the volume index from a simple sum of hours worked. The term constant quality refers to the assumption that each type of worker has a constant effectiveness over time. The volume index of labor input takes into account the substitutions among different types of workers by weighting the components by their prices. The quality of hours worked is defined as the ratio of the volume of labor input to hours worked.

The concepts of volume and labor quality are useful for avoiding the confusion between substitution and TFP growth. Confusion may arise because the literature on production theory also includes the concept of "labor-augmenting" productivity growth. When productivity growth is labor augmenting, instead of writing the production function as in equation (1), we have

$$
Y_{t}=f\left(K_{t}, A_{t} L_{t}\right)
$$

where $A_{t}$ is the labor-augmentation factor.

One approach to measuring TFP is to use hours worked as an index of labor input $L_{t}$ and calculate changes in the labor-augmentation factor $A_{t}$ from the productivity residual. One might then say that the introduction of a concept of labor quality is a "semantic shift" that amounts to relabeling productivity. This confuses two distinct ideas. We use a constant-quality labor input index $L_{t}$ rather than hours worked and an index of the quality of hours worked as a measure of compositional change. Productivity change is the residual calculated from this labor input index, and there is no separate role for labor-augmenting productivity change, so that no semantic shift is involved. 
Our objective is to construct a measure of labor input that accounts for heterogeneity in hours worked and yet is tractable to implement. We have chosen to classify the workers by sex, age (seven classes), educational attainment (six classes), employment class (two types), and industry as described in table 11A.1. There is a total of $2 \times 7 \times 6 \times 2=168$ types of workers for each of 44 industries. ${ }^{15}$ We focus on 44 industries in this paper, giving a total of $168 \times 44=7,392$ cells. ${ }^{16}$ With this framework in mind, we now describe our implementation, beginning with the notation.

\subsubsection{Notation}

saecj subscripts for sex, age, education, class, industry

$E_{\text {saecj }}$ Employment matrix, number of workers in cell $s, a, e, c, j$

$h_{\text {saecj }}$ Average hours per week in cell $s, a, e, c, j$

$w_{\text {saecj }}$ Average weeks per year in cell $s, a, e, c, j$

$c_{\text {saej }}$ Average hourly compensation of employees in cell $s, a, e, j$

$H_{\text {saecj }}$ hours worked by all workers in cell $s, a, e, c, j$

$H_{l j}$ abbreviation for $H_{\text {saecj }}: l=1$ is $s=1, a=1, e=1, c=1 ; l=2$ is $s=$ $1, a=1, e=1, c=2 \ldots, l=168$ is $s=2, a=7, e=6, c=2$

$L_{l, j} \quad$ labor input of cell $l$ in industry $j$

$P_{L, l, j} \quad$ price of labor input of cell $l$

\subsubsection{Methodology}

We express the industry volume of labor input as a translog index of the individual components:

$$
\Delta \ln L_{j}=\sum_{l} \bar{v}_{l, j} \Delta \ln L_{l, j},
$$

where the $\bar{v}_{l, j}$ weights are the two-period average share of each type of labor in total labor input.

To quantify the impact of substitution among different types of labor input we assume that labor input for each category $\left\{L_{l}\right\}$ is proportional to hours worked $\left\{H_{l}\right\}$ :

$$
L_{l, j}=Q_{l} H_{l, j},
$$

where the constants of proportionality $Q_{l}$ transform hours worked into flows of labor services. We assume that labor services for each category of hours worked are the same at all points of time. For example, an hour

15. This differs from Jorgenson, Gollop, and Fraumeni (1987) in three ways. Jorgenson, Gollop, and Fraumeni show that occupation has little impact when the other dimensions are taken into account, so that we have eliminated this classification. Second, we have eliminated the fourteen-to-fifteen age group, following the official publications of BLS. Third, we have disaggregated the educational group " $4+$ college" into two subgroups, "4 years college" and " $5+$ college."

16. The number of nonzero cells is smaller since the self-employed class is zero for many sectors. 
worked by a self-employed male worker, aged thirty-four, with four years of college education, represents the same labor input in 1977 as in 2000.

Under the assumption in equation (24), the labor quantity index or volume index in equation (23) may be expressed in terms of hours worked:

$$
\Delta \ln L_{j}=\sum_{l} \bar{v}_{l, j} \Delta \ln H_{l, j} .
$$

Observations on the constants $Q_{l}$ are thus not required. The corresponding price of labor input is the ratio of the value of labor compensation to the volume index. The total value is simply

$$
P_{L, j} L_{j}=\sum_{l} P_{L, l, j} L_{l, j} .
$$

Finally, the labor quality index measures the contribution of substitution among the components of labor input to the volume obtained from a given number of hours:

$$
Q_{L, j}=\frac{L_{j}}{H_{j}},
$$

where

$$
H_{j}=\sum_{l} H_{l, j}
$$

is the unweighted sum of hours worked.

To study the relative importance of workers with different levels of educational attainment, we define two further sets of indexes. The labor input of college-educated workers is defined as an aggregate over hours of the educational groups "BA" and "more than BA," while the input of noncollege-educated workers is defined over the remaining groups - "grade 0 8," "some high school," "HS diploma," and "some college no BA." That is,

$$
\begin{aligned}
& \Delta \ln L_{C O, j}=\sum_{s, a, c, e \in\{5,6\}} \bar{v}_{S K s a c c j} \Delta \ln H_{\text {saecj }} \\
& \Delta \ln L_{N C, j}=\sum_{s, a, c, e \notin\{5,6\}} \bar{v}_{U N \text { saecj }} \Delta \ln H_{\text {saec } j}
\end{aligned}
$$

\subsubsection{Data}

The main features of our procedure to construct the $H_{\text {saccj }}$ and $P_{\text {Lsaecj }}$ matrices are the following.

- Detailed cross-classifications by characteristics of individual workers are taken from the Census of Population and the CPS. These data reflect individual incomes. Hours worked and labor compensation in each industry are obtained directly from the NIPAs. These are based on establishment data and reflect payroll records. 
- The observational unit for establishment data is the "job" reflected on a payroll, while the corresponding unit for individual data is the "person." A person may be a "multiple job holder," and a job may be held by more than one person. To link persons and jobs we assemble four matrices of data-compensation, hours worked per week, weeks worked per year, and employment — cross-classified by the characteristics of individual workers.

- The NIPA hours produced by the BEA are adjusted to the BLS Survey of Hours at Work, since hours worked, rather than the hours paid recorded in the establishment data, is the appropriate measure of labor effort.

- Individual data provide estimates of wages, but payroll records also give fringe benefits. Our method requires the price of labor paid by employers, and we therefore scale the wages to total labor compensation in each industry given in the NIPAs.

- Self-employed individuals are a special problem since their labor and property compensation are not reported separately. In this study labor compensation of the self-employed per hour worked is assumed to be equal to that of the employees for each type of worker.

We begin with the public use tapes from the decennial Censuses of Population for 1990, 1980, and 1970, covering 1 percent of the population in 1990 and 1980 and 0.1 percent of the population in 1970. We employ individual observations for about one million workers to construct benchmark matrices of employment $\left(E_{\text {saecj }}\right)$, weekly hours $\left(h_{\text {saecj }}\right)$, weeks per year $\left(w_{\text {saec } j}\right)$, and labor compensation $\left(c_{\text {saej }}\right)$. For each worker, we collect data on age, highest grade completed, class of employment, primary industry of employment, weekly hours worked, weeks worked the previous year, and wage and salary income of employees from the previous year. This data set also provides population weights that allow us to derive national totals. The benchmark matrices are adjusted so that they equal the aggregate tables published by the Bureau of the Census, using the method of iterative proportional fitting described in detail by Jorgenson, Gollop, and Fraumeni (1987, chap. 3, pp. 72-75).

We make some additional refinements to deal with special features of labor data. First, there are multiple job holders working in more than one industry. We use detailed information on this from the May CPS to allocate hours for individual workers among industries and employment classes. Second, information on income is "top-coded." For each industry we fitted a lognormal distribution and used this to estimate the average income for the upper tail of the distribution. Third, the Census of Population for 1990 defines educational attainment as highest degree achieved. We used the estimates in Jaeger (1997) to bridge the new census definition to the old definitions that apply prior to the 1992 data.

In the next step we employ the CPS Annual Demographic File from the 
March surveys to estimate employment, hours, and compensation matrices for each year, again at the individual level. For the years 1977-91 we use the files reorganized by Unicon Research Corporation (2002) so that they have a convenient consistent structure through time. For years after 1991 we use the CPS March files directly. The data after 1991 are based on the new educational classifications of highest degree attained rather than the old classifications, number of years of schooling.

These surveys have sample sizes of about 80,000 workers, only a tenth of the Census of Population. We do not use these annual data to estimate the matrix of 7,392 cells directly, but only to estimate matrices of smaller dimension. For example, for employment we estimate three marginal matrices: (a) matrix with sex, class of employment, age, and education; (b) matrix with sixty-six industries and class of employment; and (c) matrix with nineteen industries and education. For weekly hours and annual weeks we cross-classify by sex, class, age, and ten industries. For hourly compensation of employees we estimate one matrix with sex, age, and education, and another with nineteen industries and education. ${ }^{17}$

Our extension of the industry classification to the IT-producing sectors raises specific issues, since some of them are not explicitly identified in the Census-CPS industry classification. Only one total is given for Electrical Machinery and Equipment; we therefore had to assume the same distribution of characteristics for Communications Equipment, Electronic Components, and Other Electrical Machinery. The data for Computer Services are similarly not separated from Other Business Services prior to 1970. Fortunately, the BLS Industry Output and Employment data include these sectors and provide industry totals.

Our first step is to scale employment, hours, weeks, and compensation matrices based on the March CPS to the BLS annual tabulations based on the monthly CPS. ${ }^{18}$ These matrices are taken as marginal totals to interpolate and extrapolate the 1970, 1980, and 1990 census benchmarks. An initial guess at the full matrix is derived from the nearest two censuses and made consistent with these marginal totals for every year between 1970 and 1990. For years after 1990 we extrapolated the 1990 census in the same way. The census-based matrices are calibrated to the BLS totals for 1970, 1980 and 1990 in order to provide a smooth series. A further refinement would be, for example, to revise the 1981 CPS to take into account the 1980

17. We are able to capture much of the annual variation with these marginal matrices. Of course, we cannot capture as much detail as the census 1 percent sample; for example, we have nineteen industry groupings cross classified by education, one of which is all of mining. Thus, for our forty-four sectors we assume that the education distribution for the three mining sectors is that found in the census but scaled to match the all-mining group.

18. A list of BLS reports is given in appendix A of Jorgenson, Gollop, and Fraumeni (1987). These include Employment and Earnings, Special Labor Force Reports, and BLS Bulletins. Other unpublished tabulations such as the educational attainment of self-employed and unpaid family workers were kindly provided by Tom Hale and Tom Nardone of the BLS. 
census, but this could only be done with detailed information available within the Bureau of the Census.

The CPS covers only the civilian population. For data on military workers we turn to data from the Defense Manpower Data Center, ${ }^{19}$ which provides information on very similar demographic groups. Another detail to note is that the CPS also top-codes the income information. Since 1996 they have provided the average of the top-coded wages, for years prior to 1992 we use the estimates in BLS (1993), appendix table E-1. For the years 1992-95 we use the averages we estimated from the 1990 census.

From the time series of matrices on employment, hours, weeks, and compensation based on individual data we generate a time series based on establishment data given in the NIPAs. The NIPA gives the total number of employees and self-employed for detailed industries. ${ }^{20}$ For the IT sectors not broken out in the NIPAs, these are allocated according to the employment data from the BLS 192-sector data. The number of workers is summed over the detailed sectors so that they match our industry classification for each class of employment, which we denote by $\operatorname{NIPA}(c, j)$. The NIPA does not include unpaid family workers, and these are taken from a separate BLS tabulation. The establishment-based employment matrix, denoted EE, is derived by scaling each part of the individual-based employment $E_{\text {saacj }}$ equally to these NIPA totals:

$$
E_{\text {saecj }} \rightarrow \mathrm{EE}_{\text {saecj }} \text { such that } \sum_{\text {sae }} \mathrm{EE}_{\text {saecj }}=\operatorname{NIPA}(c, j) .
$$

The NIPA gives the total hours worked by employees for fifteen industry groups, which we denote by NIPA_H(IND) ${ }^{21}$ Using the hours and weeks matrices described above we generate the establishment-based hours, denoted HE, on a fifty-two-weeks-per-year basis by scaling to this control total for each industry group:

$$
\begin{gathered}
h_{\text {saecj }}, w_{\text {saecj }} \rightarrow \mathrm{HE}_{\text {saecj }} \ni \sum_{\text {sae }, j \in \mathrm{IND}} 52 \cdot \mathrm{EE}_{\text {saecj }} \mathrm{HE}_{\text {saecj }}=\mathrm{NIPA} \_H(\mathrm{IND}) ; \\
c=\text { employee }
\end{gathered}
$$

For the self-employed and unpaid family workers, the BLS Division of Productivity Research provides an estimate of total nonfarm hours for this group. We scale hours for these workers so that the sum over the nonfarm

19. We thank Mike Dove and Scott Segerman of the Defense Manpower Data Center (DMDC) for making these data available to us.

20. Survey of Current Business, August 2001, tables 6.4C, 6.7C, and 6.8C give the most recent data. The time series is available at http://www.bea.gov. The number of self-employed for each sector is derived from subtracting the number of employees from total workers.

21. See Survey of Current Business, August 2001, table 6.9C. Kurt Kunze kindly provided separate information for total military hours. 
sectors equals this total. For hours in agriculture the Economic Research Service of the U.S. Department of Agriculture provides estimates of total hours. $^{22}$

Finally, we control the compensation matrix to the NIPA's "Compensation of Employees by Industry" and "Wage and Salary by Industry" (Survey of Current Business August 2001, tables 6.2C and 6.3C). We first adjust the labor compensation matrix $\mathbf{c}_{\text {saej }}$ for employees only to the wage and salary totals for each industry. We then impute wage supplements and rescale to the "Compensation" totals, denoted NIPA_ $C$, to get the establishment-based matrix, $\mathbf{C E}$ :

$\mathbf{c}_{\text {saej }} \rightarrow \mathbf{C E}_{\text {saecj }} \ni \sum_{\text {sae }} 52 \cdot \mathrm{EE}_{\text {saecj }} \mathrm{HE}_{\text {saecj }} \mathbf{C E}_{\text {saecj }}=\mathrm{NIPA} C C(j) \quad c=$ employee

For the self-employed and unpaid workers, we set wages equal to those of employees in each category. We then control the sum of capital and labor income to our estimate of proprietor's income as described in section 11.3. Finally, we note one more adjustment to the NIPA data. The BEA revised the industry classification in the NIPAs from the 1972 SIC to the 1987 SIC. To obtain a consistent time series we transformed all the data prior to 1987 to the new basis using the 1987 data for both classifications provided by the BEA.

\subsubsection{Issues}

\section{Level of Classification}

The choice of a classification of workers is a crucial decision. Our classification system gives us a total of 7,392 different types of civilian labor. Characteristics of individual workers we have ignored may be important in assessing labor quality: for example, geographical location, occupation, and work experience. On the other hand, one could object that our system is too detailed to be implemented satisfactorily using the CPS with only 80,000 workers in each yearly sample.

In response to the first objection we note that our characteristics have been used in other studies and have proven to capture the main features of the data at the aggregate level (e.g., BLS 1993). The size of the CPS sample makes further refinement difficult. As for the second objection, we remind the reader that we make use of the decennial census, which provides about one million observations on individual workers. The issue of sample size arises only for the annual CPS, where we are unable to capture year-to-year variation in all the detail available in the censuses. (The BLS [1993] study

22. We are grateful to Larry Rosenblum of the BLS and Eldon Ball of the Department of Agriculture Economic Research Service (ERS) for generously sharing their unpublished data with us. 
uses only the CPS data and roughly the same number of groups-sex, age, educational attainment, experience, and class of employment-but has no industry detail.)

An issue that has vexed labor economists in the United States is the change in educational classification in the CPS in 1992 and in the Census of Population in 1990. Jaeger (1997) has carefully analyzed this problem, and we make use of his tables to construct a bridge to link the new classification to the old. That is, we take the 1992 CPS, bridge it to the old classification, and estimate the change in labor quality between 1990 and 1992. For 1992 onward we use the new educational classification only.

\section{Critiques of the Index Number Approach}

The index number approach to measuring labor input has been subjected to a number of criticisms. One is that a proper measure of labor input should account for intensity of effort, as emphasized by Becker (1985). Intensity of effort is not directly observable. However, we should note that if the intensity of work differs by our demographic categories, and this is captured by some of the observed differences in wages, then intensity of effort is implicitly included in our measures.

The second, more serious, objection to the index number approach is the identification of rates of labor compensation with marginal products. What if these rates reflect "market power" by trade unions rather than productivity of workers? A conceptual approach to this issue is that market power is exercised on the supply side of the labor market by excluding individuals from jobs for which they would otherwise be qualified. This is consistent with price taking by producers demanding labor services and, therefore, with identification of wages with marginal products. A similar issue arises in discrimination by groups of workers who choose to segregate themselves by age, sex, race, or institution of undergraduate origin. Again, firms can be viewed as price takers, as required in modeling producer behavior. ${ }^{23}$

A more subtle criticism of equating compensation with marginal products arises from the "signaling" hypothesis of Spence (1973). The signaling hypothesis has a number of testable empirical implications. Tests like those reported by Kroch and Sjoblom (1994) have provided support for the human capital approach rather than the hypothesis of asymmetric information about ability. For example, Kroch and Sjoblom use two measures of education in modeling wages for individual workers-years of schooling completed and rank in the educational distribution, a proxy for unobserved ability under the signaling hypothesis. Using longitudinal data for individuals, years of schooling clearly dominates rank, which gives some confidence that the distortion due to signaling is small. 


\subsubsection{Results}

Table 11.12 gives the growth rates of labor input, college-educated labor input, and non-college-educated labor input for the period 1977-2000. The growth of labor input is greatest for Computer Services, the IT-producing industry that generates software, and for Other Business Services. These industries also lead in the growth of college-educated and non-collegeeducated labor inputs. Health Services and Professional and Social Services round out the list of four leading industries in the growth of labor input, while the second echelon of four industries includes Legal Services, Private Education, Finance, and Construction. The three remaining ITproducing industries-Computers, Communications Equipment, and Computer Services - all experienced substantial growth in labor input but did not rise to the level of the leading industries. At the other end, the biggest shrinkages in labor input are in Coal Mining, Textiles and Apparel, and Primary Metals.

Growth in college-educated labor input dominates that of non-collegeeducated input for nearly all industries with the exceptions of Legal Services and Public Education. Both college and noncollege labor input decline for Coal Mining, but eighteen of our forty-three industries with labor input reduced labor input for non-college-educated workers (the Household sector is the one industry with no labor input). The list of four leading industries in the growth of college-educated labor input is rounded out by Finance and Other Services, while the remaining leaders in growth of non-college-educated input are Legal and Health Services.

Table 11.13 gives growth rates of labor input for the three subperiods. Computer Services is the leading industry in all three, while Other Business Services leads in two of the three, relinquishing second position in 1990 95 to Motor Vehicles. The four leading industries before 1990 also include Legal and Health Services, while Transportation and Private Education round out the list for 1990-95. The surge in employment after 1995 is led by Communications and Private Education. The second echelon of four industries in at least one subperiod also encompasses six other industries, including Computers and Electronic Components.

Table 11.14 gives growth rates of college-educated labor input for the three subperiods. Computer Services and Other Business Services led before 1990 and after 1995, but Agriculture and Motor Vehicles had the highest growth rates during 1990-95. The list of the top four industries before 1990 includes Health and Legal Services, while Motor Vehicles and Communications joined the list after 1995. During the period 1990-95 the four leading industries also include Computer Services and Rubber and Plastics. The second echelon of four industries in at least one subperiod includes eight other industries, indicating the pervasiveness of growth in college-educated labor input. 


\begin{tabular}{|c|c|c|c|}
\hline Industry name & Total & College & Non-college \\
\hline Agriculture & 0.08 & 2.47 & -0.47 \\
\hline Non-energy mining & -0.74 & 0.17 & -0.94 \\
\hline Coal mining & -4.14 & -3.36 & -4.25 \\
\hline Oil and gas mining & 0.00 & 1.10 & -0.60 \\
\hline Construction & 2.89 & 4.16 & 2.73 \\
\hline Lumber, wood, furniture & 1.32 & 2.82 & 1.11 \\
\hline Stone, clay, glass & 0.24 & 2.19 & -0.07 \\
\hline Primary metal & -1.71 & 0.74 & -2.08 \\
\hline Fabricated metal & 0.43 & 2.09 & 0.18 \\
\hline Machinery, excl. computers & 0.10 & 1.46 & -0.18 \\
\hline Computers and office equipment & 1.11 & 3.47 & -0.39 \\
\hline Other electrical machinery & -0.61 & 1.64 & -1.74 \\
\hline Communications equipment & 1.23 & 3.52 & 0.35 \\
\hline Electronic components & 2.50 & 4.90 & 1.64 \\
\hline Motor vehicles & 0.72 & 3.95 & 0.36 \\
\hline Other transportation equipment & -0.07 & 3.77 & -1.62 \\
\hline Instruments and miscellaneous $\mathrm{mfg}$. & 0.69 & 4.22 & -0.72 \\
\hline Food and tobacco & -0.01 & 2.72 & -0.33 \\
\hline Textiles, apparel, leather & -2.35 & 0.32 & -2.78 \\
\hline Paper & 0.39 & 2.48 & -0.04 \\
\hline Printing and publishing & 1.92 & 4.71 & 0.88 \\
\hline Chemicals & 0.58 & 3.27 & -0.74 \\
\hline Petroleum refining & -1.43 & 0.13 & -2.18 \\
\hline Rubber and plastic & 1.75 & 3.36 & 1.42 \\
\hline Transportation & 2.47 & 5.60 & 1.92 \\
\hline Communications & 1.98 & 5.55 & 0.67 \\
\hline Electricity & 0.36 & 3.67 & -0.86 \\
\hline Gas & -0.99 & 1.85 & -2.00 \\
\hline Wholesale trade & 1.76 & 3.00 & 1.28 \\
\hline Retail and eating & 1.68 & 3.32 & 1.33 \\
\hline Finance & 3.68 & 6.08 & 1.22 \\
\hline Insurance & 1.73 & 3.04 & 0.86 \\
\hline Real estate (rental) & 2.25 & 3.28 & 1.64 \\
\hline Computer services & 10.97 & 12.48 & 9.52 \\
\hline Business svc., excl. computer & 6.08 & 6.70 & 5.87 \\
\hline Health, private & 4.54 & 5.43 & 3.81 \\
\hline Legal & 3.69 & 3.76 & 3.95 \\
\hline Education, private & 3.68 & 4.27 & 2.20 \\
\hline Professional and social svcs. & 3.95 & 4.83 & 2.87 \\
\hline Other services & 2.66 & 5.96 & 2.15 \\
\hline Government enterprises & 1.41 & 3.42 & 0.96 \\
\hline Household & 0.00 & 0.00 & 0.00 \\
\hline Government, excl. education & 0.95 & 3.69 & -1.32 \\
\hline Government education & 1.83 & 0.83 & 4.09 \\
\hline Average & 1.38 & 3.33 & 0.69 \\
\hline
\end{tabular}

Note: All figures are average annual growth rates. 
Table 11.13 Growth of labor input, by subperiod

\begin{tabular}{|c|c|c|c|c|}
\hline Industry name & $1977-2000$ & $1977-90$ & $1990-95$ & 1995-2000 \\
\hline Agriculture & 0.08 & -0.23 & 1.26 & -0.33 \\
\hline Non-energy mining & -0.74 & -0.52 & -0.42 & -1.64 \\
\hline Coal mining & -4.14 & -2.59 & -5.69 & -6.59 \\
\hline Oil and gas mining & 0.00 & 1.82 & -2.53 & -2.19 \\
\hline Construction & 2.89 & 2.83 & 1.39 & 4.56 \\
\hline Lumber, wood, furniture & 1.32 & 0.86 & 1.83 & 2.01 \\
\hline Stone, clay, glass & 0.24 & -0.56 & 0.50 & 2.08 \\
\hline Primary metal & -1.71 & -2.96 & -0.55 & 0.37 \\
\hline Fabricated metal & 0.43 & -0.35 & 1.06 & 1.81 \\
\hline Machinery, excl. computers & 0.10 & -0.65 & 1.54 & 0.62 \\
\hline Computers and office equipment & 1.11 & 3.52 & -3.97 & -0.07 \\
\hline Other electrical machinery & -0.61 & -0.96 & -0.04 & -0.27 \\
\hline Communications equipment & 1.23 & 1.57 & 0.88 & 0.68 \\
\hline Electronic components & 2.50 & 2.85 & 0.73 & 3.38 \\
\hline Motor vehicles & 0.72 & -0.87 & 4.21 & 1.36 \\
\hline Other transportation equipment & -0.07 & 2.05 & -6.87 & 1.20 \\
\hline Instruments and miscellaneous $\mathrm{mfg}$. & 0.69 & 0.96 & -0.41 & 1.08 \\
\hline Food and tobacco & -0.01 & -0.39 & 0.62 & 0.34 \\
\hline Textiles, apparel, leather & -2.35 & -1.79 & -0.55 & -5.61 \\
\hline Paper & 0.39 & 0.79 & 0.57 & -0.82 \\
\hline Printing and publishing & 1.92 & 2.94 & 1.14 & 0.04 \\
\hline Chemicals & 0.58 & 0.80 & 0.00 & 0.57 \\
\hline Petroleum refining & -1.43 & -1.21 & -0.88 & -2.56 \\
\hline Rubber and plastic & 1.75 & 1.74 & 2.64 & 0.88 \\
\hline Transportation & 2.47 & 2.00 & 3.77 & 2.39 \\
\hline Communications & 1.98 & 1.12 & 1.34 & 4.85 \\
\hline Electricity & 0.36 & 2.03 & -1.45 & -2.17 \\
\hline Gas & -0.99 & -0.23 & -0.52 & -3.42 \\
\hline Wholesale trade & 1.76 & 2.12 & 1.11 & 1.48 \\
\hline Retail and eating & 1.68 & 1.86 & 1.41 & 1.46 \\
\hline Finance & 3.68 & 4.41 & 1.56 & 3.90 \\
\hline Insurance & 1.73 & 2.65 & 0.11 & 0.93 \\
\hline Real estate (rental) & 2.25 & 2.94 & 1.00 & 1.70 \\
\hline Computer services & 10.97 & 12.25 & 5.48 & 13.14 \\
\hline Business svc., excl. computer & 6.08 & 7.02 & 3.59 & 6.12 \\
\hline Health, private & 4.54 & 5.64 & 3.13 & 3.08 \\
\hline Legal & 3.69 & 6.77 & -0.55 & -0.09 \\
\hline Education, private & 3.68 & 3.25 & 3.66 & 4.79 \\
\hline Professional and social svcs. & 3.95 & 4.18 & 3.08 & 4.23 \\
\hline Other services & 2.66 & 3.17 & 1.87 & 2.13 \\
\hline Government enterprises & 1.41 & 2.34 & 0.37 & 0.05 \\
\hline Household & 0.00 & 0.00 & 0.00 & 0.00 \\
\hline Government, excl. education & 0.95 & 1.77 & -0.60 & 0.36 \\
\hline Government education & 1.83 & 1.48 & 2.24 & 2.30 \\
\hline Average & 1.38 & 1.78 & 0.63 & 1.12 \\
\hline
\end{tabular}

Note: All figures are average annual growth rates. 


\begin{tabular}{|c|c|c|c|c|}
\hline Industry name & $1977-2000$ & $1977-90$ & $1990-95$ & $1995-2000$ \\
\hline Agriculture & 2.47 & 3.95 & 6.10 & -5.01 \\
\hline Non-energy mining & 0.17 & 1.50 & 2.95 & -6.09 \\
\hline Coal mining & -3.36 & -0.08 & -2.75 & -12.50 \\
\hline Oil and gas mining & 1.10 & 4.04 & 0.64 & -6.07 \\
\hline Construction & 4.16 & 5.90 & 0.68 & 3.08 \\
\hline Lumber, wood, furniture & 2.82 & 2.44 & 2.21 & 4.41 \\
\hline Stone, clay, glass & 2.19 & 1.63 & 1.22 & 4.61 \\
\hline Primary metal & 0.74 & 0.72 & -0.60 & 2.15 \\
\hline Fabricated metal & 2.09 & 2.00 & 0.16 & 4.27 \\
\hline Machinery, excl. computers & 1.46 & 1.29 & 2.80 & 0.59 \\
\hline Computers and office equipment & 3.47 & 7.38 & -2.71 & -0.52 \\
\hline Other electrical machinery & 1.64 & 1.99 & 2.05 & 0.33 \\
\hline Communications equipment & 3.52 & 4.47 & 3.69 & 0.88 \\
\hline Electronic components & 4.90 & 5.51 & 3.51 & 4.73 \\
\hline Motor vehicles & 3.95 & 2.37 & 5.62 & 6.37 \\
\hline Other transportation equipment & 3.77 & 7.11 & -5.69 & 4.53 \\
\hline Instruments and miscellaneous mfg. & 4.22 & 4.80 & 2.12 & 4.79 \\
\hline Food and tobacco & 2.72 & 3.15 & 2.88 & 1.44 \\
\hline Textiles, apparel, leather & 0.32 & 1.29 & 2.63 & -4.55 \\
\hline Paper & 2.48 & 3.24 & 3.64 & -0.64 \\
\hline Printing and publishing & 4.71 & 6.41 & 4.43 & 0.55 \\
\hline Chemicals & 3.27 & 4.34 & 2.80 & 0.94 \\
\hline Petroleum refining & 0.13 & 0.83 & 1.30 & -2.86 \\
\hline Rubber and plastic & 3.36 & 3.37 & 5.04 & 1.67 \\
\hline Transportation & 5.60 & 7.17 & 4.52 & 2.58 \\
\hline Communications & 5.55 & 6.07 & 3.62 & 6.10 \\
\hline Electricity & 3.67 & 6.25 & 0.74 & -0.13 \\
\hline Gas & 1.85 & 3.27 & 1.50 & -1.47 \\
\hline Wholesale trade & 3.00 & 4.58 & 0.36 & 1.54 \\
\hline Retail and eating & 3.32 & 4.49 & 0.32 & 3.30 \\
\hline Finance & 6.08 & 7.76 & 2.87 & 4.90 \\
\hline Insurance & 3.04 & 4.78 & 0.97 & 0.55 \\
\hline Real estate (rental) & 3.28 & 5.19 & 0.86 & 0.74 \\
\hline Computer services & 12.48 & 14.62 & 5.57 & 13.83 \\
\hline Business svc., excl. computer & 6.70 & 8.23 & 2.32 & 7.10 \\
\hline Health, private & 5.43 & 7.40 & 2.30 & 3.44 \\
\hline Legal & 3.76 & 7.28 & -1.00 & -0.62 \\
\hline Education, private & 4.27 & 4.07 & 3.73 & 5.34 \\
\hline Professional and social svcs. & 4.83 & 5.44 & 3.10 & 4.95 \\
\hline Other services & 5.96 & 6.99 & 3.74 & 5.51 \\
\hline Government enterprises & 3.42 & 5.45 & -0.65 & 2.20 \\
\hline Household & 0.00 & 0.00 & 0.00 & 0.00 \\
\hline Government, excl. education & 3.69 & 5.89 & 0.16 & 1.48 \\
\hline Government education & 0.83 & -0.52 & 1.68 & 3.51 \\
\hline Average & 3.33 & 4.51 & 1.89 & 1.67 \\
\hline
\end{tabular}

Note: All figures are average annual growth rates. 
Finally, table 11.15 gives growth rates of non-college-educated labor input for the three subperiods. Service industries head the list before 1990Computer Services, Other Business Services, Public Education, and Legal Services. Computer Services and Other Business Services also lead during 1990-95 and 1995-2000, but Motor Vehicles and Health Services follow immediately afterward during 1990-95, and Construction and Communications follow during 1995-2000. As before, the second echelon of four industries in at least one period is a lengthy one and includes four additional industries.

The most important overall conclusion from these results is the domination of college-educated over non-college-educated labor input in the growth of employment for the period 1977-2000 as a whole and for the three subperiods 1977-90, 1990-95, and 1995-2000. While many industries have reduced non-college-educated labor input during this period, most have added college-educated workers. Our methodology captures the impacts of this ongoing restructuring of the labor force by weighting hours worked for each type of labor input by labor compensation per hour. Massive investments in higher education by college-educated workers before they enter the labor force are obviously essential prerequisites for this ongoing transformation of the work force.

\subsection{Measuring Industry Productivity}

We now examine the sources of U.S. economic growth at the industry level. The contributions of capital and labor inputs and gains in aggregate TFP discussed in section 11.1 ultimately reflect the evolution of the production structure at the industry level, and it is critical to examine the component industries. Changes in this production structure cumulate into the determinants of economic growth as technologies evolve, and prices and economic incentives are altered accordingly.

\subsubsection{Methodology}

Our methodology for measuring TFP at the industry level begins with an industry production function:

$$
Y_{j}=f\left(K_{j}, L_{j}, X_{j}, T\right)
$$

where $Y$ is industry output, ${ }^{24} \mathrm{~K}$ is capital input, $L$ is labor input, $X$ is intermediate input, and $T$ is an indicator of efficiency, all for industry $j$. The variables $K, L$, and $X$ are each aggregates of the many components described in the preceding sections, and the production function in equation (30) is assumed to be separable in these components.

24. We refer to this simply as "output," although the term gross output is sometimes used to distinguish this measure from value added. 


\begin{tabular}{|c|c|c|c|c|}
\hline Industry name & $1977-2000$ & $1977-90$ & $1990-95$ & 1995-2000 \\
\hline Agriculture & -0.47 & -1.17 & -0.31 & 1.18 \\
\hline Non-energy mining & -0.94 & -0.97 & -1.25 & -0.54 \\
\hline Coal mining & -4.25 & -2.95 & -6.18 & -5.69 \\
\hline Oil and gas mining & -0.60 & 0.60 & -4.73 & 0.42 \\
\hline Construction & 2.73 & 2.41 & 1.49 & 4.79 \\
\hline Lumber, wood, furniture & 1.11 & 0.66 & 1.78 & 1.61 \\
\hline Stone, clay, glass & -0.07 & -0.88 & 0.37 & 1.59 \\
\hline Primary metal & -2.08 & -3.46 & -0.53 & -0.05 \\
\hline Fabricated metal & 0.18 & -0.68 & 1.23 & 1.38 \\
\hline Machinery, excl. computers & -0.18 & -1.01 & 1.14 & 0.67 \\
\hline Computers and office equipment & -0.39 & 1.20 & -5.58 & 0.67 \\
\hline Other electrical machinery & -1.74 & -2.24 & -1.59 & -0.58 \\
\hline Communications equipment & 0.35 & 0.53 & -0.44 & 0.67 \\
\hline Electronic components & 1.64 & 1.91 & -0.50 & 3.09 \\
\hline Motor vehicles & 0.36 & -1.14 & 4.03 & 0.61 \\
\hline Other transportation equipment & -1.62 & 0.51 & -7.66 & -1.10 \\
\hline Instruments and miscellaneous mfg. & -0.72 & -0.21 & -1.66 & -1.10 \\
\hline Food and tobacco & -0.33 & -0.74 & 0.22 & 0.19 \\
\hline Textiles, apparel, leather & -2.78 & -2.17 & -1.24 & -5.90 \\
\hline Paper & -0.04 & 0.38 & -0.29 & -0.88 \\
\hline Printing and publishing & 0.88 & 1.87 & -0.57 & -0.26 \\
\hline Chemicals & -0.74 & -0.68 & -1.91 & 0.30 \\
\hline Petroleum refining & -2.18 & -2.03 & -2.40 & -2.35 \\
\hline Rubber and plastic & 1.42 & 1.46 & 2.06 & 0.68 \\
\hline Transportation & 1.92 & 1.11 & 3.59 & 2.37 \\
\hline Communications & 0.67 & -0.45 & 0.12 & 4.12 \\
\hline Electricity & -0.86 & 0.75 & -2.54 & -3.35 \\
\hline Gas & -2.00 & -1.29 & -1.43 & -4.42 \\
\hline Wholesale trade & 1.28 & 1.11 & 1.52 & 1.48 \\
\hline Retail and eating & 1.33 & 1.34 & 1.72 & 0.91 \\
\hline Finance & 1.22 & 1.72 & -0.46 & 1.59 \\
\hline Insurance & 0.86 & 1.31 & -0.63 & 1.19 \\
\hline Real estate (rental) & 1.64 & 1.49 & 0.95 & 2.72 \\
\hline Computer services & 9.52 & 9.94 & 5.65 & 12.29 \\
\hline Business svc., excl. computer & 5.87 & 6.45 & 4.50 & 5.73 \\
\hline Health, private & 3.81 & 4.30 & 3.80 & 2.54 \\
\hline Legal & 3.95 & 5.51 & 2.18 & 1.68 \\
\hline Education, private & 2.20 & 1.41 & 3.32 & 3.16 \\
\hline Professional and social svcs. & 2.87 & 2.75 & 3.09 & 2.95 \\
\hline Other services & 2.15 & 2.66 & 1.47 & 1.50 \\
\hline Government enterprises & 0.96 & 1.63 & 0.65 & -0.49 \\
\hline Household & 0.00 & 0.00 & 0.00 & 0.00 \\
\hline Government, excl. education & -1.32 & -1.39 & -1.44 & -1.03 \\
\hline Government education & 4.09 & 5.61 & 2.98 & 1.25 \\
\hline Average & 0.69 & 0.86 & 0.11 & 0.83 \\
\hline
\end{tabular}

Note: All figures are average annual growth rates. 
Let $P_{Y j}, P_{K, j}, P_{L, j}$, and $P_{X, j}$ denote the prices for outputs and the three inputs, respectively. Under the assumptions of constant returns to scale and competitive markets, a translog index of TFP growth is defined as

$$
v_{T, j} \equiv \Delta \ln Y_{j}-\bar{v}_{K, j} \Delta \ln K_{j}-\bar{v}_{L, j} \Delta \ln L_{j}-\bar{v}_{X, j} \Delta \ln X_{j},
$$

where $\bar{v}$ is the two-period average share of the subscripted input in the value of nominal output. Note that the assumptions imply that value of output is equal to the sum of outlays on all inputs, so that $P_{Y, j} Y_{j}=P_{K, j} K_{j}+P_{L, j} L_{j}$ $+P_{X, j} X_{j}$ and the value shares sum to $1.0 .^{25}$

Equation (4) provides an alternative definition in terms of value added:

$$
v_{T, j} \equiv \bar{v}_{V, j} \Delta \ln V_{j}-\bar{v}_{K, j} \Delta \ln K_{j}-\bar{v}_{L, j} \Delta \ln L_{j} .
$$

While useful for aggregation purposes, this definition fails to identify the role of intermediate inputs, such as semiconductors used in producing computers and communications equipment. The definition of industrylevel TFP growth in equation (31) is more useful for this purpose and will be employed in our study of growth of individual industries.

Under the same assumptions as in equation (31), we decompose industry labor productivity growth, or growth of output per hour worked, as

$$
\Delta \ln y_{j}=\bar{v}_{K, j} \Delta \ln k_{j}+\bar{v}_{L, j} \Delta \ln Q_{L, j}+\bar{v}_{X, j} \Delta \ln x_{j}+v_{T, j},
$$

where lowercase letters refer to output and inputs per hour worked. The terms on the right-hand side are, respectively, the contributions of capital deepening, labor quality, intermediate input deepening, and TFP growth to growth of labor productivity. We refer to equation (31) as TFP growth or productivity growth, and equation (33) as labor productivity growth.

\subsubsection{Results}

Table 11.16 presents the sources of growth for each industry based on equation (31), where the growth of output is the sum of the contributions of capital, labor, and intermediate inputs and TFP growth. An important feature of our methodology is the explicit role provided for intermediate inputs. Consider, for example, the output of the semiconductor industry. Much of this output is invisible at the aggregate level, because semiconductor products are mainly inputs into other industries rather than deliveries to final demand as consumption and investment goods. Semiconductor inputs, however, play a key role in the improvements in the quality and performance of computers, communications equipment, instruments, and a host of other products. ${ }^{26}$

More specifically, semiconductors are an output of Electronic Compo-

25. See Hall (1988), Basu and Fernald (1995, 1997), and Basu, Fernald, and Shapiro (2001) for alternative assumptions and their implications.

26. See Dulberger (1993), Triplett (1996), and Oliner and Sichel (2002) for details. 


\begin{tabular}{|c|c|c|c|c|c|}
\hline \multirow[b]{2}{*}{ Industry name } & \multirow[b]{2}{*}{ Output } & \multicolumn{3}{|c|}{ Input contributions } & \multirow[b]{2}{*}{ TFP } \\
\hline & & Capital & Labor & Intermediate & \\
\hline Agriculture & 2.40 & 0.08 & 0.04 & 0.38 & 1.90 \\
\hline Non-energy mining & 1.53 & 0.34 & -0.28 & 0.65 & 0.82 \\
\hline Coal mining & 1.89 & 0.24 & -1.37 & 0.26 & 2.77 \\
\hline Oil and gas mining & -0.32 & 1.09 & -0.01 & -0.30 & -1.10 \\
\hline Construction & 1.65 & 0.14 & 1.12 & 1.47 & -1.08 \\
\hline Lumber, wood, furniture & 2.00 & 0.18 & 0.38 & 1.13 & 0.31 \\
\hline Stone, clay, glass & 1.65 & 0.24 & 0.08 & 0.89 & 0.44 \\
\hline Primary metal & 0.22 & -0.03 & -0.28 & -0.34 & 0.87 \\
\hline Fabricated metal & 1.98 & 0.26 & 0.11 & 1.17 & 0.45 \\
\hline Machinery, excl. computers & 1.40 & 0.63 & 0.01 & 1.28 & -0.52 \\
\hline Computers and office equipment & 23.70 & 0.53 & 0.33 & 9.96 & 12.87 \\
\hline Other electrical machinery & 2.28 & -0.06 & -0.20 & 1.70 & 0.84 \\
\hline Communications equipment & 8.73 & 1.87 & 0.38 & 4.77 & 1.70 \\
\hline Electronic components & 18.15 & 1.99 & 0.93 & 5.56 & 9.67 \\
\hline Motor vehicles & 2.60 & 0.15 & 0.07 & 2.45 & -0.07 \\
\hline Other transportation equipment & 2.32 & 0.33 & -0.06 & 1.64 & 0.40 \\
\hline Instruments and miscellaneous mfg. & 3.25 & 0.57 & 0.30 & 2.03 & 0.35 \\
\hline Food and tobacco & 1.60 & 0.27 & 0.00 & 0.90 & 0.43 \\
\hline Textiles, apparel, leather & 0.33 & 0.10 & -0.66 & -0.20 & 1.10 \\
\hline Paper & 1.64 & 0.38 & 0.09 & 0.96 & 0.21 \\
\hline Printing and publishing & 2.06 & 0.72 & 0.78 & 1.09 & -0.53 \\
\hline Chemicals & 1.45 & 0.55 & 0.12 & 0.86 & -0.09 \\
\hline Petroleum refining & 0.47 & 0.08 & -0.07 & 0.95 & -0.49 \\
\hline Rubber and plastic & 3.61 & 0.41 & 0.58 & 1.33 & 1.29 \\
\hline Transportation & 2.76 & 0.35 & 0.92 & 1.35 & 0.15 \\
\hline Communications & 4.48 & 1.91 & 0.48 & 1.99 & 0.09 \\
\hline Electricity & 2.17 & 0.89 & 0.05 & 0.88 & 0.34 \\
\hline Gas & -1.87 & 0.42 & -0.09 & -1.30 & -0.90 \\
\hline Wholesale trade & 4.33 & 1.53 & 0.83 & 0.88 & 1.09 \\
\hline Retail and eating & 2.65 & 0.57 & 0.78 & 1.21 & 0.09 \\
\hline Finance & 7.72 & 2.80 & 1.26 & 3.04 & 0.61 \\
\hline Insurance & 2.29 & 1.30 & 0.64 & 2.06 & -1.71 \\
\hline Real estate (rental) & 2.74 & 1.59 & 0.27 & 0.68 & 0.21 \\
\hline Computer services & 13.52 & 3.38 & 4.19 & 5.98 & -0.03 \\
\hline Business svc., excl. computer & 5.16 & 1.75 & 3.11 & 0.69 & -0.39 \\
\hline Health, private & 3.18 & 0.53 & 2.63 & 1.52 & -1.50 \\
\hline Legal & 1.86 & 0.94 & 1.82 & 0.22 & -1.11 \\
\hline Education, private & 2.45 & 0.14 & 1.98 & 1.21 & -0.87 \\
\hline Professional and social svcs. & 4.36 & 1.31 & 1.87 & 1.45 & -0.26 \\
\hline Other services & 3.29 & 0.66 & 1.06 & 1.59 & -0.01 \\
\hline Government enterprises & 2.46 & 0.83 & 0.54 & 1.08 & 0.01 \\
\hline Household & 3.69 & 3.69 & 0.00 & 0.00 & 0.00 \\
\hline Government, excl. education & 1.38 & 0.76 & 0.62 & 0.00 & 0.00 \\
\hline Government education & 2.13 & 0.51 & 1.62 & 0.00 & 0.00 \\
\hline
\end{tabular}

Notes: Output and total factor productivity (TFP) are average annual growth rates. Capital, labor, and intermediate inputs are average annual contributions (share-weighted growth rates). 
nents but appear as intermediate inputs into Computers, Communications Equipment, and other industries. Price declines resulting from improvements in semiconductor technology are reflected in the large contributions of intermediate inputs in the industries that consume semiconductors. By accurately accounting for intermediate inputs through the use of interindustry transactions tables we can allocate U.S. economic growth to its sources in individual industries.

The considerable impact of intermediate inputs on the growth of industry output is strikingly apparent in table 11.16. Intermediate input is the key contributor to the growth of output in Computers and Communications Equipment, as well as Computer Services (which produces software) and the Electronic Components industry. Intermediate input makes negative contributions to growth in Oil and Gas Mining; Primary Metal; Textiles, Apparel, and Leather; and Gas Utilities. The important role of intermediate input is entirely suppressed by using value added, rather than output, as a measure of activity at the industry level. We conclude that an approach based on equation (31) should be used wherever possible, as recommended by Schreyer (2001).

Investments in tangible assets and human capital are very important contributors to the growth of output. The contributions of capital input are positive for every industry, except Other Electrical Machinery, reflecting the decline in the low-end items like radios and TVs. Ignoring private households, which by definition have the largest contribution of capital input, the sectors where capital input are particularly significant are Computer Services, Finance, and Electronic Components. Labor input makes large positive contributions to Computer Services, Other Business Services, Health Services, and Private Education. The contributions of labor input are negative for nine industries; the sharpest declines are in Coal Mining and in Textiles, Apparel, and Leather. Since labor input is an important source of aggregate economic growth, these are outweighed by positive contributions from the remaining thirty-two industries.

The final factor for the growth of output identified in table 11.16 is TFP growth. Computers and Electronic Components have the most dramatic contributions of TFP growth, where it accounts for about half of the output growth in these two industries. Productivity growth is also relatively important in Communications Equipment, but Computer Services, the remaining IT-producing industry, had negative productivity growth throughout the period 1977-2000. Coal Mining outranks both of these industries in terms of productivity growth. Sixteen of the forty-one industries with nonzero productivity growth have negative contributions of productivity growth throughout the period. The perplexing phenomenon of negative productivity growth at the industry level was a primary motivation for the path-breaking research of Corrado and Slifman (1999) and Gullickson and Harper (1999). 
One possible interpretation of negative TFP growth is a failure to account for changes in quality in the measurement of output. If price increases were systematically overstated due to a failure to hold quality constant, the growth of output and TFP would be correspondingly understated. An alternative and equally plausible explanation is that growth cannot be identified with changes in technology but rather reflects the growth of inputs. In this view, negative productivity growth reflects worsening productive efficiency due to such factors as rising barriers to entry, growing inflexibility in the allocation of labor, and health and safety regulations. Sorting out these alternatives remains a research topic of considerable importance.

In addition to TFP, equation (33) outlines a methodology for analyzing the sources of labor productivity growth in terms of capital and input deepening, and labor quality. Capital deepening is defined in the same way as at the aggregate level, and intermediate deepening is defined analogously. The contribution of labor quality to labor productivity growth is the product of the value share of labor and the growth rate of labor input per hour worked. Finally, TFP growth contributes point for point to labor productivity growth.

Our decomposition of industry labor productivity growth for the period 1977-2000 is given in table 11.17. Labor productivity is defined simply as output per hour worked, so the rate of growth of output is the sum of the rates of growth of labor productivity and hours worked. Computers and Electronic Components have the highest growth rates of labor productivity for the period 1977-2000, as well as the highest growth rates of output. Communications Equipment and Coal Mining also have relative high labor productivity growth. Construction, an industry that has long puzzled productivity analysts (e.g., Baily and Gordon 1988), has a negative rate of labor productivity growth, but this is also true of Gas Utilities and Other Business Services, as well as Health, Legal, and Private Education Services.

The contribution of capital deepening to labor productivity growth is positive for all industries except Construction, Finance, Electronic Components, Communications Equipment, and Coal Mining lead the list of industries with positive capital deepening. The contribution of intermediate deepening is positive for most sectors; the exceptions are Construction, Gas Utilities, Other Business Services, Legal Services, and Private Education. The contribution of labor quality reflects increases in the proportion of workers with higher marginal products and is negative for only three industries-Insurance, Other Business Services, and Legal Services.

We have analyzed the role of TFP growth as a source of industry output growth in detail above. Table 11.18 provides growth rates of productivity for forty-one industries for the periods 1977-2000 and the subperiods 1977-90, 1990-95, and 1995-2000. During the resurgence of economic growth after 1995, Electronic Components and Computers achieve double-digit growth 


\begin{tabular}{|c|c|c|c|c|c|}
\hline Industry name & ALP & $\begin{array}{c}\text { Capital } \\
\text { deepening }\end{array}$ & $\begin{array}{c}\text { Intermediate } \\
\text { deepening }\end{array}$ & $\begin{array}{l}\text { Labor } \\
\text { quality }\end{array}$ & TFP \\
\hline Agriculture & 3.02 & 0.21 & 0.76 & 0.14 & 1.90 \\
\hline Non-energy mining & 2.70 & 0.63 & 1.11 & 0.14 & 0.82 \\
\hline Coal mining & 6.68 & 1.48 & 2.21 & 0.23 & 2.77 \\
\hline Oil and gas mining & 0.38 & 1.11 & 0.28 & 0.09 & -1.10 \\
\hline Construction & -1.02 & -0.02 & -0.01 & 0.09 & -1.08 \\
\hline Lumber, wood, furniture & 1.17 & 0.07 & 0.65 & 0.15 & 0.31 \\
\hline Stone, clay, glass & 1.82 & 0.24 & 0.99 & 0.15 & 0.44 \\
\hline Primary metal & 2.36 & 0.20 & 1.21 & 0.08 & 0.87 \\
\hline Fabricated metal & 1.91 & 0.23 & 1.12 & 0.11 & 0.45 \\
\hline Machinery, excl. computers & 1.69 & 0.65 & 1.42 & 0.14 & -0.52 \\
\hline Computers and office equipment & 22.62 & 0.28 & 9.46 & 0.02 & 12.87 \\
\hline Other electrical machinery & 3.30 & 0.05 & 2.27 & 0.13 & 0.84 \\
\hline Communications equipment & 7.76 & 1.70 & 4.29 & 0.07 & 1.70 \\
\hline Electronic components & 15.98 & 1.74 & 4.46 & 0.11 & 9.67 \\
\hline Motor vehicles & 2.02 & 0.10 & 1.98 & 0.02 & -0.07 \\
\hline Other transportation equipment & 2.48 & 0.34 & 1.70 & 0.04 & 0.40 \\
\hline Instruments and miscellaneous mfg. & 3.16 & 0.57 & 1.98 & 0.27 & 0.35 \\
\hline Food and tobacco & 1.81 & 0.28 & 1.06 & 0.03 & 0.43 \\
\hline Textiles, apparel, leather & 3.12 & 0.32 & 1.59 & 0.12 & 1.10 \\
\hline Paper & 1.76 & 0.40 & 1.03 & 0.13 & 0.21 \\
\hline Printing and publishing & 0.55 & 0.50 & 0.41 & 0.17 & -0.53 \\
\hline Chemicals & 1.47 & 0.55 & 0.89 & 0.13 & -0.09 \\
\hline Petroleum refining & 2.28 & 0.21 & 2.53 & 0.02 & -0.49 \\
\hline Rubber and plastic & 2.18 & 0.26 & 0.52 & 0.11 & 1.29 \\
\hline Transportation & 0.57 & 0.03 & 0.28 & 0.10 & 0.15 \\
\hline Communications & 2.92 & 1.44 & 1.28 & 0.11 & 0.09 \\
\hline Electricity & 2.18 & 1.00 & 0.78 & 0.07 & 0.34 \\
\hline Gas & -0.64 & 0.68 & -0.44 & 0.02 & -0.90 \\
\hline Wholesale trade & 2.81 & 1.27 & 0.33 & 0.12 & 1.09 \\
\hline Retail and eating & 1.10 & 0.38 & 0.56 & 0.06 & 0.09 \\
\hline Finance & 5.02 & 2.10 & 1.97 & 0.34 & 0.61 \\
\hline Insurance & 0.47 & 1.06 & 1.15 & -0.03 & -1.71 \\
\hline Real estate (rental) & 0.46 & 0.12 & 0.14 & 0.00 & 0.21 \\
\hline Computer services & 2.83 & 0.78 & 1.98 & 0.12 & -0.03 \\
\hline Business svc., excl. computer & -0.99 & 0.53 & -1.11 & -0.03 & -0.39 \\
\hline Health, private & -0.48 & 0.20 & 0.32 & 0.51 & -1.50 \\
\hline Legal & -1.84 & 0.38 & -1.03 & -0.08 & -1.11 \\
\hline Education, private & -0.38 & 0.05 & -0.01 & 0.45 & -0.87 \\
\hline Professional and social svcs. & 0.99 & 0.67 & 0.31 & 0.27 & -0.26 \\
\hline Other services & 0.67 & 0.27 & 0.40 & 0.02 & -0.01 \\
\hline Government enterprises & 1.52 & 0.57 & 0.75 & 0.18 & 0.01 \\
\hline Household & 3.69 & 3.69 & 0.00 & 0.00 & 0.00 \\
\hline Government, excl. education & 1.40 & 0.72 & 0.00 & 0.68 & 0.00 \\
\hline Government education & 0.25 & 0.31 & 0.00 & -0.06 & 0.00 \\
\hline
\end{tabular}

Notes: Average labor productivity (ALP) and total factor productivity (TFP) are average annual growth rates. Capital deepening, intermediate deepening, and labor quality are average annual contributions (share-weighted growth rates). 


\begin{tabular}{|c|c|c|c|c|}
\hline Industry name & $1977-2000$ & $1977-90$ & $1990-95$ & $1995-2000$ \\
\hline Agriculture & 1.90 & 2.29 & 0.83 & 1.94 \\
\hline Non-energy mining & 0.82 & 0.83 & 1.16 & 0.46 \\
\hline Coal mining & 2.77 & 2.22 & 3.39 & 3.57 \\
\hline Oil and gas mining & -1.10 & -3.03 & 1.84 & 0.97 \\
\hline Construction & -1.08 & -1.06 & -1.27 & -0.95 \\
\hline Lumber, wood, furniture & 0.31 & 0.76 & -1.42 & 0.87 \\
\hline Stone, clay, glass & 0.44 & 0.31 & 0.32 & 0.87 \\
\hline Primary metal & 0.87 & 0.32 & 0.67 & 2.51 \\
\hline Fabricated metal & 0.45 & -0.29 & 1.16 & 1.64 \\
\hline Machinery, excl. computers & -0.52 & -1.20 & 0.49 & 0.23 \\
\hline Computers and office equipment & 12.87 & 11.77 & 11.87 & 16.75 \\
\hline Other electrical machinery & 0.84 & 0.46 & 1.71 & 0.93 \\
\hline Communications equipment & 1.70 & 1.91 & 3.23 & -0.38 \\
\hline Electronic components & 9.67 & 6.11 & 10.58 & 18.00 \\
\hline Motor vehicles & -0.07 & -0.28 & -0.24 & 0.64 \\
\hline Other transportation equipment & 0.40 & 0.29 & 0.17 & 0.94 \\
\hline Instruments and miscellaneous $\mathrm{mfg}$. & 0.35 & 0.88 & -0.45 & -0.25 \\
\hline Food and tobacco & 0.43 & 0.51 & 0.63 & 0.02 \\
\hline Textiles, apparel, leather & 1.10 & 0.80 & 0.83 & 2.14 \\
\hline Paper & 0.21 & -0.13 & -0.55 & 1.83 \\
\hline Printing and publishing & -0.53 & -0.73 & -1.09 & 0.56 \\
\hline Chemicals & -0.09 & -0.27 & -0.20 & 0.49 \\
\hline Petroleum refining & -0.49 & -0.07 & 1.68 & -3.72 \\
\hline Rubber and plastic & 1.29 & 1.24 & 1.20 & 1.51 \\
\hline Transportation & 0.15 & 0.18 & 0.46 & -0.21 \\
\hline Communications & 0.09 & 0.49 & 0.36 & -1.20 \\
\hline Electricity & 0.34 & -0.67 & 0.97 & 2.33 \\
\hline Gas & -0.90 & -0.88 & -2.19 & 0.34 \\
\hline Wholesale trade & 1.09 & 1.50 & 1.03 & 0.08 \\
\hline Retail and eating & 0.09 & -0.30 & -0.09 & 1.31 \\
\hline Finance & 0.61 & 0.23 & 1.26 & 0.96 \\
\hline Insurance & -1.71 & -2.14 & -0.93 & -1.38 \\
\hline Real estate (rental) & 0.21 & 0.14 & 0.93 & -0.35 \\
\hline Computer services & -0.03 & 0.39 & 1.62 & -2.79 \\
\hline Business svc., excl. computer & -0.39 & -0.58 & 0.64 & -0.92 \\
\hline Health, private & -1.50 & -1.68 & -1.60 & -0.93 \\
\hline Legal & -1.11 & -1.54 & -0.65 & -0.45 \\
\hline Education, private & -0.87 & -0.31 & -1.66 & -1.55 \\
\hline Professional and social svcs. & -0.26 & 0.35 & -0.93 & -1.20 \\
\hline Other services & -0.01 & -0.05 & -0.44 & 0.51 \\
\hline Government enterprises & 0.01 & -0.40 & -0.37 & 1.48 \\
\hline Household & 0.00 & 0.00 & 0.00 & 0.00 \\
\hline Government, excl. education & 0.00 & 0.00 & 0.00 & 0.00 \\
\hline Government education & 0.00 & 0.00 & 0.00 & 0.00 \\
\hline
\end{tabular}

Note: All figures are average annual growth rates. 
rates. Total factor productivity growth in Electronic Components accelerates steadily throughout the period 1977-2000, but the industry emerges as the leader in productivity growth only after 1995. Agriculture ranks third before 1990, and Coal Mining ranks third after 1990; both industries are far behind the two productivity leaders. Communications Equipment ranks fourth from 1990 to 1995, while Primary Metal ranks fourth after 1995.

The evolving patterns of TFP growth at the industry level are inconsistent with an explanation of negative productivity growth rates that relies solely on persistent errors of measurement. Rather, negative productivity growth rates appear to be a pervasive feature of industry performance in the U.S. economy across industries and over time. Only fourteen of the forty-one industries with nonzero productivity growth have positive productivity growth rates throughout the period 1977-2000, while five industries have negative productivity growth rates throughout the period. The remaining industries have both positive and negative growth rates of productivity; this clearly requires an explanation beyond persistent errors of measurement.

Labor productivity growth rates by industry and by subperiod are given in table 11.19. We see the same steady acceleration in labor productivity growth as in the growth of TFP in Computers and Electronic Components. Coal Mining outstrips Communications Equipment before 1990, and Computer Services is ranked fourth from 1990 to 1995 but drops below Coal Mining after 1995. Labor productivity growth also accelerates steadily in Communications Equipment but declines after 1995 in Computer Services. Construction is the only industry that exhibits a decline in labor productivity growth for all three subperiods.

\subsection{Aggregation over Industries}

To examine the U.S. economy as a whole, we next aggregate across industries. Jorgenson, Gollop, and Fraumeni (1987, chap. 2) show that the existence of an aggregate production function requires the very stringent assumption that value-added functions across industries are identical up to a scalar multiple. Here we employ an aggregate production possibility frontier introduced by Jorgenson (1995a) and used by Jorgenson and Stiroh (2000) and Jorgenson (2001). This methodology suppresses the industry dimension for inputs and assumes each input has the same marginal product in all industries, but relaxes the assumptions about value-added functions needed for the aggregate production function. We compare these to a third accounting approach for direct aggregation over industries.

\subsubsection{Aggregation}

We define the production possibility frontier as the efficient combination of outputs and inputs for the economy as a whole. Value added, $V$, consists 
Table 11.19 Growth of industry labor productivity, by subperiod

\begin{tabular}{|c|c|c|c|c|}
\hline Industry name & $1977-2000$ & $1977-90$ & $1990-95$ & 1995-2000 \\
\hline Agriculture & 3.02 & 3.39 & 1.83 & 3.23 \\
\hline Non-energy mining & 2.70 & 2.49 & 2.69 & 3.26 \\
\hline Coal mining & 6.68 & 6.55 & 6.20 & 7.49 \\
\hline Oil and gas mining & 0.38 & -1.39 & 2.64 & 2.72 \\
\hline Construction & -1.02 & -1.36 & -1.04 & -0.14 \\
\hline Lumber, wood, furniture & 1.17 & 1.19 & 0.38 & 1.92 \\
\hline Stone, clay, glass & 1.82 & 1.11 & 1.28 & 4.18 \\
\hline Primary metal & 2.36 & 1.63 & 3.42 & 3.20 \\
\hline Fabricated metal & 1.91 & 0.78 & 2.45 & 4.31 \\
\hline Machinery, excl. computers & 1.69 & 0.46 & 3.13 & 3.43 \\
\hline Computers and office equipment & 22.62 & 18.39 & 25.14 & 31.10 \\
\hline Other electrical machinery & 3.30 & 2.34 & 4.92 & 4.17 \\
\hline Communications equipment & 7.76 & 4.83 & 9.33 & 13.82 \\
\hline Electronic components & 15.98 & 9.81 & 22.45 & 25.57 \\
\hline Motor vehicles & 2.02 & 0.74 & 2.38 & 5.01 \\
\hline Other transportation equipment & 2.48 & 1.72 & 1.47 & 5.49 \\
\hline Instruments and miscellaneous $\mathrm{mfg}$. & 3.16 & 2.77 & 3.25 & 4.10 \\
\hline Food and tobacco & 1.81 & 1.99 & 1.67 & 1.50 \\
\hline Textiles, apparel, leather & 3.12 & 2.08 & 3.92 & 5.05 \\
\hline Paper & 1.76 & 1.70 & 1.74 & 1.94 \\
\hline Printing and publishing & 0.55 & 0.27 & -0.25 & 2.08 \\
\hline Chemicals & 1.47 & 0.87 & 2.22 & 2.28 \\
\hline Petroleum refining & 2.28 & 1.58 & 2.27 & 4.12 \\
\hline Rubber and plastic & 2.18 & 1.52 & 3.40 & 2.70 \\
\hline Transportation & 0.57 & 0.70 & 0.30 & 0.50 \\
\hline Communications & 2.92 & 3.18 & 3.63 & 1.54 \\
\hline Electricity & 2.18 & 0.59 & 3.27 & 5.22 \\
\hline Gas & -0.64 & -1.83 & -1.06 & 2.85 \\
\hline Wholesale trade & 2.81 & 2.62 & 3.33 & 2.78 \\
\hline Retail and eating & 1.10 & 0.67 & 0.73 & 2.59 \\
\hline Finance & 5.02 & 4.29 & 5.31 & 6.62 \\
\hline Insurance & 0.47 & 0.75 & 0.31 & -0.10 \\
\hline Real estate (rental) & 0.46 & 0.07 & 1.47 & 0.45 \\
\hline Computer services & 2.83 & 2.38 & 6.38 & 0.47 \\
\hline Business svc., excl. computer & -0.99 & -2.50 & 0.36 & 1.60 \\
\hline Health, private & -0.48 & -0.73 & -0.86 & 0.57 \\
\hline Legal & -1.84 & -3.31 & -0.72 & 0.87 \\
\hline Education, private & -0.38 & 0.28 & -1.69 & -0.78 \\
\hline Professional and social svcs. & 0.99 & 1.31 & -0.13 & 1.27 \\
\hline Other services & 0.67 & -0.38 & 1.90 & 2.20 \\
\hline Government enterprises & 1.52 & 0.74 & 1.48 & 3.58 \\
\hline Household & 3.69 & 3.59 & 2.76 & 4.85 \\
\hline Government, excl. education & 1.40 & 1.48 & 1.50 & 1.11 \\
\hline Government education & 0.25 & 0.20 & 0.38 & 0.24 \\
\hline
\end{tabular}

Note: All figures are average annual growth rates. 
of value added from all $J$ industries and is produced from primary inputs and technology as

$$
V\left(V_{1}, \ldots V_{J}\right)=f(K, L, T),
$$

where $V, K$, and $L$ are aggregate value added, capital services, and labor input, respectively.

The production possibility frontier does not impose the assumption of perfect substitution of value added between industries as required for existence of an aggregate production function. We define value added as a Tornqvist index over industry value added:

$$
\Delta \ln V=\sum_{j} \bar{w}_{j} \Delta \ln V_{j},
$$

where $\bar{w}_{j}$ is the two-period average share of industry value added in aggregate value added and $V_{j}$ is from equation (4).

There are many types of capital, $K_{k}$ (e.g., computers and tractors), and labor inputs, $L_{l}$ (e.g., high school-educated men and college-educated women), and market equilibrium requires that each input earns the same return in all industries. This assumption allows us to sum each input across industries to obtain aggregate capital services and labor input:

$$
\begin{aligned}
K_{k} & =\sum_{j} K_{k, j} \\
L_{l} & =\sum_{j} L_{l, j},
\end{aligned}
$$

where the $k$ subscript indexes the type of capital and $l$ indexes the type of labor.

Aggregate capital services and labor input are defined as Tornqvist indexes of all types of capital and labor, respectively:

$$
\begin{aligned}
& \Delta \ln K=\sum_{k} \bar{w}_{k} \Delta \ln K_{k} \\
& \Delta \ln L=\sum_{l} \bar{w}_{l} \Delta \ln L_{l},
\end{aligned}
$$

where the weights are the two-period average share of each type of capital or labor input in total capital or labor input. $P_{K}$ and $P_{L}$ are the corresponding price indexes for capital and labor, respectively.

We then define TFP growth as

$$
v_{T} \equiv \Delta \ln V-\bar{v}_{K} \Delta \ln K-\bar{v}_{L} \Delta \ln L,
$$

where the shares are the two-period average share of each input in aggregate value added.

As above, we can estimate the sources of aggregate labor productivity (value added per hour worked) as: 


$$
\Delta \ln v \equiv \bar{v}_{K} \Delta \ln k+\bar{v}_{L} \Delta \ln L Q+v_{T},
$$

where the definition of the determinants is the same as for industries, except there is no intermediate component.

An alternative approach developed by Jorgenson, Gollop, and Fraumeni (1987, chap. 2) is aggregation over industries, which provides estimates of aggregate TFP growth but also maintains the industry accounts as the basic building blocks. This avoids the assumption of mobility of inputs across industries and allows a decomposition of aggregate productivity growth to the industry-level sources. ${ }^{27}$ We begin with the definition of TFP growth from the production possibility frontier in equation (38) and industry TFP growth in equation (32). Multiply industry productivity growth (equation 33 ) by the industry share of aggregate value-added $\left(\bar{w}_{j}\right)$, divide through by the industry share of value added in output $\left(\bar{v}_{V, j}\right)$, and sum across all industries. This gives

$$
\sum_{j} \frac{\bar{w}_{j}}{\bar{v}_{V, j}} v_{T, j}=\sum_{j} \bar{w}_{j} \Delta \ln V_{j}-\sum_{j} \bar{w}_{j} \frac{\bar{v}_{K, j}}{\bar{v}_{V, j}} \Delta \ln K_{j}-\sum_{j} \bar{w}_{j} \frac{\bar{v}_{L, j}}{\bar{v}_{V, j}} d \ln L_{j} .
$$

Subtracting equation (40) from equation (38) yields the following decomposition of productivity growth from the aggregate production function:

$$
\begin{aligned}
v_{T}= & \left(\sum_{j} \frac{\bar{w}_{j}}{\bar{v}_{V, j}} v_{T, j}\right)+\left(\sum_{j} \bar{w}_{j} \frac{\bar{v}_{K, j}}{\bar{v}_{V, j}} \Delta \ln K_{j}-\bar{v}_{K} \Delta \ln K\right) \\
& +\left(\sum_{j} \bar{w}_{j} \frac{\bar{v}_{L, j}}{\bar{v}_{V, j}} \Delta \ln L_{j}-\bar{v}_{L} \Delta \ln L\right) \\
v_{T}= & \sum_{j} \frac{\bar{w}_{j}}{\bar{v}_{V, j}} v_{T, j}+\operatorname{REALL}_{K}+\operatorname{REALL}_{L}
\end{aligned}
$$

The first set of parentheses in equation (41) is the sum of "Domarweighted" industry rates of TFP growth, the second set is the reallocation of capital across industries $\left(\mathrm{REALL}_{K}\right)$, and the third is the reallocation of labor across industries $\left(\mathrm{REALL}_{L}\right)$. Productivity growth from the aggregate production possibility frontier exceeds Domar-weighted industry productivity when the reallocation terms are positive. This happens, for example, when the industries with higher prices of capital inputs have higher growth rates of capital input or when industries with the higher prices of labor inputs have higher growth rates of labor input. ${ }^{28}$

27. Note that Domar (1961) did assume mobility across industries.

28. Note that if we used capital stocks rather than capital services, there would be no RE$\mathrm{ALL}_{K}$ term because a given asset has the same price across all industries by construction. This implies that simple sums and translog indexes across industries are identical. Service prices for each asset, however, do differ across industries due to differences in rates of returns and taxes, so the term REALL R $_{K}$ is nonzero. 
A third alternative aggregation methodology, employed by Jorgenson, Gollop, and Fraumeni (1987, chap. 9), is based on an aggregate production function. Here, the price of a unit of value added must be the same in all industries in order to reduce the production possibility frontier to an aggregate production function. Under this assumption, value added from the aggregate production function, $V_{P F}$, is defined as a simple sum across industries:

$$
V_{P F}=\sum_{j} V_{j} \text {. }
$$

We define the difference in the growth rates of value added from the production possibility frontier in equation (34) and the aggregate production function in equation (42) as the reallocation of value added. This difference reveals the error in aggregation that results from assuming the existence of an aggregation production function and equal value-added prices. These results are presented in table 11.2 and were discussed in section 11.1.

An important feature of our methodology is that we are able to identify the contributions of individual industries to aggregate economic growth. This includes both the direct contribution to value added and the flows of goods and services among industries as intermediate inputs in the interindustry transactions tables. Triplett (1996), for example, has quantified the role of semiconductors as an input into the computer industry. Under plausible assumptions, falling semiconductor prices account for essentially all of the price decline in computers. Building on this observation, Oliner and Sichel (2000) constructed a model of the U.S. economy with three industries - computers, semiconductors, and all other products. The framework for aggregation over industries originated by Jorgenson, Gollop, and Fraumeni (1987, chap. 9) extends the same principles to all products and all industries.

The ingenious weighting scheme in equation (40), originated by Domar (1961), plays a key role in our framework for aggregation over industries. In this scheme the growth rate of each industry's output is weighted by the ratio of two proportions. The first is the proportion of each industry's value added in aggregate value added. The second is the proportion of value added in the industry's output. The ratio of these two proportions - the socalled Domar weight - captures both the relative importance of the industry in value added for the economy as a whole and the relative importance of value added in the industry's output. Note that the sum of the Domar weights exceeds unity.

\subsubsection{Aggregation Results}

Table 11.20 gives industry contributions to aggregate value added and TFP growth. Figure 11.1 arrays the industry contributions to value added in order of relative importance. We have weighted the growth rates of value added by industry from table 11.4 by each industry's share of value added 


\begin{tabular}{|c|c|c|c|c|c|c|}
\hline \multirow[b]{2}{*}{ Industry name } & \multicolumn{3}{|c|}{ Value added } & \multicolumn{3}{|c|}{ Productivity } \\
\hline & $\begin{array}{c}\text { Value } \\
\text { added } \\
\text { Weight }\end{array}$ & Growth & $\begin{array}{c}\text { Contribution } \\
\text { to aggregate } \\
\text { Value added }\end{array}$ & $\begin{array}{l}\text { Domar } \\
\text { weight }\end{array}$ & Growth & $\begin{array}{c}\text { Contribution } \\
\text { to aggregate } \\
\text { TFP }\end{array}$ \\
\hline Agriculture & 0.019 & 4.74 & 0.09 & 0.045 & 1.90 & 0.09 \\
\hline Non-energy mining & 0.002 & 1.89 & 0.00 & 0.004 & 0.82 & 0.00 \\
\hline Coal mining & 0.003 & 2.88 & 0.01 & 0.005 & 2.77 & 0.01 \\
\hline Oil and gas mining & 0.016 & 0.12 & -0.03 & 0.030 & -1.10 & -0.10 \\
\hline Construction & 0.046 & 0.40 & 0.01 & 0.103 & -1.08 & -0.12 \\
\hline Lumber, wood, furniture & 0.008 & 2.21 & 0.02 & 0.021 & 0.31 & 0.01 \\
\hline Stone, clay, glass & 0.005 & 1.55 & 0.01 & 0.011 & 0.44 & 0.00 \\
\hline Primary metal & 0.008 & 1.61 & 0.00 & 0.027 & 0.87 & 0.01 \\
\hline Fabricated metal & 0.013 & 1.87 & 0.02 & 0.029 & 0.45 & 0.01 \\
\hline Machinery, excl. computers & 0.016 & 0.33 & -0.01 & 0.034 & -0.52 & -0.03 \\
\hline \multicolumn{7}{|l|}{ Computers and office } \\
\hline equipment & 0.004 & 42.01 & 0.17 & 0.012 & 12.87 & 0.16 \\
\hline Other electrical machinery & 0.007 & 1.40 & 0.01 & 0.017 & 0.84 & 0.01 \\
\hline Communications equipment & 0.004 & 7.36 & 0.03 & 0.007 & 1.70 & 0.01 \\
\hline Electronic components & 0.005 & 25.44 & 0.15 & 0.011 & 9.67 & 0.12 \\
\hline Motor vehicles & 0.008 & 0.94 & 0.01 & 0.038 & -0.07 & 0.00 \\
\hline \multicolumn{7}{|l|}{ Other transportation } \\
\hline \multicolumn{7}{|l|}{ Instruments and } \\
\hline miscellaneous mfg. & 0.014 & 2.23 & 0.03 & 0.025 & 0.35 & 0.01 \\
\hline Food and tobacco & 0.019 & 2.51 & 0.05 & 0.066 & 0.43 & 0.03 \\
\hline Textiles, apparel, leather & 0.009 & 1.49 & 0.01 & 0.025 & 1.10 & 0.03 \\
\hline Paper & 0.008 & 1.80 & 0.01 & 0.020 & 0.21 & 0.00 \\
\hline Printing and publishing & 0.013 & 1.73 & 0.02 & 0.024 & -0.53 & -0.01 \\
\hline Chemicals & 0.019 & 1.44 & 0.02 & 0.047 & -0.09 & -0.01 \\
\hline Petroleum refining & 0.004 & 1.26 & -0.01 & 0.031 & -0.49 & -0.01 \\
\hline Rubber and plastic & 0.007 & 5.23 & 0.04 & 0.016 & 1.29 & 0.02 \\
\hline Transportation & 0.029 & 2.77 & 0.08 & 0.057 & 0.15 & 0.01 \\
\hline Communications & 0.020 & 4.47 & 0.09 & 0.036 & 0.09 & 0.00 \\
\hline Electricity & 0.017 & 2.01 & 0.03 & 0.028 & 0.34 & 0.01 \\
\hline Gas & 0.004 & -4.40 & -0.02 & 0.018 & -0.90 & -0.03 \\
\hline Wholesale trade & 0.051 & 5.35 & 0.28 & 0.079 & 1.09 & 0.09 \\
\hline Retail and eating & 0.064 & 2.48 & 0.16 & 0.110 & 0.09 & 0.01 \\
\hline Finance & 0.032 & 7.74 & 0.24 & 0.054 & 0.61 & 0.03 \\
\hline Insurance & 0.015 & 0.50 & 0.01 & 0.032 & -1.71 & -0.05 \\
\hline Real estate (rental) & 0.057 & 2.71 & 0.15 & 0.076 & 0.21 & 0.01 \\
\hline Computer services & 0.008 & 12.00 & 0.09 & 0.013 & -0.03 & -0.01 \\
\hline \multicolumn{7}{|l|}{ Business svc., excl. } \\
\hline computer & 0.022 & 6.30 & 0.14 & 0.030 & -0.39 & -0.01 \\
\hline Health, private & 0.045 & 2.47 & 0.10 & 0.067 & -1.50 & -0.10 \\
\hline Legal & 0.010 & 2.61 & 0.02 & 0.014 & -1.11 & -0.01 \\
\hline Education, private & 0.006 & 2.23 & 0.01 & 0.011 & -0.87 & -0.01 \\
\hline \multicolumn{7}{|l|}{ Professional and social } \\
\hline sves. & 0.044 & 4.42 & 0.19 & 0.067 & -0.26 & -0.03 \\
\hline Other services & 0.032 & 3.13 & 0.10 & 0.058 & -0.01 & 0.00 \\
\hline
\end{tabular}


Table 11.20 (continued)

\begin{tabular}{|c|c|c|c|c|c|c|}
\hline \multirow[b]{2}{*}{ Industry name } & \multicolumn{3}{|c|}{ Value added } & \multicolumn{3}{|c|}{ Productivity } \\
\hline & $\begin{array}{c}\text { Value } \\
\text { added } \\
\text { Weight }\end{array}$ & Growth & $\begin{array}{l}\text { Contribution } \\
\text { to aggregate } \\
\text { Value added }\end{array}$ & $\begin{array}{l}\text { Domar } \\
\text { weight }\end{array}$ & Growth & $\begin{array}{c}\text { Contribution } \\
\text { to aggregate } \\
\text { TFP }\end{array}$ \\
\hline Government enterprises & 0.015 & 2.13 & 0.03 & 0.023 & 0.01 & 0.00 \\
\hline Household & 0.138 & 3.69 & 0.51 & 0.138 & 0.00 & 0.00 \\
\hline $\begin{array}{l}\text { Government, excl. } \\
\text { education }\end{array}$ & $\begin{array}{l}0.084 \\
0.038\end{array}$ & $\begin{array}{l}1.38 \\
2.13\end{array}$ & $\begin{array}{l}0.12 \\
0.08\end{array}$ & $\begin{array}{l}0.084 \\
0.038\end{array}$ & $\begin{array}{l}0.00 \\
0.00\end{array}$ & $\begin{array}{l}0.00 \\
0.00\end{array}$ \\
\hline $\begin{array}{l}\text { Government education } \\
\text { Sum }\end{array}$ & 1.00 & 2.15 & 3.08 & 1.70 & & 0.16 \\
\hline
\end{tabular}

Notes: All figures are annual averages. Value-added weights are industry value-added as a share of aggregate value added. Domar weights are industry output as a share of aggregate value added. A contribution is a share-weighted growth rate.

for the U.S. economy as a whole. Note that these value-added shares sum to one. Three IT-producing industries-Computers, Electronic Components, and Computer Services - have the highest rates of growth of value added. However, the contributions of these industries to value added for the economy as a whole are relatively modest, reflecting the small relative size of these industries.

The Household sector is the most important contributor to the growth of aggregate value added. While the growth rate of value added in this industry is only a little above the economywide growth rate, the Household sector accounts for a whopping 13.7 percent of aggregate value added, giving its growth rate a very large weight. By comparison, the value-added weight for Computers is 0.4 percent, while that of Electronic Components is 0.5 percent. Wholesale Trade, Finance, and Professional and Social Services - all industries with very sizable weights - round out the list of leading contributors to growth of aggregate value added.

Figure 11.2 ranks industries by their contributions to aggregate TFP growth. This picture contrasts sharply with that for value added. Table 11.18 has shown that Computers and Electronic Components have the highest rates of productivity growth at the industry level. Weighting these growth rates by the Domar scheme described above, we find that the contributions of these industries, 0.16 and 0.12 , respectively, more than exhaust the aggregate rate of TFP growth of 0.16 . One possible conclusion is that all productivity growth originates in these two IT-producing industries. However, this conclusion would be highly misleading, as the sum of the contributions of the following two industries-Agriculture and Wholesale Trade -0.09 for both industries, also exhausts TFP growth for the economy as a whole.

The resolution of the apparent paradox is that aggregate TFP growth is the sum of positive and negative contributions from forty-one different in- 
Household

Finance

Professional and Social Services

Computers and Office Equipment

Retail and Eating

Real Estate (rental)

Electronic Components

Business Service excluding Computer

Government excluding Education

Health, private

Other Services

Agriculture

Communications

Computer Services

Government Education

Transportation

Food and Tobacco

Rubber and Plastic

Electricity

Government Enterprises

Instruments and Misc. Manufacturing

Communications Equipment

Chemicals

Printing and Publishing

Legal

Lumber, Wood, Furniture

Fabricated Metal

Other Transportation Equipment

Paper

Education, private

Construction

Textiles, Apparel, Leather

Other Electrical Machinery

Insurance

Motor Vehicles

Stone, Clay, Glass

Coal Mining

Primary Meta

Non Energy Mining

Machinery excluding Computers

Petroleum Refining

Oil and Gas Mining

Gas

$-0.1$

0

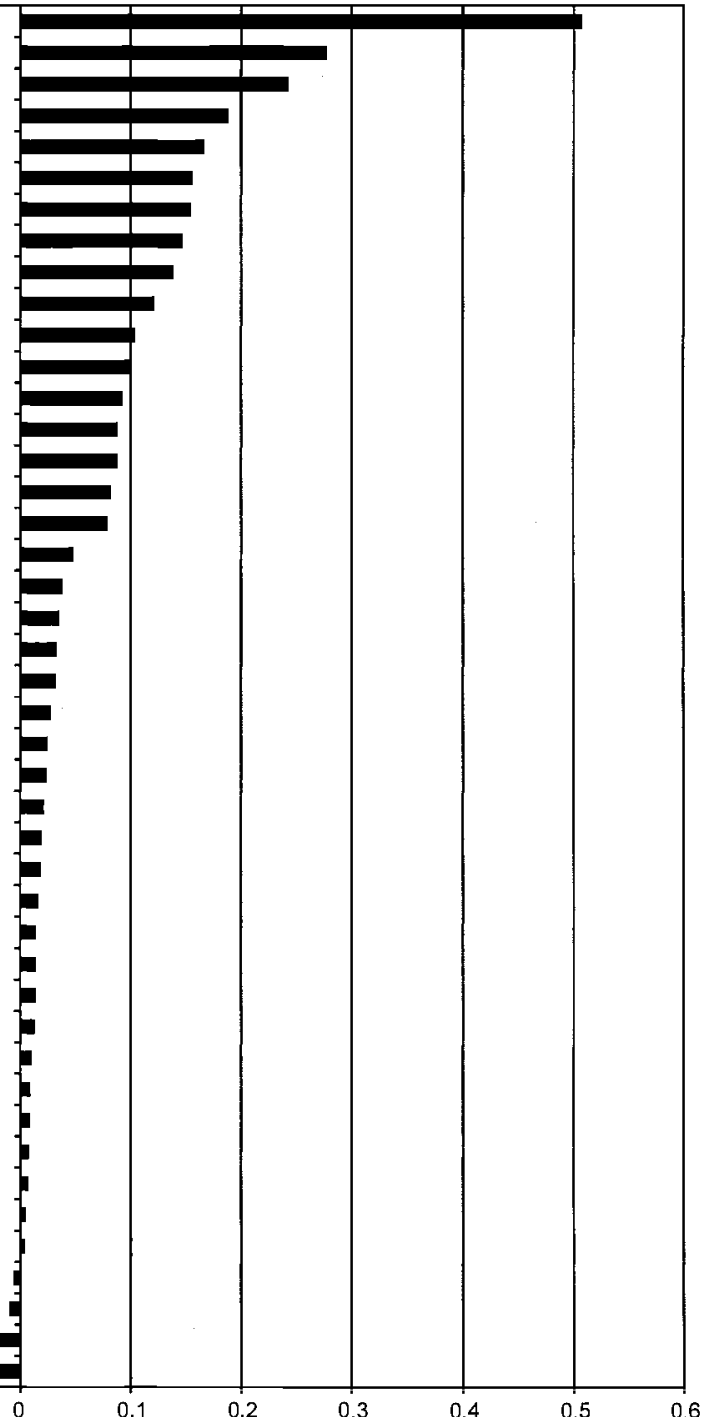

Fig. 11.1 Industry contributions to value-added growth, 1977-2000

dustries. Offsetting the large positive contributions of the four leading sectors we have identified are large negative contributions by Insurance, Oil and Gas Mining, Health Services, and Construction. The correct inference from the data on TFP growth given in table 11.20 is that industry-level TFP growth can be either negative or positive and aggregate TFP growth must give appropriate weight to both.

Domar-weighted TFP growth rates given in table 11.2 above are sums of 


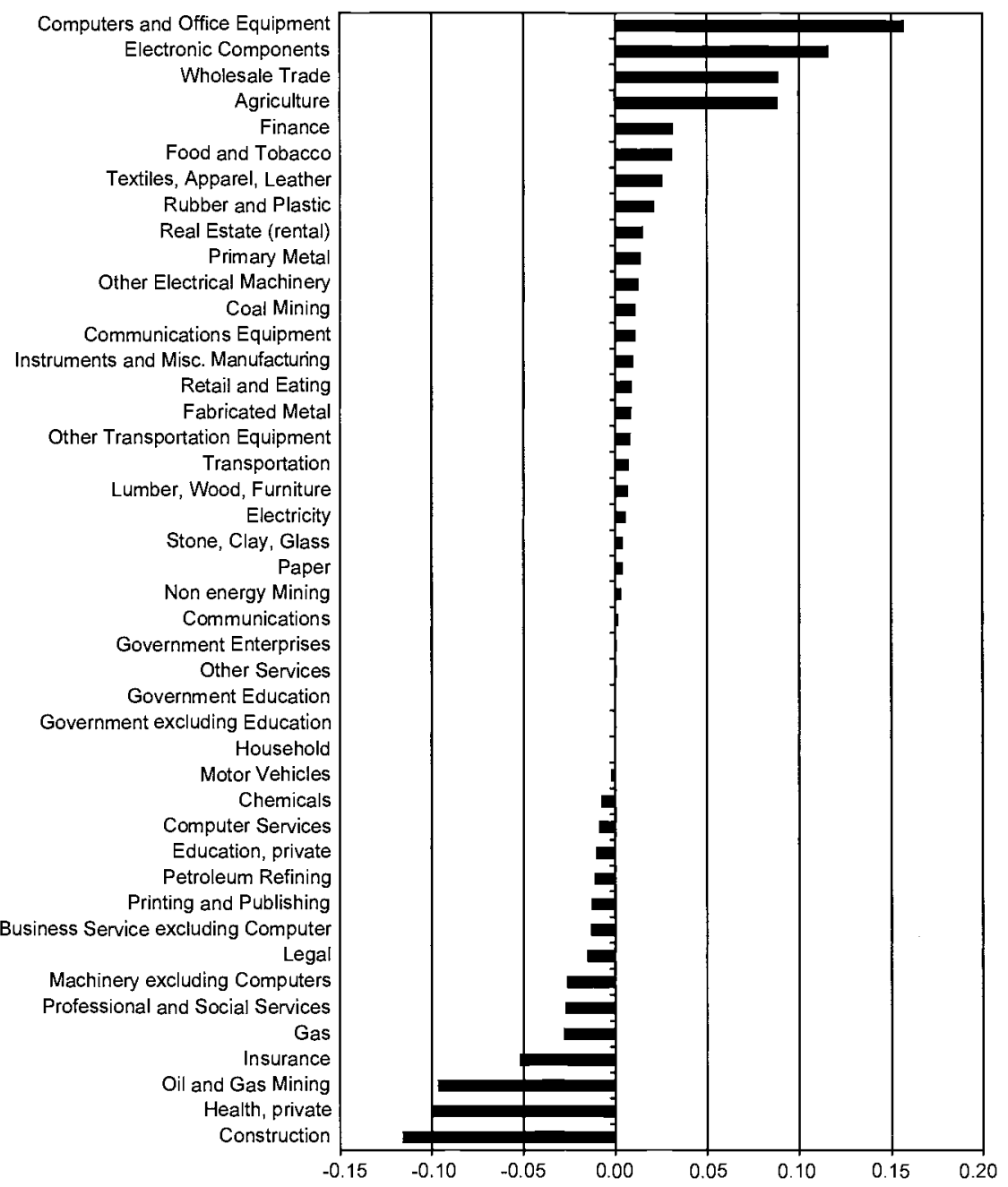

Fig. 11.2 Industry contributions to total factor productivity, 1977-2000

Note: Industries sorted by productivity contribution.

contributions from table 11.20. These weights capture the impact of TFP growth in the industry where it takes place, as well as the industries that purchase the output of this industry as intermediate inputs and as investments. The IT component is the sum over the four IT-producing industries-Computers, Communications Equipment, Electronic Components, and Computer Services. This rises steadily over the period 1977-2000, reflecting accelerations in productivity growth for Computers and Electronic Components. The contributions of Communications Equipment and 
Computer Services are comparable in magnitude and opposite in sign, so that these relatively small contributions are mutually offsetting.

The non-IT component of the Domar-weighted growth rates given in table 11.2 is the sum over the thirty-seven non-IT industries. This component also accelerates over the period 1977-2000 but is negative before 1990, offsetting the positive contribution to aggregate productivity growth by the IT-producing industries. The non-IT component is positive after 1990 and contributes to the modest recovery of aggregate productivity growth from 1990 to 1995 and the acceleration after 1995.

Table 11.2 also gives a decomposition of TFP growth. This includes the Domar-weighted productivity growth rates for the IT and non-IT sectors, as well as reallocations of capital and labor input within these sectors. These reallocations are defined precisely in equation (41) and reflect differences in the cost of capital and wage rates among industries. For the period $1977-2000$ as a whole the reallocations are fairly modest in size, so that the TFP growth rate closely tracks the Domar-weighted sum of productivity growth rates at the industry level.

For the subperiod 1990-95 the reallocation of non-college-educated labor input among sectors is economically significant and makes a negative contribution to TFP growth, suggesting that non-college-educated labor input is moving to sectors with lower wage rates for a given set of characteristics - age, sex, and class of employment. This movement masks part of the recovery in productivity growth in both IT and non-IT industries that took place during 1990-95 and exaggerates the acceleration in productivity growth after 1995 . The Domar-weighted sum of industry productivity growth rates in table 11.2 is the most accurate indicator of this acceleration at the industry level.

Our final set of results focuses on the contributions of each industry to the resurgence of U.S. TFP growth after 1995. Figure 11.3 presents Domarweighted growth rates of TFP for each industry for 1977-95 and 19952000, ranked by the 1995-2000 contribution. The combined increases in two IT-producing industries, Electronic Components and Computers, account for most of the acceleration in productivity for the economy as a whole. However, it would be seriously misleading to attribute the entire aggregate increase to the two industries. The contributions of renewed productivity growth in Retail Trade and Eating and Oil and Gas Mining are comparable in magnitude to Electronic Components as a source of the resurgence of TFP growth.

There are many industries that reveal increases in TFP growth and others that show declines. Wholesale Trade, Petroleum Refining, Computer Services, and Professional and Social Services are industries that experienced substantial slowdowns in TFP growth, while aggregate TFP growth accelerated. We conclude that attribution of TFP growth to industries is highly arbitrary. It is far easier and much more important to allocate the 


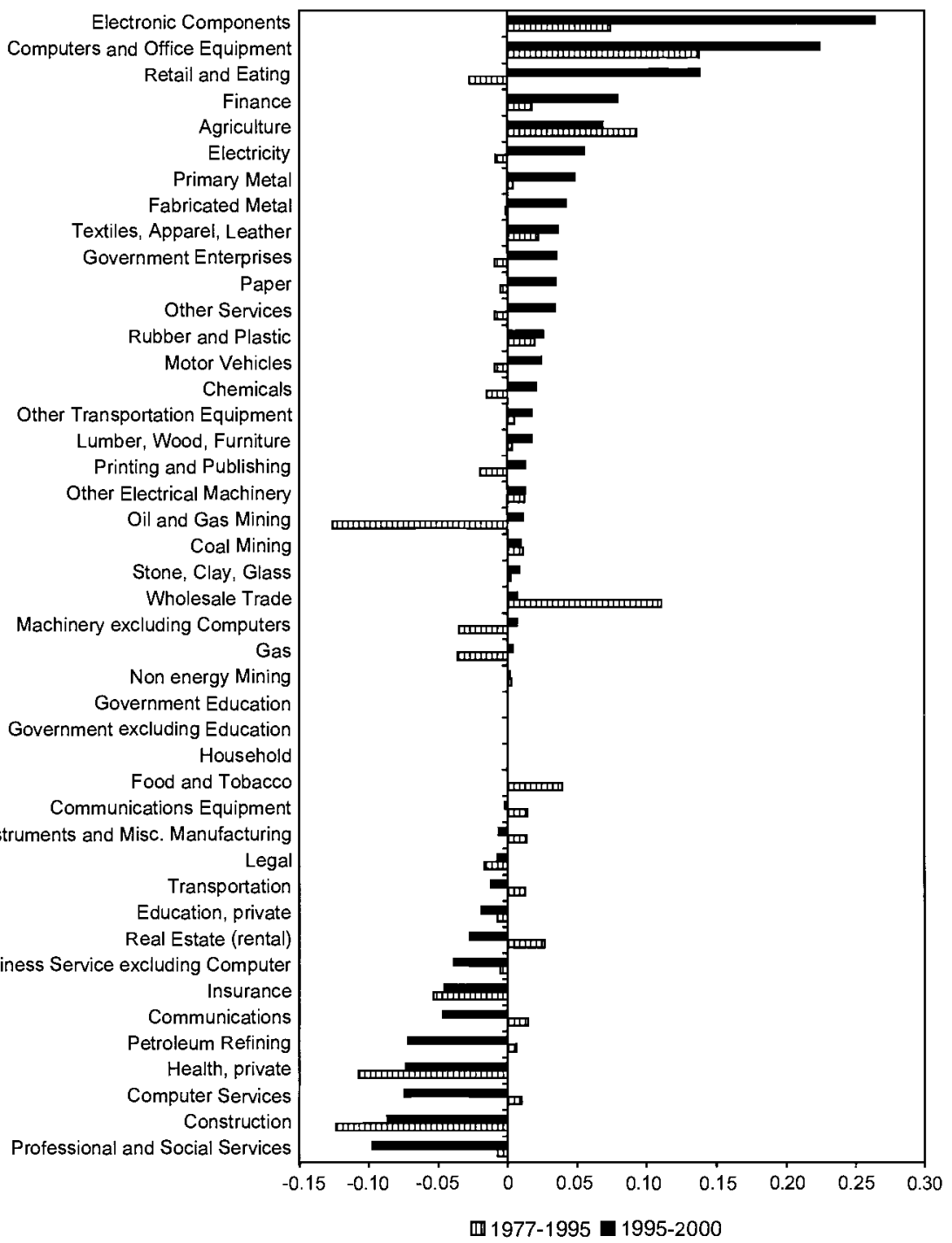

Fig. 11.3 Domar-weighted productivity contributions 1995-2000 versus 1977-95 Note: Industries sorted by $1995-2000$ productivity contribution.

contributions of capital and labor inputs to individual industries, as we have done above. This shows that the resurgence in economic growth is due largely to massive investments in IT capital input and college-educated labor input in a relatively small number of service industries, as well as Households and government sectors. 
Greenwood, Hercowitz, and Krusell (1997, 2000) and Hercowitz (1998) have attributed some 60 percent of postwar U.S. economic growth to investment-specific productivity growth. As evidence, they note that the relative price of equipment has fallen 3 percent per year. We have incorporated this effect by calculating growth rates of productivity for all industries. Investment goods are produced by specific industries and are priced as industry outputs. As a leading example, we have shown that declining prices of IT investment goods are the consequence of productivity growth in the IT-producing sectors.

\subsection{Conclusions}

We have completed our program of attributing U.S. economic growth to its sources at the industry level. For this purpose we have employed new conceptual tools and data, specifically industry-level models of production and the production possibility frontier for the U.S. economy as a whole. This makes it possible to incorporate data on output and intermediate input from a time series of interindustry transactions tables, identifies the impact of IT-producing industries, and facilitates the identification of the role of investments in IT equipment and higher education in U.S. economic growth. Finally, this approach embodies internationally recommended standard practices for productivity measurement, as presented by Schreyer (2001) in the OECD Productivity Manual.

Our first conclusion is that many of the concepts used in earlier industry-level growth accounting should be replaced. The aggregate production function heads this list. The data indicate that the production possibility frontier better captures the impact of information technology on both outputs and inputs at the industry level. This is especially apparent when detailed industry data reveal the large changes in relative prices between ITproducing and non-IT-producing industries. Similarly, capital stock as a measure of capital input and hours worked as a measure of labor input, both still commonly used in growth accounting, ignore important compositional changes and must be replaced by the measures of capital and labor input presented above.

Investments in information technology and higher education stand out as the most important sources of growth at both industry and economywide levels. While investments in IT take place within the sectors we have identified, investments in higher education are undertaken by future workers when they are enrolled in institutions of higher education, primarily colleges and universities. We have measured the growth of labor input from college-educated and non-college-educated workers, but not the massive investment that precedes it. We have measured investment and capital stock, as well as capital input, from IT and non-IT capital.

The growth of TFP is an important source of growth, but it is far less sig- 
nificant in economic terms than investments in information technology and higher education. Tracing this to its sources at the industry level is highly problematical, however, because industry-level TFP growth rates can be positive or negative and can alternate between the two. Nonetheless, a key force behind TFP growth at the aggregate level can be identified in the dramatic growth of productivity in the Computer and Electronic Component industries. This stands out in comparisons among industries, as well as through aggregation over industries.

Total factor productivity growth outside the IT-producing sectors also makes important contributions to fluctuations in aggregate TFP growth. This is especially apparent during the post-1995 growth resurgence, when a sharp recovery in Retail Trade and Oil and Gas Mining made a significant contribution to the revival of TFP growth. However, this revival plays a modest part in the surge in growth, relative to IT investment. The dramatic IT investment boom after 1995 culminates a steady rise in the importance of this investment over the period 1977-2000. Although investment in IT dominates investment in non-IT as a source of growth of capital input, non-IT investment is also important in the growth resurgence.

The growth of college-educated labor input dominates that of noncollege-educated labor input during the period of our study. This is concentrated in trade, finance, and service industries that also make large investments in IT. A possible explanation is that college-educated labor is complementary to IT capital, so that the decline in the price of IT drives up the demand for both IT capital and college-educated workers. An alternative explanation is that productivity growth is biased toward collegeeducated workers, making them relatively more productive than noncollege-educated workers.

Enormous uncertainties still surround the relationship between equity valuations and future growth prospects of the American economy. One theory attributes rising equity valuations since the growth resurgence that began in 1995 as the response of equity values to the accumulation of intangible assets, such as intellectual property and organizational capital. An alternative theory treats the high valuation of technology stocks as a bubble that burst, beginning in $2000 .{ }^{29}$ Similar uncertainties characterize investments in human capital by knowledge workers. The uncertainties are magnified by the great distance in time between these investments and the compensation for the labor services of knowledge workers.

The restructuring of the American economy in response to the progress of information technology has been massive and continuous. The structure of output is shifting toward the IT-producing industries, but even more substantially toward the IT-using industries. The capital deployed in the

29. Campbell and Shiller (1998) and Shiller (2000) discuss equity valuations and growth prospects. Brynjolfsson and Hitt (2000) and Hall (2001) evaluate unobservable components of investment on the basis of equity valuations. 
economy is moving rapidly toward IT equipment and software. Finally, the composition of the work force is evolving toward more college-educated workers as investments in higher education continue to rise. These structural changes create risks and rewards for investments in both IT and higher education that businesses and individuals must learn to manage.

Our final conclusion is that restructuring our official statistics to describe the ongoing structural changes more accurately is an important step in the management of the new risks that we face collectively. With the establishment of international standards for productivity measurement, the time is ripe for incorporation of industry and economywide production accounts into systems of national accounts, as proposed by Christensen and Jorgenson (1995), Jorgenson, Gollop, and Fraumeni (1987), and Jorgenson (2001). This requires integration of interindustry transactions tables, like those we have employed in measuring output and intermediate input, with accounts for gross product originating, like those we have used in allocating value added between capital and labor compensation. It also requires measures of flows of services from tangible assets and human capital, like those that provide the basis for our measures of capital and labor input.

Table 11A.1 Classification of civilian labor force

\begin{tabular}{lcl}
\hline & No. & \multicolumn{1}{c}{ Categories } \\
\hline Sex & 2 & Male; female \\
Class & 2 & $\begin{array}{l}\text { Employees; self-employed and unpaid } \\
\text { Age }\end{array}$ \\
$\begin{array}{lcl}\text { Education } \\
1980-92\end{array}$ & 6 & $\begin{array}{l}\text { 0-8 years grade school; 1-3 years high school; 4 years high school; 1-3 } \\
\text { years college; 4 years college; 5+ years college }\end{array}$ \\
$1992+$ & 6 & $\begin{array}{l}\text { 0-8 years grade school; grade 9-12 no diploma; high school graduate } \\
\text { some college no BA; bachelor's degree; more than BA degree } \\
\text { Industries listed in table 11.3 }\end{array}$ \\
Industry & 44 &
\end{tabular}

\section{References}

Baily, Martin N. 2002. The new economy: Post mortem or second wind. Journal of Economic Perspectives 16:3-22.

Baily, Martin N., and Robert J. Gordon. 1988. The productivity slowdown and explosion of computer power. Brookings Papers on Economic Activity, Issue no. 2:1-45.

Baily, Martin N., and Robert Z. Lawrence. 2001. Do we have a new e-conomy? American Economic Review, Papers and Proceedings 91:308-13. 
Basu, Susanto, and John G. Fernald. 1995. Are apparent productive spillovers a figment of specification error? Journal of Monetary Economics 36:165-88. 1997. Returns to scale in U.S. production: Estimates and implications. Journal of Political Economy 105:249-83.

Basu, Susanto, John G. Fernald, and Matthew D. Shapiro. 2001. Productivity growth in the 1990s: Technology, utilization, or adjustment? Carnegie-Rochester Conference Series on Public Policy 55:117-66.

Becker, Gary. 1985. Human capital, effort, and the sexual division of labor. Journal of Labor Economics 3:S33-S58.

Berndt, Ernst R., and Melvyn A. Fuss. 1986. Productivity measurement with adjustments for variations in capacity utilization and other forms of temporary equilibrium. Journal of Econometrics 33:7-29.

Blades, Derek. 2001. Measuring capital: A manual on the measurement of capital stocks, consumption of fixed capital, and capital services. Paris: Organization for Economic Cooperation and Development.

Bonds, Belinda, and Tim Aylor. 1998. Investment in new structures and equipment in 1992 by using industries. Survey of Current Business 78 (8): 26-51.

Brynjolfsson, Erik, and Lorin M. Hitt. 2000. Beyond computation: Information technology, organization transformation, and business practices. Journal of Economic Perspectives 14:23-48.

Bureau of Economic Analysis (BEA). 1997. Note on alternative measures of gross product by industry. Survey of Current Business 77 (11): 84-85.

1999. Fixed reproducible tangible wealth in the United States, 1925-94. Washington, DC: U.S. Department of Commerce.

Bureau of Labor Statistics (BLS). 1993. Labor composition and U.S. productivity growth, 1948-90. Bureau of Labor Statistics Bulletin no. 2426. Washington, DC: U.S. Department of Labor.

Campbell, John Y., and Robert J. Shiller. 1998. Valuation ratios and the long-run stock market outlook. Journal of Portfolio Management 24 (2): 11-26.

Christensen, Laurits R., and Dale W. Jorgenson. 1995. Measuring economic performance in the private sector. In Postwar U.S. economic growth, ed. Dale W. Jorgenson, 175-272. Cambridge: MIT Press.

Congressional Budget Office. 2002. The budget and economic outlook: Fiscal years 2003-2012. Washington, DC: Government Printing Office, January.

Council of Economic Advisors. 2002. Economic report of the president. Washington, DC: U.S. Government Printing Office, February.

Corrado, Carol, and Lawrence Slifman. 1999. Decomposition of productivity and unit costs. American Economic Review, Papers and Proceedings 89:328-32.

Domar, Evsey. 1961. On the measurement of technological change. Economic Journal 71:709-29.

Dulberger, Ellen R. 1993. Sources of decline in computer processors: Selected electronic components. In Price measurements and their uses, ed. Murray F. Foss, Marilyn Manser, and Allan H. Young, 103-24. Chicago: University of Chicago Press.

Federal Reserve Board. 1995. Balance sheets for the U.S. economy. Release C.9. Washington, DC: Federal Reserve Board, June.

1997. Flow of funds accounts of the United States. Release Z.1. Washington, DC: Federal Reserve Board.

Fraumeni, Barbara. 1997. The measurement of depreciation in the U.S. national income and product accounts. Survey of Current Business 77 (7): 7-23.

Gordon, Robert J. 2002. Technology and economic performance in the U.S. economy. NBER Working Paper no. 8771. Cambridge, MA: National Bureau of Economic Research, February. 
Greenwood, Jeremy, Zvi Hercowitz, and Per Krusell. 1997. Long-run implications of investment-specific technological change. American Economic Review 87:34263.

2000. The role of investment-specific technological change in the business cycle. European Economic Review 44:91-115.

Gullickson, William, and Michael J. Harper. 1999. Possible measurement bias in aggregate productivity growth. Monthly Labor Review 122 (2): 47-67.

Hall, Robert E. 1988. The relationship between price and marginal cost in U.S. industry. Journal of Political Economy 96:921-47.

2001. The stock market and capital accumulation. American Economic Review $91: 1185-1202$.

Hall, Robert E., and Dale W. Jorgenson. 1996. Tax policy and investment behavior. In Tax policy and the cost of capital, ed. Dale W. Jorgenson, 1-26. Cambridge: MIT Press.

Hercowitz, Zvi. 1998. The "embodiment" controversy: A review essay. Journal of Monetary Economics 41:217-24.

Herman, Shelby W. 2000a. Fixed assets and consumer durable goods. Survey of Current Business 80 (4): 17-30.

. 2000b. Fixed assets and consumer durable goods for 1925-99. Survey of Current Business 80 (9): 19-30.

Ho, Mun Sing, and Dale W. Jorgenson. 1999. The quality of the U.S. workforce, 1948-95. Harvard University, Department of Economics. Manuscript.

Ho, Mun Sing, and Kevin J. Stiroh. 2001. The embodiment controversy: You can't have two prices in a one-sector model. Federal Reserve Bank of New York. Manuscript.

Jaeger, David A. 1997. Reconciling the old and new Census Bureau education questions: Recommendations for researchers. Journal of Business and Economic Statistics 15:300-309.

Jorgenson, Dale W. 1995a. The embodiment hypothesis. In Postwar U.S. economic growth, 25-50. Cambridge: MIT Press.

1995b. Productivity and economic growth. In International comparisons of economic growth, 1-88. Cambridge: MIT Press.

1996. Capital theory and investment behavior. In Capital theory and investment behavior, 1-16. Cambridge: MIT Press.

2001. Information technology and the U.S. economy. American Economic Review 91:1-32.

Jorgenson, Dale W., Frank M. Gollop, and Barbara M. Fraumeni. 1987. Productivity and U.S. economic growth. Cambridge: Harvard University Press.

Jorgenson, Dale W., and Zvi Griliches. 1995. The explanation of productivity change. In Postwar U.S. economic growth, ed. Dale W. Jorgenson, 51-98. Cambridge: MIT Press.

Jorgenson, Dale W., Mun S. Ho, and Kevin J. Stiroh. 2002. Projecting productivity growth: Lessons from the U.S. growth resurgence. Federal Reserve Bank of Atlanta Economic Review 87 (3): 1-13.

Jorgenson, Dale W., and Kevin J. Stiroh. 2000. Raising the speed limit: U.S. economic growth in the information age. Brookings Papers on Economic Activity, Issue no. 1:125-211.

Jorgenson, Dale W., and Kun-Young Yun. 2001. Lifting the burden: Tax reform, the cost of capital, and U.S. economic growth. Cambridge: MIT Press.

Kroch, Eugene A., and Kriss Sjoblom. 1994. Schooling as human capital or a signal. Journal of Human Resources 29:156-80.

Lane, Richard N. 1999. Appraisal report "large aerospace firm" personal property, Los Angeles County, March 1, 1995. Revised February 1. 
Lum, Sherlene K. S., and Brian C. Moyer. 2000. Gross domestic product by industry for 1997-99. Survey of Current Business 80 (12): 24-35.

McKinsey Global Institute. 2001. U.S. productivity growth, 1995-2000: Understanding the contribution of information technology relative to other factors. Washington, DC: McKinsey Global Institute, October.

Oliner, Stephen D. 1993. Constant-quality price change, depreciation, and the retirement of mainframe computers. In Price measurements and their uses, ed. Murray F. Foss, Marilyn E. Manser, and Allan H. Young, 19-61. Chicago: University of Chicago Press.

1994. Measuring stocks of computer peripheral equipment: Theory and application. Washington, DC: Board of Governors of the Federal Reserve System, May.

Oliner, Stephen D., and Daniel E. Sichel. 2000. The resurgence of growth in the late 1990s: Is information technology the story? Journal of Economic Perspectives $14: 3-22$.

- 2002. Information technology and productivity: Where are we now and where are we going? Federal Reserve Bank of Atlanta Economic Review 87 (3): 15 44.

Schreyer, Paul. 2001. OECD productivity manual: A guide to the measurement of industry-level and aggregate productivity growth. Paris: Organization for Economic Cooperation and Development, March.

Shiller, Robert. 2000. Irrational exuberance. Princeton, NJ: Princeton University Press.

Solow, Robert M. 1960. Investment and technical progress. In Mathematical methods in the social sciences, 1959, ed. Kenneth J. Arrow, Samuel Karlin, and Patrick Suppes, 89-104. Stanford, CA: Stanford University Press.

Spence, A. Michael. 1973. Job market signaling. Quarterly Journal of Economics $87: 355-74$.

Stiroh, Kevin J. 2002. Information technology and the U.S. productivity revival: What do the industry data say? American Economic Review 92 (5): 1559-76.

Triplett, Jack E. 1996. High-tech industry productivity and hedonic price indices. In Industry productivity, international comparison, and measurement issues, 11942. Paris: Organization for Economic Cooperation and Development.

Unicon Research Corporation. 2002. CPS utilities. Santa Monica, CA: Unicon Research Corporation.

United Nations. 1993. System of national accounts 1993. New York: United Nations.

Whelan, Karl. 2002. Computers, obsolescence, and productivity. Review of Economics and Statistics 84:445-62.

\section{Comment Michael J. Harper}

This paper by Dale Jorgenson, Mun Ho, and Kevin Stiroh (hereafter JHS) is the latest in a thirty-six-year series of major empirical studies of U.S. eco-

The author is chief of the Division of Productivity Research and Program Development of the U.S. Bureau of Labor Statistics and a member of the executive committee of the Conference on Research in Income and Wealth. The views expressed here are those of the author and do not necessarily reflect the views of the Bureau of Labor Statistics or its staff. 
nomic growth conducted by Dale Jorgenson and various coauthors. It has its roots in Jorgenson's paper with Zvi Griliches (1967), in which most of the distinctive methodological features of this series of studies were introduced. While there are a few refinements in this paper, the methodology for measuring industry-level outputs and inputs is essentially the same as that used in the book by Jorgenson, Frank Gollop, and Barbara Fraumeni (1987; hereafter JGF). This framework has stood the test of time and remains the state of the art in accounting for economic growth. At the $\mathrm{Bu}-$ reau of Labor Statistics (BLS) we institutionalized many of the distinctive features of the input side of this framework in our "multifactor productivity measures" (BLS 1983), and our colleagues at the Bureau of Economic Analysis (summarized by Steve Landefeld and Robert Parker [1995]) have adopted its approach to measuring output with a chained superlative index number. This tradition continues to flourish. Within the past few years Australia and Canada have published productivity measures using this framework, and Great Britain is working on similar measures.

So the absence of major methodological innovation does not detract from the importance of this particular study. To the contrary, it is very important to look at newly emerging issues in the economy, like the high-tech revolution, through the lens of measurement methods that were established and understood a priori. It is fortunate indeed that Jorgenson continues to guide the tradition through his involvement in new empirical work. It is with admiration and respect for the continuity of an important tradition that people have labeled these studies the "Jorgenson Statistical Agency."

Why has this particular tradition maintained its momentum? It is because it devises a set of national accounts and productivity statistics that are built on neoclassical principles. By this I mean that the methodological choices flow from mathematical models of production and from assumptions of efficient economic behavior. These models drive the notion of capital "services" (as distinct from capital stock), the "Translog" aggregation technique, the "quality" adjustments to inputs and outputs, the treatment of intermediate inputs, and even the choice of the scope of the economy. I will comment on some of these major methodological features before offering a few thoughts on the results.

But first we should recall the state of statistics back around the 1960s. The Conference on Research in Income and Wealth had played a major role in shaping the U.S. National Income and Product Accounts (NIPAs) as celebrated in the fiftieth-anniversary volume edited by Berndt and Triplett (1990). The NIPAs were crafted to measure the "final" goods and services created by the economy. This was of course a key concept in the Keynesian model. Many of the current measurement programs of U.S. statistical agencies emerged during the 1940s, 1950s, and 1960s to support improved measurement of real final production. The strategy was to tabulate 
nominal market transactions, remove any that represented unfinished goods or services moving between stages of processing, and then express the result in real terms. These measures of real gross domestic product (GDP, although back then gross national product was emphasized) fast became the basis for macro models, models of inflation, and aggregate productivity statistics.

A problem was that many strong assumptions were being built very deeply into the structure of the statistical edifice. The literature of the 1950s, 1960s, and 1970s focused on these assumptions, and many methods emerged that reduced the degree of restrictiveness. The Jorgenson series of empirical papers has restructured and recalculated the aggregate measures using the more flexible methods.

In the 1950s, the premier shortcoming of national accounts was the lack of a capital measure. National accountants treated capital goods as a "final output," as Keynes had dictated, but neglected the very important role of capital as an input. Since it was recognized that capital goods were not ultimately consumed, national accountants developed "net national product" to measure economic growth net of depreciation. The removal of depreciation mirrored the removal of sales of unfinished goods. However, this treatment oversimplifies the dynamic role that capital plays in production and in economic growth. After several years of debate in the literature that probed the capital measurement issue, Solow (1957) proposed a model that treated capital as an input that contributed to production and to labor productivity. The weight for capital's contribution to labor productivity, capital's cost share, emerged from assuming competitive markets for inputs. The residual of capital's contribution to labor productivity growth is known as "total factor" or "multifactor" productivity.

Early on, there was resistance to the Solow model, with many authors pointing to internal inconsistencies in Solow's capital measure. The Jorgenson and Griliches (1967) article (hereafter JG) was the first major empirical study to resolve an important inconsistency concerning the aggregation of equipment and buildings. JG elaborated Solow's "production theory" to handle a situation where there are different types of capital by treating each input type as a separate category (each a separate variable in a production function). Capital inputs were viewed as flows of services that could be different for each type of capital. The prices of renting these services, rather than the prices of buying the capital goods, were identified by JG as the relevant prices for employing capital inputs in a given year's production. The property income earned by capital assets was the relevant compensation of capital inputs. This methodology eliminated the strong assumption involved when capital stocks (for example, stocks of trucks and stocks of buildings) were simply added together. This technique has been expanded here by JHS to elucidate the role of computers in the recent productivity growth surge. 
The JG article pushed the aggregate accounting frontier forward in two other important ways: different types of labor were treated as separate inputs, and a flexible index number formula was used for all aggregation. This "translog" production function, which was later estimated econometrically by Christensen, Jorgenson, and Lau (1973), was a very general specification that placed no a priori restrictions on the elasticities of substitution among inputs. The index number formula used by JG was related to the translog. It was a decade later that Diewert (1976) showed that many index number formulas correspond to particular specifications of production functions and production frontiers. Diewert pointed out that the translog index corresponded to an index number formula proposed earlier by Tornqvist. The Tornqvist and the Fisher Ideal index formulas were dubbed "superlative" by Diewert, meaning that they could be derived from flexible functional specifications.

The JG empirical deployment of flexible index number formulas was decades ahead of its time. In 1967, real GDP in the U.S. national accounts was constructed by adding up "constant base-period dollars." Constant dollars were simple and provided a good approximation to the superlative formulas, as long as relative prices remained stable. After sixteen years and some intensive research, the BLS (1983) introduced business-sector multifactor productivity measures that used superlative formulas to aggregate inputs. By the mid-1980s, computers, with their rapidly declining prices, upset the ability of constant-dollar aggregates of GDP to stably track real economic growth. After extensive research the BEA introduced superlative formulas into the official computation of GDP (Landefeld and Parker 1995).

But the JHS paper is the first empirical study of growth, since the computer revolution of the late 1990s, to cover the entire U.S. economy and to use a full tool kit of neoclassical techniques. JHS delves, further than earlier published materials, into what must be true about the formal structures of production of the various industries in order to build up aggregate measures that meaningfully summarize the economy. The formal assumptions are certainly strong, even when we employ flexible index number formulas to do all of the aggregations. Potential bias is introduced by chaining together time series of index numbers and of contributions, and so the onehundredth percentage point precision with which JHS present their results may overstate the accuracy. Having said that, I will side with Samuelson and Solow that it is worthwhile to build aggregates, and I will side with the authors on using the flexible formulas to do so.

The authors try to rigorously account for intermediate inputs in real terms. They treat a commodity produced by one industry and consumed by a second industry as an output of the first industry and an input into the second. These intermediate items are then systematically excluded from outputs and inputs in aggregating up measures of total economy produc- 
tivity, using Evsey Domar's (1961) model and superlative index techniques. In order to ensure that this "real production account" is internally consistent, the authors build their real measures up from deflated time series of nominal input-output tables. The only consistent time series of tables available is that produced by the BLS Division of Industry Employment Projections (DIEP). While consistent over time in their structure, these tables are derived from the detailed information in only a single benchmark input-output table (as published by BEA - the 1992 table is the basis for this study). Now the advantage of the flexible aggregation employed by JHS is that it places no a priori restrictions on the structure of production. The DIEP series of tables are constructed by making elegant use of the assumption of fixed input requirements, so the resulting tables do not fully reflect the true flexibility of substitution that the JHS model could accommodate. This was equally a limitation of the production accounting efforts by Gullickson and me (Gullickson and Harper 1999, 2002). The Jorgenson measurement tradition would regard each input-output table as a snapshot of the outcome of the many markets in the dynamic economy. Future efforts at production accounting would best be based on time series of tables built from the actual detailed information in historical benchmark input-output tables. It will be necessary to go back in time and rearrange the information in the tables to be consistent over time, in terms of definitions and categories. The BEA and BLS plan to investigate the feasibility and efficacy of an effort to construct such a real production account.

The JHS paper draws special attention to its measures of labor input and labor "quality," noting that employment of lower-wage workers was unusually high during the late 1990s. This development partially offsets the steady upgrading of the average skills of the labor force, which has been an important source of post-World War II U.S. economic growth, and estimating the size of the contribution is one of the hallmarks of Jorgenson's series of studies. I do want to quibble with the JHS semantics, while emphasizing my approval of the substance of what is done. The term quality conventionally refers to the "characteristics" or to the "degree of excellence" of a member of some specific group. Examples of higher-quality members would be better-trained doctors or better computers. In JHS, labor quality improvements would include employment shifts from janitors to doctors, while capital quality improvements would include investment shifts from office buildings to computers. The BLS $(1983,2002)$ has substituted the term composition change for quality change to avoid any needless connotation about a worker's intrinsic worth. These authors are certainly entitled to define their own terms, but the reader must be careful not to confuse quality in the broad sense of JHS with the more narrow kind of quality exemplified by the increased speed and capacity of computers.

The JHS conclusions emphasize the large role of computers in the late 1990s, a result that reflects large computer quality adjustments (of the 
more narrow type). The last column of table 11.2 compares growth rates (and contributions to growth rates) for 1995-2000 to 1990-95. Labor productivity accelerated by .93 percentage points, and JHS attribute the sources of this as follows: IT capital deepening (information processing equipment and software), .51; IT industry total factor productivity (TFP), .11; all other industries' TFP, .17; all other measured sources of compositional change (including non-IT capital deepening, labor quality, and industry composition effects), .15. Thus, according to the authors, the production and use of IT goods accounts for about two-thirds of the labor productivity speedup in the late 1990s.

The general finding that IT has been important certainly seems plausible. The BLS (2002) also finds a large role for IT. Comparing 1995-2000 to $1990-95$, the BLS found that IT capital deepening accounted for about 0.5 percentage points of a 1.2 percent speedup in private business labor productivity, and my calculations indicate that productivity gains in ITproducing industries accounted for an additional 0.2 points. We all know of many examples of how computers have improved the quality and variety of goods and services available as well as examples of how computers allow workers to accomplish tasks much more efficiently. Both the IT deepening and IT multifactor productivity results are consequences of quality adjustments made by U.S. statistical agencies that use market prices (rather than rental prices) to account for the increased speed and capacity of computers. These adjustments are embedded in the real IT investment data used by JHS.

But the finding that TFP acceleration in all non-IT industries accounts for only .17 percentage points of the labor productivity acceleration is a bit puzzling. It seems to say that non-IT industries have done little more than purchase the ever-better IT equipment and plug it into their production processes. Surely these processes have undergone substantial redesign, and surely the costs, in terms of non-IT inputs, have been substantial. Why don't JHS find more acceleration in non-IT TFP? Two possible explanations deserve emphasis. First, the non-IT redesign costs incurred by downstream industries may constitute intangible investments, and these go unmeasured. If intangible investments accelerated in the late 1990s, we should expect to see an increased contribution to labor productivity by non-IT TFP in the future. This underscores the importance of the goal of this volume-intangible investments are a source of growth that has eluded measurement. Second, statistical agency measurement methods capture more quality change in goods than in services, and there is potentially a bias. The IT quality adjustments, in which most U.S. economists express great confidence, are enormous (persistent double-digit annual rates), while quality adjustments to services are difficult to measure and often neglected. I remain concerned with an issue raised recently by Gullickson and me (Gullickson and Harper 2002). A tilt in the "measurement 
playing field" could lead to a misallocation of industry contributions to aggregate productivity. Quality adjustment deserves continued emphasis and continued scrutiny, because our fundamental understanding of the sources of economic growth is at stake.

\section{References}

Berndt, Ernst R., and Jack E. Triplett, eds. 1990. Fifty years of economic measurement: The jubilee of the Conference on Research in Income and Wealth. Chicago: University of Chicago Press.

Bureau of Labor Statistics (BLS). 1983. Trends in multifactor productivity trends, 1948-81. Bulletin no. 2178. Washington, DC: U.S. Government Printing Office. 2002. Multifactor productivity trends, 1999. News Release no. 02-128. Washington, DC: U.S. Department of Labor, March 12.

Christensen, Laurits R., Dale W. Jorgenson, and Lawrence J. Lau. 1973. Transcendental logarithmic production functions. Review of Economics and Statistics 55 (February): 28-45.

Diewert, W. Erwin. 1976. Exact and superlative index numbers. Journal of Econometrics 4 (4): 115-45.

Domar, Evsey D. 1961. On the measurement of technological change. Economic Journal 71 (284): 709-29.

Gullickson, William, and Michael J. Harper. 1999. Possible measurement bias in aggregate productivity growth. Monthly Labor Review, February, 47-67.

. 2002. Bias in aggregate productivity trends revisited. Monthly Labor Review, February, pp. 32-40.

Jorgenson, Dale, Frank M. Gollop, and Barbara M. Fraumeni. 1987. Productivity and U.S. economic growth. Cambridge, MA: Harvard University Press.

Jorgenson, Dale, and Zvi Griliches. 1967. The explanation of productivity change. Review of Economic Studies 34 (3): 249-82.

Landefeld, J. Steven, and Robert P. Parker. 1995. Preview of the comprehensive revision of the national income and product accounts: BEA's new featured measures of output and prices. Survey of Current Business, July, pp. 31-38.

Solow, Robert M. 1957. Technical change and the aggregate production function. Review of Economics and Statistics 39 (3): 312-20. 